\title{
Architecture and Hydraulic Relevance of Brittle Fault Zones in the Metamorphic Basement of the Pannonian Basin
}

Töréses vetözónák szerkezete és hidraulikai jelentösége a Pannon-medence metamorf aljzatában

Ph.D. Thesis

Author:

László Molnár

Supervisors:

Dr. Tivadar M. Tóth

Dr. Félix Schubert

University of Szeged

Faculty of Science and Informatics

Department of Mineralogy, Petrology and Geochemistry 


\section{Table of Contents}

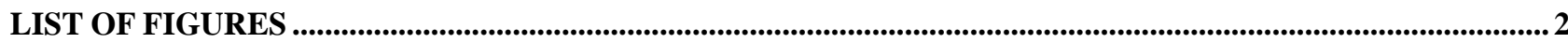

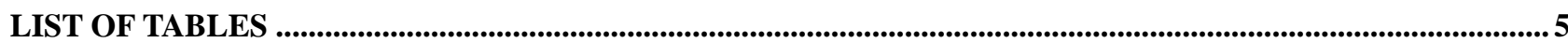

CHAPTER I.: INTRODUCTION ...............................................................................................................................

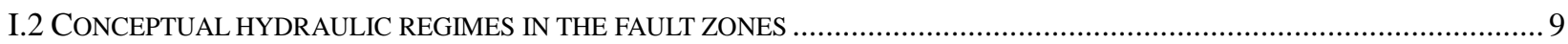

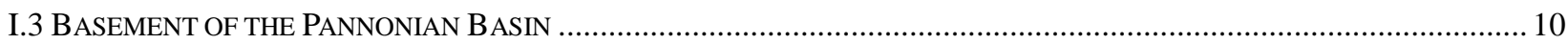

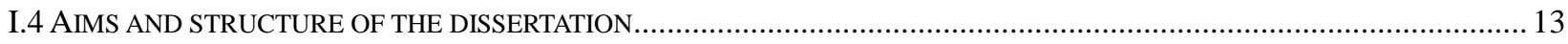

CHAPTER II.: STATISTICAL CHARACTERIZATION OF BRITTLE AND SEMI-BRITTLE FAULT ROCKS:

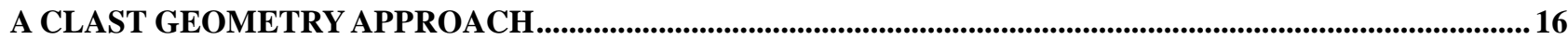

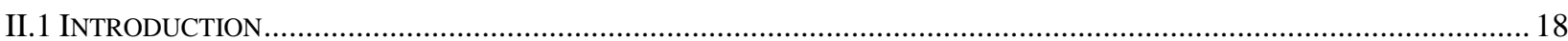

II.1.1 Brittle fault zones and their flow properties ................................................................................. 18

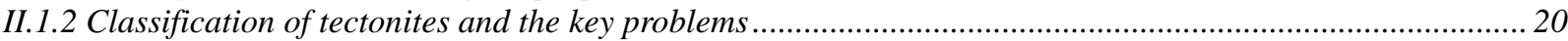

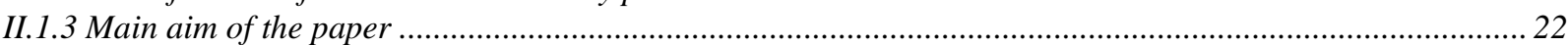

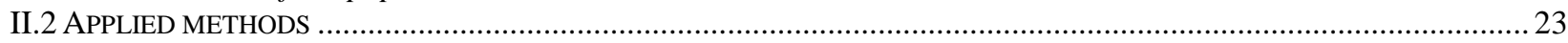

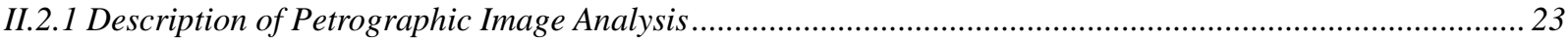

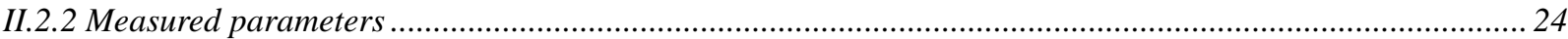

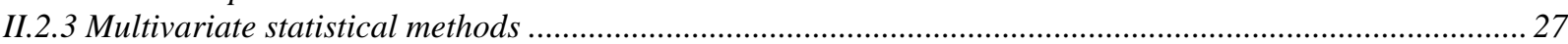

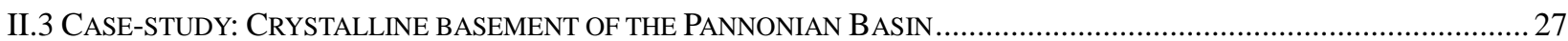

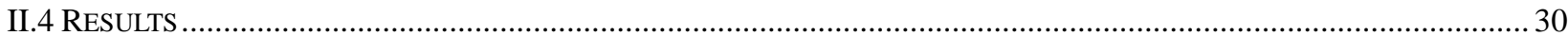

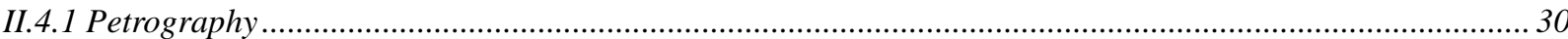

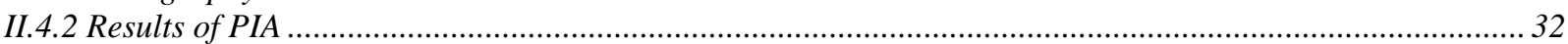

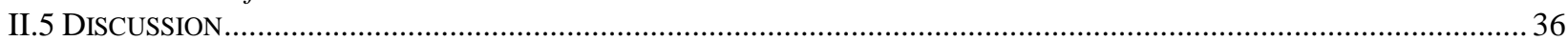

II.5.1 Discrimination of tectonites based on geometric parameters ……………………................................... 36

II.5.2 Possible effects of clast geometry on hydraulic properties.................................................................... 47

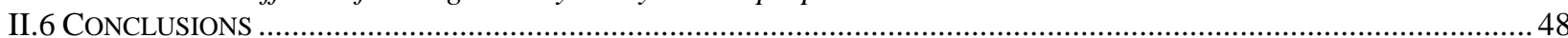

CHAPTER III.: INTEGRATED PETROGRAPHIC - ROCK MECHANIC BORECORE STUDY FROM THE METAMORPHIC BASEMENT OF THE PANNONIAN BASIN, HUNGARY .........................................................50

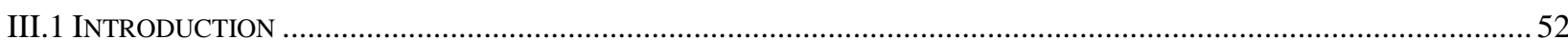

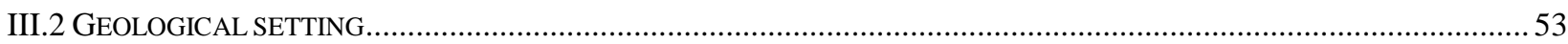

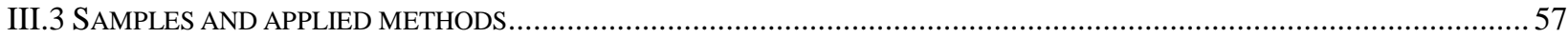

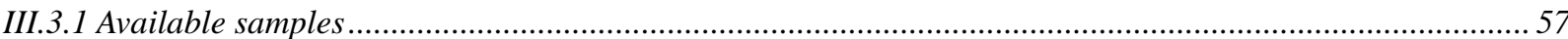

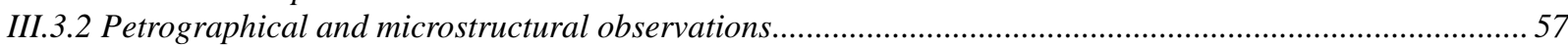

III.3.3 Description of Petrographic Image Analysis (PIA) _................................................................................. 57

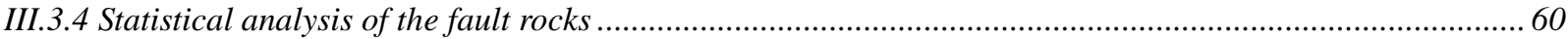

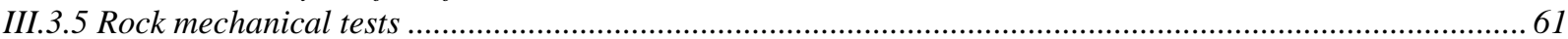

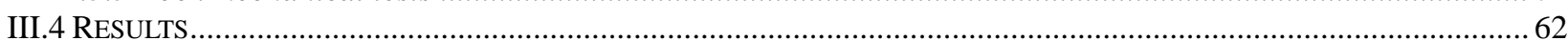

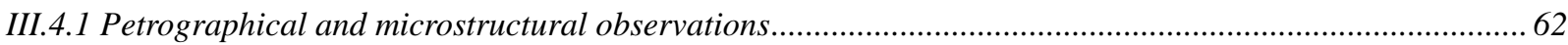

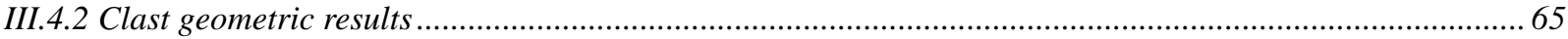

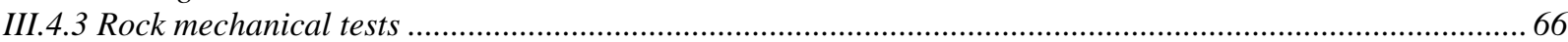

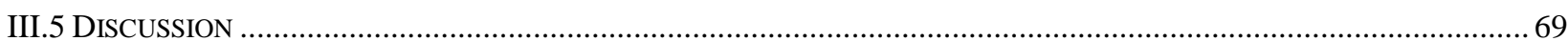

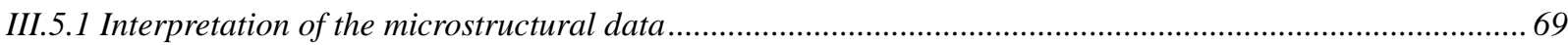

III.5.2 Rock mechanical properties of the fault rocks.................................................................................... 72

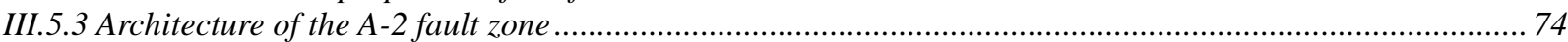

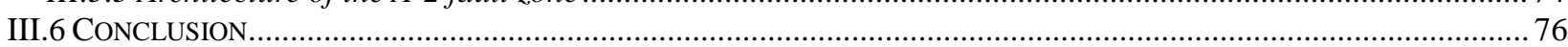

CHAPTER IV.: A FAULT-CONTROLLED FRACTURED METAMORPHIC RESERVOIR IN THE PANNONIAN BASIN, SE HUNGARY .................................................................................................................. 77

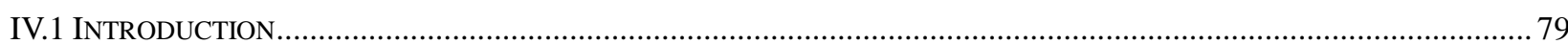

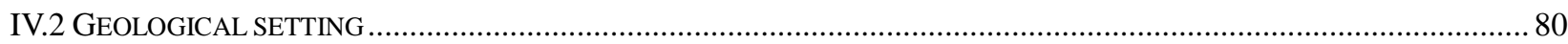

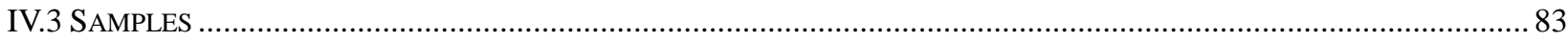

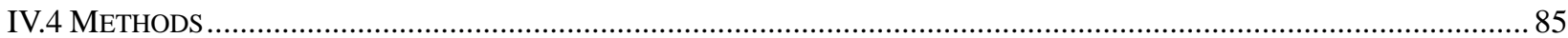

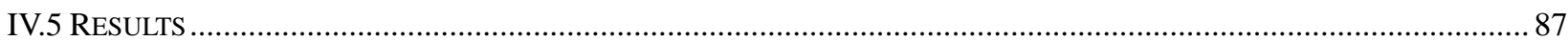

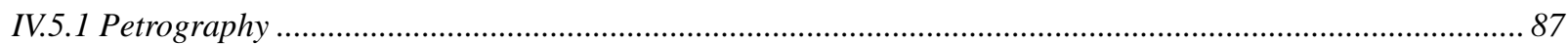

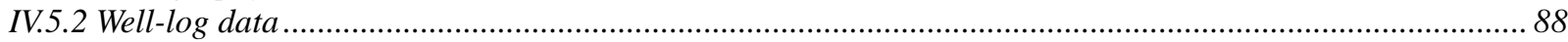

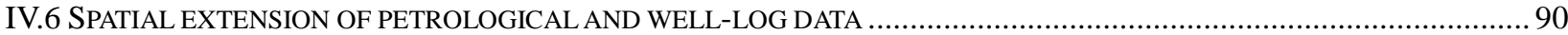

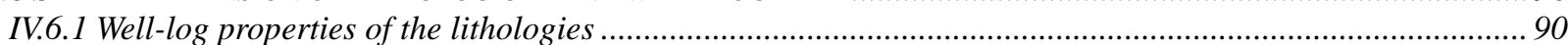




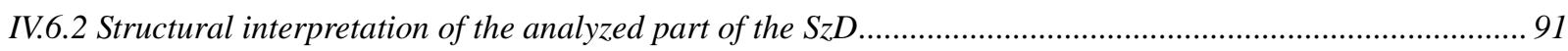

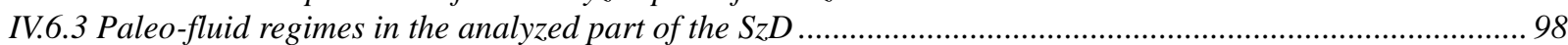

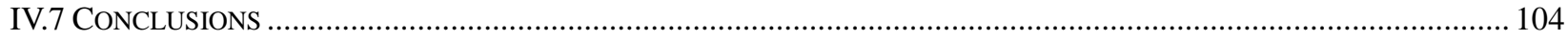

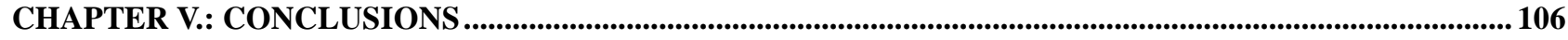

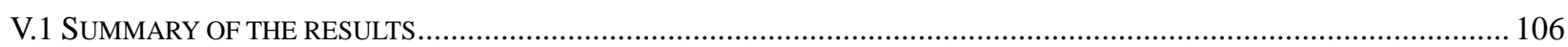

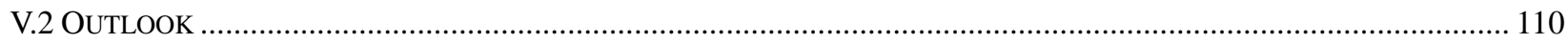

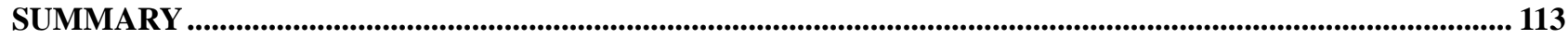

ÖSSZEFOGLALÁS

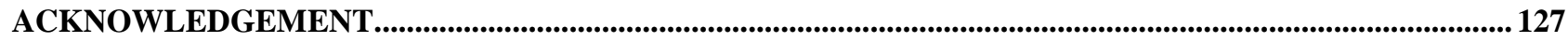

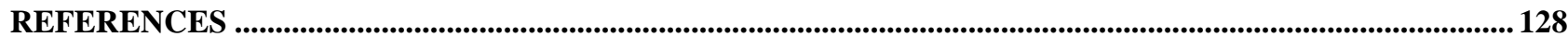

\section{List of Figures}

Figure I.1.: Fault sealing mechanisms by Moeller-Pedersen and Koestler (1997) and Fossen (2010). Diagenetic processes were separated due to their distinct mechanical effects: cementation is often accompanied with fault hardening, while the weathering and authegenic clay growth result fault softening.

Table I.1.: Summary of fault zones typical hydrodynamic behaviour, according to Caine et al. (1996), Evans et al. (1997) and Manzocchi et al. (2010).....

Figure I.2.: Elements of the petroleum system in the Pannonian Basin. The source rocks and the reservoir formations are mainly Paleogene and Neogene in age, subordinate Mesozoic formations. In the course of the migration the Paleozoic crystalline basement also takes part in the accumulation. After Horváth and Tari (1999). Legend: 1 -Paleozoic formations, 2 - Mesozoic formations, 3 - Paleogene and Neogene formations, 4 - Quaternary formations, 5 - source rocks, 6 - migration pathways of oil, 7 - migration pathways of gas, 8 - reservoirs in the basin, 9 - reservoirs in the basement.

Figure II.1: a: Core-sample from metamorphic basement of the Pannonian Basin. b: Scanned core photo. c: Clasts selected for the measurements, drawn one-by-one in Adobe Photoshop. d: Separation of clasts from the matrix for the measurements in ImageJ. Arrows indicate the long axis orientation of the core.

26

Figure II.2: Location of the Szeghalom Dome in the Pannonian Basin and their geological environment. The contoured map indicates the depth to the basement in meters. The figure (d) marks the depth interval of the investigated samples in a schematic north to south cross-section of the area.

Figure II.3: a, b: Coarse fault breccia, containing rock (gneiss) fragments (a: in plane polarized light, b: in crosspolarized light). c, d: Oriented, elongated ribbons of clasts in foliated cataclastic fabric (c: in plane polarized light,d: in cross-polarized light). e,f: Layers of comminuted gouge contains mainly crushed mono-crystals (e: in plane polarized light, f: in cross-polarized light). The scale bars are 500 micrometer.

Figure II.4: Results of all geometric parameters. Samples are arranged in order of increasing disintegration. The degree of disintegration was estimated from the microstructural observations. The results of figure (f) are separated into figure (g) and (h), due to their strongly different values.

Figure II.5: a: The PSD values of different lithologies show rock fragments $\rightarrow$ polycrystalline quartz $\rightarrow$ feldspar $\rightarrow$ monocrystalline quartz order of fragmentation. Note: extreme grain sizes close to the lower and upper limit are neglected, as these clasts misfit at the scale of observation. b.: Comparison of PSD values of meso- and 
micro-scale samples from similar depth-interval. The micro-scale samples show constantly stronger fragmentation.

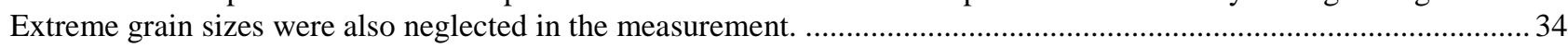

Figure II.6: Histograms of the analysed geometric parameters.

Figure II.7: Scatterplot matrix of the variable's data according to Table II.2. In the lower part of the matrix the correlations of a variable with the other parameters are plotted against the similar data of other parameters. In the upper part, these are displayed in the case of the covariation. In the diagonal plots, the correlations and the covariances were plotted for each parameter.

Figure II.8: a: Histograms of discriminant functions $\mathrm{D}(1,2),(2,3),(1,3)$. In $\mathrm{D}(1,2)$ group 3 is close to group 2 , in $\mathrm{D}(2,3)$ group 1 to group 2, while in $\mathrm{D}(1,3)$ group 2 to group 3. b: The plot of D1 and D2 discriminant functions, showing clear separation of tectonite types, implying a proper classification of these groups by the combination of their geometric parameters. c: The two dimensional projection of multidimensional-scaling. The vectors indicate the direction and strength of the parameters in the multidimensional space. The groups of breccias and cataclasites reflect relatively similar tendencies, meaning they are determined by the same geometric parameters. The fault gouges have significantly different characteristics in their geometric properties.

Figure II.9: Scree plot of the multidimensional-scaling. The plot of the stress values and the dimensions imply that the addition of the first four dimension (with PSD, Angle, AR, and Circ parameters) add significantly to the model. .45

Figure II.10: Possible evolution of different tectonites by their geometric parameters. Process 1: initial fragmentation of the breccias, 2: onset of cataclastic flow and comminution, 3: gouge forming by chipping, abrasion and rounding of particles and intensive grain size reduction. Numbers denote the extreme PSD values for each group.

Figure III.1: Topographic map of the Pre-Neogene basement of the eastern part of the Pannonian Basin and the distribution of the basement highs (shaded). Isolines denote depth below the present surface in meters. Inset: Location of the studied well in the Alpine-Carpathian-Pannonian System. A - Alps, BM - Bohemian Massif, C - Carpathians, D - Dinarides, PB - Pannonian Basin

Figure III.2: a: Detailed sub-surface topography of Mezősas-Furta Dome. Dots mark the productive wells of the field, while dashed line indicates the assumed location of the main hydrocarbon accumulation. Isolines denote depth below the present surface in meters. b: Schematic vertical section of the investigated well and borecores evaluated in this study. The grey rectangles indicate the location of the samples.

Figure III.3: Polished surface of a borecore from well A-2 (sample M1) and the clasts selected for the measurements, drawn one-by-one in Adobe Photoshop. The diameter of the borecore is 6.5 centimeter. ..... .58

Figure III.4: Photomicrographs representing characteristic fault rock textures from the samples of A-2. a: Typical cataclastic texture, which is the most frequent structure of the samples with fragmented and rotated particles (sample M5). b: Strongly deformed domains between the centimeter-scale particles (sample M6). c: Planes of intensified deformation denoted by strongly fragmented cataclastic texture among relatively less deformed coarse grains (sample M4). d: Dilational domain with a weakly disaggregated texture, indicating a characteristic fault breccia texture (sample M2). e: Strongly foliated fault gouge plane with restricted distribution. The foliation is defined by the phyllosilicate flakes (sample M8). f: Granular fault gouge, which is regarded as the location of the largest fault displacement. Note the extremely high matrix ratio, which indicate the comminution of the clasts (sample M10). The scale bars are $500 \mu \mathrm{m}$ long.

Figure III.5: a: Illustrated plot of the uniaxial compressive strength and crack propagation stress level, which defined the onset of stable fracture growth at the $83 \%$ of the longterm rock strength, which generally agree with $85 \%$ value of the general ISRM (2006) suggestions. b: Plot of uniaxial compressive strength and Young modulus reveals a quite strong increasing trend of the measured rock mechanical features, while only two of the samples (M4 and M5) do not fit to this trend. c: The characteristic stress-stain curves from A-2. Sample M1 a strongly rigid nature with low uniaxial compressive strength. M4 represent relatively higher $\sigma_{\mathrm{c}}$ and necessary work for the failure of the sample, indicating a strain-hardening nature. In contrast, the stress-strain curve of M10 reveals its strongly plastic and inelastic nature. These rock-mechanical features follow each other with increasing depth. d: Plot of measured Poisson rates versus the brittleness indexes with the quite clear separation of the samples derived from distinct fault components: the damage zone (M1-3), the transition zone (M4-6) and the fault core (M7-10).

Figure III.6: Illustration of measured fault rock samples from well A-2 based on their calculated D1 - D2 values (detailed in Chapter II.) with characteristic values for each fault component. The reference data of the classification derived from the adjacent Szeghalom Dome are also displayed..... 
Figure III.7: Characteristic grain size distributions from the three main petrographic zones. These domains reflect higher PSD values with the stronger observed deformation. The coarse grained brecciated samples have relatively lower PSD dimensions $(<1.3)$, while, following the transitional values of the cataclasites, samples from the fault gouge-rich zones own the highest PSD dimensions (> 1.6). This latter group can be characterised with increasing comminution and particle size reduction with intensive gouge formation and strain localization.

Figure III.8: Schematic composition of the fault zone according to the integrated results of the petrographic and rockmechanical investigations. For each fault components, their most characteristic features are displayed with the $\sigma_{\mathrm{c}}$ data. Increasing $\sigma_{\mathrm{c}}$ data towards the undeformed wall rock is presumed due to their less deformed nature. Literature data on the architecture of brittle fault zones suggest the downward continuation of the deformed horizons. Thicknesses of the fault units are not to scale.

Figure IV.1: a: Location of the Szeghalom Dome in the Pannonian Basin and its geological environment. b: Szeghalom Dome in the eastern part of the Pannonian Basin with the adjacent sub-basins and elevated basement highs. c: Locations of the sampled wells in the central part of the SzD. The contour map indicates the depth to the basement in meters. .... 81

Figure IV.2: a, b: Coarse fault breccia with gneissic origin $(1 \mathrm{~N},+\mathrm{N})$ (well A-180). c, d: Crushed, slightly elongated clasts in cataclastic fabric $(1 \mathrm{~N},+\mathrm{N})($ well A-180). e, f: Fault gouge clasts composed of crushed mono-crystals $(1 \mathrm{~N},+\mathrm{N})$ (well A-180). The scale bars are $500 \mu \mathrm{m}$ long.

Figure IV.3: a: Detailed lithologic composition of the fault zone in well A-180 with the calculated D(1-2) values. The fault gouge-bearing intervals at 1917, 1922 and 1926 meters indicate the locations of the largest displacements. b: Theoretical workflow for the determination of the lithologic architecture in the analyzed wells. Functions $\mathrm{D}(3)$ and $\mathrm{D}(4)$ are applied only when $\mathrm{D}(1-2)$ defines the sample as a tectonite. c, d: Representative well-log sections for undeformed (c) and deformed (d) depth intervals, which are verified with the borecore data.

Figure IV.4: a: Separation of the deformed and undeformed depth intervals using the scores of the calculated D(1-2) function. The most important well-log parameters used to discriminate the intervals were the natural gamma, density and resistivity values. b: Discrimination of different fault rock types with the calculated D3 - D4 functions, which are mainly based on the compensated neutron porosity, resistivity, density and natural gamma log values.

Figure IV.5: Spatial variations of the most important well-log parameters for an idealized fault zone. The darker colors indicate greater parameter values. According to this interpretation, the deformation is often associated with decreasing density and resistivity towards the core zone. The most significant porosity enhancement develops in the weaker fragmented and brecciated zones.

Figure IV.6: The interpreted lithologic compositions of the analyzed wells. The dashed line indicates the observed lowangle fault surfaces. The wells form two triplets, including a northern and a southern block. Along with the lithologic composition, the calculated $\mathrm{D}(1-2)$ values are also illustrated along the 1D section of the wells.

Figure IV.7: Basement map of the Szeghalom High with the major interpreted structural elements. The contour map indicates depth to the basement in meters. The Cretaceous nappe structures were overprinted by complex Neogene normal faulting. Note that members of the AG group dominate at the top of the basement. For details of transect A-A', see Figure IV.8.

Figure IV.8: West-northwest - east-southeast cross section of the Szeghalom Dome. The dashed lines indicate the separate paleo-fluid systems based on previous fluid inclusion results (Schubert et al., 2007). The Late Cretaceous nappe surfaces were cut by high angle Neogene normal faults. Significant storage capacity in the basement is exclusively related to amphibolite bodies in the AG group. The composition of the basement is unknown below the well A-22. The horizontal components of the cross section are not to scale. .96

Figure IV.9: The permeability architecture of a thrust fault zone according to Evans et al. (1997). The highest permeability values occur parallel to the fault plane and parallel to the slip direction ( $\left.\mathrm{K}_{(\mathrm{par}))}\right)$, and the lowest permeability values occur perpendicular to both the fault plane and the slip direction $\left(\mathrm{K}_{(\mathrm{per})}\right)$. Transitional permeability values occur parallel to the fault plane and perpendicular to the slip direction $\left(\mathrm{K}_{(\mathrm{par} 2)}\right)$. These results indicate that the fault zone has a significant $\left(10^{4}\right)$ permeability anisotropy ratio.

Figure IV.10: Schematic model of the geodynamic and hydrodynamic evolution of the Szeghalom Dome. 1: Coastal conglomerate (Békés Formation), 2: Basal clay marl, which forms a local aquitard (Endrőd Formation), 3: Turbiditerich sediments (Szolnok Formation), 4: Delta front sediments (Algyö Formation), 5: Main brittle fault zones, 6: Regional fluid flow system. a: Variscan multi-stage metamorphism of the lithologic groups at diverse pressure and temperature conditions. b: Late Cretaceous nappe tectonics along low-angle thrust faults, which juxtaposed the AG, SG 
and OG lithologic groups. Deformation took place at shallow depths and with unknown overlying rocks. c: Middle Miocene (Badenian) exhumation of the SzD with the formation of a series of high-angle normal faults and the deposition of Pannonian clastic sediments. d: Recent hydraulic system of the SzD following Late Miocene subsidence of the area with significant overpressure under the local aquitard (Endröd Formation) and the evolution of the "chimney structure". The cross sections are not to scale.

\section{List of Tables}

Table II.1: Classification of fault rock-series, adapted from Sibson (1977, 1986), Laznicka (1988), Tanaka (1992) and Woodcock and Mort (2008).

Table II.2: Covariance and correlation matrices of the analysed geometric parameters.

Table II.3: Details of significance test for the discriminant functions with their roots (eigenvalues) and Wilks' lambdas for the pairwise functions (a) and D1-2 (b). In D1-2 both of the functions add significantly to the classification.

Table III.1: Published grain size distribution data of brittle fault rocks, based on the results of Sammis et al.(1987), Blenkinsop (1991), Storti et al (2003), Keulen et al. (2007).

Table III.2: Measured clast-geometric data (a) and mechanical constants (b) of the investigated samples. 66

Table IV.1: The available borecores with their intervals, in meters below sea level. 


\section{Chapter I.: Introduction}

\section{I.1 Brittle Fault Zones}

Brittle fault zones are lithologically strongly heterogeneous structural elements, which significantly affect the hydrogeological systems in the upper part of the Earth's crust. Penetration depth of the meteoric water can reach even 10-15 km (Caine et al., 1996) and faults, as a result of their barrier, conduit, or mixed conduit/barrier nature strongly govern the local fluid flow from microscale range up to reservoir-scale. Structural and hydraulic features of the fault zones may reflect an intense temporal and spatial variation. While, for instance juvenile fault zones may have permeable behavior, they later may become a barrier in their mature stage. The main fault components, detailed by Caine (1996) or Evans (1997) are the "fault core" and the associated "damage zone".

Fault core can be defined as the structural, lithological, and morphological part of a fault zone where most of the displacement is accommodated and the original texture of the protolith might have completely erased. Fault cores may include tectonites with diverse degree of disintegration e.g., slip surfaces (Caine et al., 1996), clay-rich gouge (Engelder, 1974) or locally breccia and cataclasite zones (Chester et al., 1985). Nevertheless, these components usually act as barriers to the fluid flow due to their significant permeability reduction (Storti et al., 2007).

In contrast, the damage zone suggests a structural transition from the fault core towards the undeformed wall rock, but it may hydrodynamically reflect a considerable transmissibility enhancement. Damage zone mainly comprises quite heterogeneous subsidiary components as secondary faults, fractures, veins and in some cases, slightly fragmented, coarse breccias, which result a quite anisotropic permeability structure (Caine et al., 1996). 
These components are always surrounded by the undeformed protolith, where fault-related textures with their effect on the permeability are absent. Moreover, rheologic properties set back to the original characteristics of the wall-rock. The transition between the damage zone and fault core is usually sharp, contrary to the damage zone to protolith boundary, which is prevalently gradual (Caine et al., 1996).

The width, spatial arrangement and the geometry of each unit are defined predominantly by the lithology, tectonic setting and the stress conditions of the fault formation. From the aspect of the lithology, it can be accepted as a general rule that "the faults tend to increase permeability in nonporous rocks, while they commonly reduce permeability in porous systems" (Fossen, 2010). Beside the previously mentioned components of the theoretic faults, there are numerous factors that can affect fluid flow in different ways. According to Moeller-Pedersen and Koestler (1997) or Fossen (2010) the most important processes that control the fault zone permeability are the following (Fig. I.1):

- Juxtaposed lithologies: The lithological contact relations along a fault are essential, their possible effects were described in detail by Allan (1989). The scenario, where permeable (e.g. sandstone) is completely juxtaposed against impermeable (e.g. shale) can be defined as "juxtaposition seal", and the fault is sealing, regardless of its properties. In the case, when sand is juxtaposed against sand, the transmissibility of the fault is controlled by its physical properties and can be referred as "selfjuxtaposed seal". If clay or shale (over $40 \%$ phyllosillicate content) smeared between the sand layers can be regarded as "shale smear seal".

- Diagenetic effects: Syn- or post-deformational diagenetic processes can strongly alter the mechanical and petrophysical properties of the fault rock, which are notable reservoir problem at temperatures above $90{ }^{\circ} \mathrm{C}(\sim 3 \mathrm{~km})$. Diagenetic processes can result fault hardening (e.g. quartz cementation) or fault softening (e.g. growth of authigenic clay minerals), depending on the 
physical-chemical details of the reactions (Wintsch et al., 1995). The increasing surface of the reactants in the fault zones, derived from fragmentation, easily enhance the fluid infiltration along the fault zones and the fluid-rock interaction.

- Cataclasis or fault gouge formation: Cataclasis in the fault core reduces grain size and therefore reduces porosity and permeability. This process is promoted by deep $(>1 \mathrm{~km})$ burial depths, low phyllosilicate content ( $<15 \%$ clay or phyllosilicate proportion), well-sorted grains and low porefluid pressure (Fossen et al., 2007). The fault gouge formation is a more advanced fragmentation process, where fault rock loses its cohesion (Engelder, 1974) and a matrix-dominated micro-texture evolves. Fossen (2010) showed that the thickness of the gouge zone of brittle faults increases linearly with total slip. The evolution of these fault rocks is dominated by grain fracturing and occurs in deformation bands, most frequently in the fault core. The fine-grained nature of clastic sedimentary rocks results in the evolution of special fault rock types, for example the (framework) phyllosilicate bands (with phyllosillicate content between 15-40\%), which effectively stop fluid flow or in contrast, the disaggregation zones (deformation bands in poorly consolidated lithologies with phyllosillicate content below 15\%) favor to form conduit zones (Fossen et al., 2007).

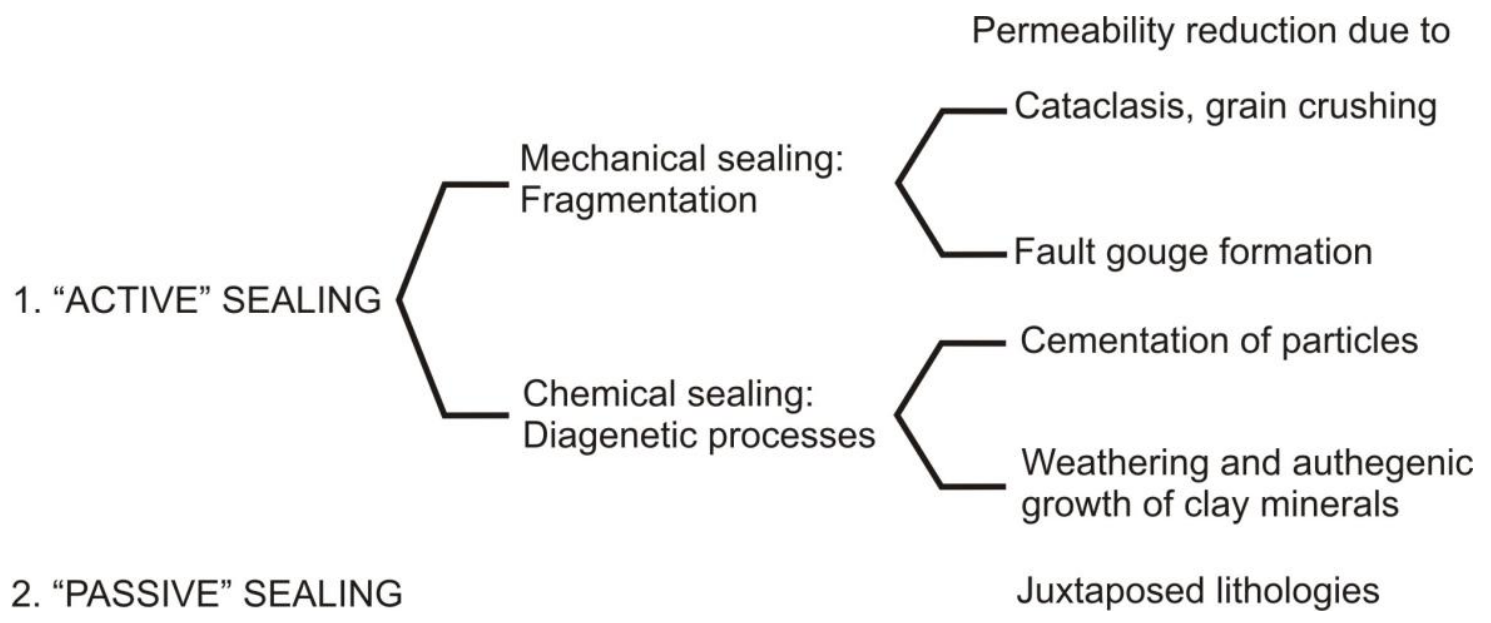

Figure I.1.: Fault sealing mechanisms by Moeller-Pedersen and Koestler (1997) and Fossen (2010).

Diagenetic processes were separated due to their distinct mechanical effects: cementation is often 
accompanied with fault hardening, while the weathering and authegenic clay growth result fault softening.

\section{I.2 Conceptual hydraulic regimes in the fault zones}

The fundamental works of Caine et al. (1996), Evans et al. (1996), Storti et al. (2007), Lonergan et al.(2007) or Manzocchi et al. (2010) defined four characteristic fault zone types, based on their structure and permeability. The so-called "localized conduit", "distributed conduit", "localized barrier" and "combined conduit-barrier" are the typical fluid flow scenarios (Table I.1.), where fault transmissibility is strongly influenced by the nature of the damage zone, but mostly by the thickness, geometry and structure of the fault core. These presented fault zone types more or less reflect an increasing degree of total displacement, as larger off-sets presume the evolution of more complex fault architectures.

\begin{tabular}{|c|c|c|c|c|}
\hline Permeability structure & Architecture & Fault core & Damage zone & $\begin{array}{l}\text { Application in reservoir scale } \\
\text { and flow models }\end{array}$ \\
\hline Localized conduit & Localized deformation along discrete planes & Poorly developed or absent & Poorly developed or absent & Discrete, conduit planes \\
\hline Distributed conduit & $\begin{array}{l}\text { Distributed deformation along dense } \\
\text { fracture and fault planes }\end{array}$ & $\begin{array}{l}\text { Absent or poorly developed as } \\
\text { narrow, discontinous planes }\end{array}$ & $\begin{array}{l}\text { Wide, well-developed } \\
\text { deformation planes with dense } \\
\text { fracture network }\end{array}$ & Equivalent porous medium \\
\hline Localized barrier & Localized deformation with cataclasis & $\begin{array}{l}\text { Well developed fault core with } \\
\text { cataclasis }\end{array}$ & Poorly developed or absent & $\begin{array}{l}\begin{array}{l}\text { Aquitard (fault core) } \\
\text { permeability within higher } \\
\text { protolith) }\end{array} \text { aquifer } \\
\text { (undeformed }\end{array}$ \\
\hline Combined conduit-barrier & $\begin{array}{l}\text { Deformation with localized cataclastic zone } \\
\text { and distributed damage zone }\end{array}$ & $\begin{array}{l}\text { Well developed fault core with } \\
\text { cataclasis }\end{array}$ & $\begin{array}{l}\text { Wide, } \quad \text { well-developed } \\
\text { deformation planes with dense } \\
\text { fracture network }\end{array}$ & $\begin{array}{l}\text { Aquitard (fault core) closed between } \\
\text { aquifers (damage zones) with Kmax } \\
\text { within and Kmin normal to the plane of } \\
\text { the fault zone }\end{array}$ \\
\hline
\end{tabular}

Table I.1.: Summary of fault zones typical hydrodynamic behaviour, according to Caine et al. (1996),

Evans et al. (1997) and Manzocchi et al. (2010).

The "localized conduit" is a strongly localized fault zone type, where the displacement occurs along a single surface. There is an absent or only a weakly developed fault core and only a 
few subsidiary structures occur in the damage zone. From modeling aspects, these planes can be most properly represented as a separated, porous plane for the fluid flow in a discrete fracture network.

The "distributed conduit" member indicates deformational systems, where the displacement accommodated in a series of slip surfaces or shear fractures, however, without the formation of a distributed fault core. As these planes of the displacement own a conduit behavior for the fluid flow, this fault type can be interpreted as equivalent porous media with estimated fracture permeability for a given volume.

The "localized barrier" type fault zones include a relatively well-developed fault core, where the intense fragmentation and cataclasis is frequent, but there is only a thin damage zone. These fault systems can be modeled with an aquitard (fault core) within an aquifer (undeformed protolith).

Finally, "combined conduit-barrier" fault zones represent well-developed, but often localized fault core with cataclasis and fault gouge formation, which is encompassed by the damage zone components. In this sense, aquitard (fault core) developes closed between aquifers (damage zones) with relatively high permeability parallel to the fault zone and low permeability perpendicular to it, indicating strong permeability anisotropy. These fault zones can be modeled most adequately as a dual porosity system and often contain a compartmentalized hydraulic regime, due to the geometric continuity of the impermeable fault cores.

\section{I.3 Basement of the Pannonian Basin}

In the course of recent study, hydrogeologic effects of the fault zones are investigated on the example of the metamorphic basement of the Pannonian Basin (PB), which is surrounded by the Alpine-Carpathian-Dinaric orogenic belt. As a result of widespread subsidence during the late Tertiary ages, the PB was filled up by thick layers of sediments (from $500 \mathrm{~m}$ to $7000 \mathrm{~m}$ ) of middle 
Miocene synrift to the late Miocene-Pliocene postrift origin. According to Teleki et al. (1994), the sandstones with Pannonian age are the reservoir rocks of most of the currently explored hydrocarbon accumulations of the PB. Less, but still important reservoirs are the Paleogene clastic sedimentary rocks (in Szolnok flysch trough or the North Hungarian Paleogene epicontinental basin) or the Mesosoic fractured carbonates (Zala Basin, e.g., Nagylengyel field) with wide spectra of age, lithology and possible source rocks (Horváth and Tari, 1999) (Fig. I.2).
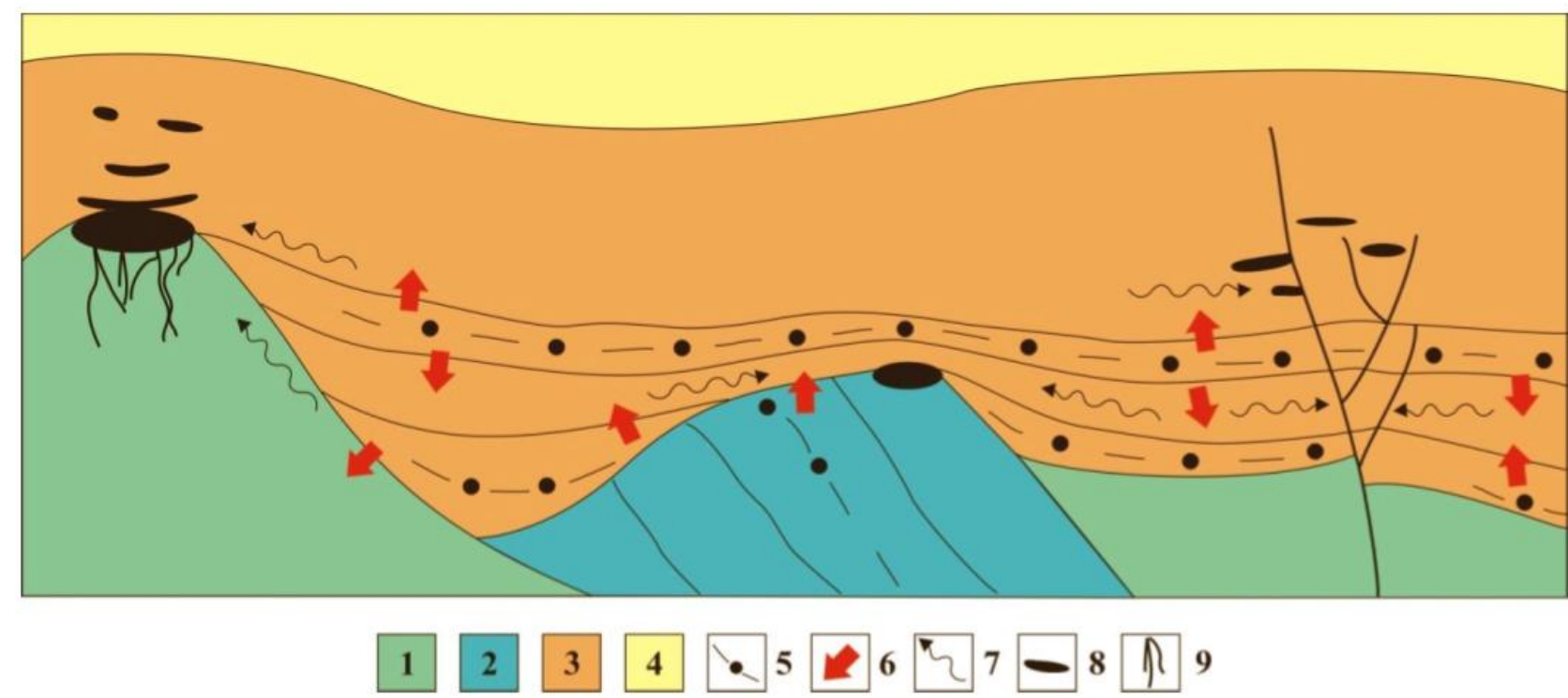

Figure I.2.: Elements of the petroleum system in the Pannonian Basin. The source rocks and the reservoir formations are mainly Paleogene and Neogene in age, subordinate Mesozoic formations. In the course of the migration the Paleozoic crystalline basement also takes part in the accumulation. After Horváth and Tari (1999). Legend: 1 -Paleozoic formations, 2 - Mesozoic formations, 3 - Paleogene and Neogene formations, 4 - Quaternary formations, 5 - source rocks, 6 - migration pathways of oil, 7 - migration pathways of gas, 8 - reservoirs in the basin, 9 - reservoirs in the basement.

As subdominant accumulations, Paleozoic crystalline rocks provided about 20 smaller fields in the southern part of PB (Horváth and Tari, 1999), mainly as relatively uplifted basement domains. The traditional and most frequent explanation for the formation of these pools is the lateral migration of hydrocarbons out of the mature, Neogene source rocks into the fracture system 
of the metamorphic highs. It is also a long-standing statement that the Pannonian reservoirs usually form curved arches over the relatively uplifted the basement highs (Dank, 1988). Békés Basin, the deepest sub-basin of PB, is bordered to north by several Paleozoic highs, which contain significant amount of accumulated petroleum (e.g., Dévaványa, Endrőd, Szeghalom, Mezősas-Furta, Sarkadkeresztúr fields). These basement highs are rather heterogeneous mosaic of blocks concerning their lithological composition and developed through a series of complicated tectonics following the Variscan multi-phase metamorphism (e.g., Kovács et al., 2000). The pervasive deformation with predominantly Alpine or Neogene ages at many places associated with notable porosity enhancement, resulting in permeable intervals not exclusively on the widely known weathered/altered surface of the basement, but also over hundred meter beneath the top of the basin highs. All these findings with the recent results (M. Tóth, 2008, Czauner and Mádl-Szőnyi, 2013) indicate hydrogeologic relevance of the brittle fault zones and the fractured metamorphic host rock in the petroleum system of the basement.

However, the decipherment of these structures and the prediction of potential traps or migration pathways within the basement are rather problematic due to numerous causes. The Paleozoic basement of Tisza unit in the PB (Szederkényi et al., 1991) is predominantly covered by sediments of a thickness of up to 6000 metres, so their lithology and the structure can not be investigated at outcrop scale, which increases the importance of the available drilling documents, borecores, well-logs and seismic sections. This situation is often further complicated by the outdated seismic imaging techniques which were applied at the exploration stage of these fields, mostly in the 1970s and 1980s. As these seismic survey mainly focused on the Neogene clastic sediments in the overlie or only to the weathered top of the basement, the interior of the Palaeozoic basement remained essentially undiscovered, due to the sporadic and hardly interpretable reflectors. Only few attempts were made to locally define its main structure elements via the usage of sophisticated seismic methods, however, often quite high efficiency (Albu and Pápa, 1992, M. Tóth et al., 2009). Nevertheless, these studies could not define the quite important subseismic fault or 
fracture generations (Ben-Zion and Sammis, 2003), which undoubtedly have a crucial role in the flow attributes of the basement highs. In the absence of these data, the evaluation requires a profound borecore, well-log or well-test analysis and correlation. Numerous, thoroughly explored basement reservoir with similar properties can point out some possible methods for the evaluation of the metamorphic highs in the PB (e.g. Gulf of Suez: Egypt, Salah and Alsharhan, 1997, La Paz Field, Maracaibo Basin, Venezuela: Nelson, 2001, Travis Peak Field, East Texas basin, U.S.A.: Becker et al. 2010, Sa'yun Masila Basin, Yemen: Murray and Montgomery, 2012, White Tiger field, Vietnam: Cuong and Warren, 2009).

In recent study, the situation is similar, as described above: numerous wells were drilled on the examined Szeghalom Dome $(\mathrm{SzD})$ and the adjacent crystalline highs north to the Békés Basin, however, the number of borecores and well logs are limited and there is no available seismic dataset from the basement. Further valuable information is provided by industrial reports and well-test interpretations. Lithological composition and metamorphic pressure-temperature-time pathway for SzD were summarized by M. Tóth (2008), with the most characteristic lithologies (diverse types of gneisses, amphibolite and micro-granite) and determined the conceptual lithological framework model of the highs. The post-metamorphic fluid and fracture network evolution was described by Juhász et al. (2002) and Schubert et al. (2007), which results comprise the possible date of the petroleum migration and the details of hydraulic connection with the adjacent or overlying sedimentary rocks. Although these studies revealed the importance of the brittle fault zones in the juxtaposition of the diverse metamorphic blocks and subsequent fluid migration, definition of their spatial arrangement have not been achieved, yet.

\section{I.4 Aims and structure of the dissertation}

The forthcoming sections are a selection of published and submitted papers about the brittle 
fault zones and their role in basement hydrocarbon reservoirs of PB. The main aim of this study was to reveal the manners of the brittle deformation, at least in metamorphic lithology, to define the main mechanisms and the internal structure of fault zones. In addition, the unraveling of rock mechanical, rheologic properties of the tectonites was also a target of this work. Finally, the relevance of the post-metamorphic brittle deformation will be introduced on a selected part of the Szeghalom basement reservoir, which also comprises a possible method for the spatial extension of the 1D lithologic data. These outcomes are possibly suitable for defining the most important tectonic events of the area and explain their role in the fluid history or the recent petroleum system.

Following this brief introduction (Chapter I.), each part of the dissertation represents a different stage of the research. Chapter II. presents a microstructural analysis of the tectonites on the example of a fault zone with relatively high borecore recovery from the Szeghalom Dome. As a part of this, measurement of the shape/size parameters of the particles derived from the brittle deformation were achieved, both in borecore and thin section scale. The obtained huge database made their statistical processing possible with purpose to separate the distinct fault rocks and to reveal the prevalent brittle deformational mechanisms in diverse stages of fragmentation.

In Chapter III. an attempt was taken to define the rock mechanical attributes of the fault rocks, as an opportunity were provided to analyze their behavior during series of uniaxial compressive tests on the adjacent Mezősas-Furta Dome, in a similar lithological environment as observed in the SzD. Furthermore, these new observations could be inserted to clast geometric system defined in Chapter II., and revealed numerous, interrelation between the degree of deformation, stress - strain curves and presumed reservoir properties of the fault rocks.

Chapter IV. presents an attempt to partly reconstruct the post-metamorphic structural evolution of Szeghalom Dome, focusing on to observe the main fault zone systems of the study area and to define their role in the past or recent petroleum system of the area. This chapter is strongly based on integrated borecore and well-log interpretation with the findings formulated in the previous chapters of the dissertation or earlier works on the area. 
Finally, in Chapter V. the summary and conclusions of the whole thesis will be presented, with the possible direction of the further researches, both on the basement of the PB and the nature of the fault rocks. An aggregated reference list can be found at the end of the dissertation. 
Chapter II.: Statistical characterization of brittle and semi-brittle fault rocks: a clast geometry approach

Manuscript published in the Acta Geodaetica et Geophysica: 49/4, 527-550 p.

Doi number: 10.1007/s40438-014-0067-3

\section{Authors:}

László Molnár

Department of Mineralogy, Geochemistry and Petrology, University of Szeged, Hungary

Tivadar M. Tóth

Department of Mineralogy, Geochemistry and Petrology, University of Szeged, Hungary

Félix Schubert

Department of Mineralogy, Geochemistry and Petrology, University of Szeged, Hungary 


\section{Statistical characterization of brittle and semi-brittle fault rocks: a clast geometry approach}

\section{Abstract}

In the present approach, clast geometric parameters - Particle Size Distribution (PSD), Clast Complexity $\left(D^{R}\right)$, Aspect Ratio (AR), Circularity (Circ), Convexity (Conv) and Clast Orientation (Angle) - were examined in order to separate the diverse fault rock types (fault breccias, cataclasites and fault gouges), which typically own extremely different hydraulic and petrophysical properties. The available borecore samples were studied in a case of a thrust fault zone from the metamorphic basement of the Pannonian Basin, Hungary. Multivariate statistical methods were applied in order to find the geometric parameters that define the tectonites. The calculated discriminant functions emphasized the importance of the PSD, Angle, AR, and Circ parameters, in descending order. We defined proper combinations of geometric parameters which can clearly separate the fault rock groups, both pair-wise and jointly for the three groups. The discriminant functions also pointed out the relatively similar geometric features of fault breccias and cataclasites in contrast to the significantly different characteristics of fault gouges. The multidimensional scaling demonstrated a three-phase evolution of the analysed brittle tectonites, where the initial deformation is coupled with chaotic fabric giving a weakly disaggregated fault breccia texture. The transitional stage can be characterised by cataclastic flow, while in the most deformed fault gouge samples the strong fragmentation, clast-rounding and oriented texture dominate. These results possible provide constraints on the development and overall behaviour of the fault zone.

Keywords: Brittle tectonites, Fault rocks, Petrograhic Image Analysis, Tectonite discrimination, Borecore data 


\section{II.1 Introduction}

\section{II.1.1 Brittle fault zones and their flow properties}

Intensively fractured basement reservoirs have an increasing role in water and hydrocarbon production worldwide (P'an, 1982; Nelson, 2001; Petford and McCaffrey, 2003). In these fields, brittle fault zones play an important part in the hydrodynamics of the whole rock masses (Caine at el., 1996), as the upper crustal (down to 10-15 km depth) deformation structures can govern the local hydrodynamic-systems, by their barrier, conduit or combined behaviour (Antonellini and Aydin, 1995; Caine et al., 1996; Evans et al., 1997; Billi et al., 2003; Storti et al., 2003; Manzocchi et al., 2010). In the past years, a large number of studies have realised the importance of these structures and addressed numerous papers for understanding the role of fault zones in hard-rock reservoirs.

The hydraulic character of a brittle fault zone - besides many other parameters (recent stress-field, cementation, dissolution, depth and water saturation (Wibberley and Shimamoto, 2003; Faulkner et al., 2010 among others)) - primarily depends on the consisting tectonites, which are strongly affected by the interplay of their formation factors, like the protolith type, the degree of deformation, physical constraints of the paleostress field, and many others (Caine et al., 1996; Fossen et al., 2007; Manzocchi et al., 2010). The various types of fault rocks have extremely different flow-properties, thus governing diverse hydraulic regimes, even in the reservoir-scale.

Numerous studies have revealed that brittle displacement zones can be divided into two main structural elements (Caine et al., 1996; Lee and Kim, 2005; Ben-Zion and Sammis, 2003; Hausegger et al.; 2010): first, the weakly disaggregated, densely fractured "damage zone" generally with highly elevated conductivity and permeability relative to the undeformed protolith; second is the strongly deformed and crushed fault core, where the pre-existing rock fabrics are erased by the fault development and replaced by fault rocks. This localised zone is the locus of the most of the 
accommodated displacement, coupled with a dramatic drop in the permeability, compared with the damage zone.

Weakly fragmented and comminuted, coarse-grained fault breccias are often observable in the fault core, adjacent to the damage zone. These have a slightly decreased permeability in comparison with the densely fractured damage zone, but a much higher permeability than the protolith and other parts of the fault core. For this reason, several authors regard these coarse breccia surfaces as the "boundary zone" (Wibberley and Shimamoto, 2003; Billi et al., 2003).

The most important fault rocks in the fault core are usually cataclasite and fault gouge, which - due to the pervasive deformation - have suffered the strongest fragmentation (cataclastic deformation: "comminution", intensive clast rotation, "abrasion" and "chipping") (Sammis et al., 1986, 1987; Blenkinsop, 1991; Storti and Balsamo, 2010), and the planes of the most considerable displacements. Advanced failure can be observed in their well-developed internal microstructure, decreasing amount of clasts against matrix, cement and pore space and the loss of original internal cohesiveness, which also allows the classification between cataclasite and gouge. Generally, increasingly localised slip-planes evolve coupled with a dramatic permeability decrease in the fault core, as a result of a positive feedback between the intensive failure and fault-rock weakening. In total, cataclasite and fault gouge zones can be regarded as local, hydrodynamic barrier bands in reservoir-scale (Caine et al., 1996; Evans et al., 1997; Manzocchi et al., 2010).

The large-scale spatial interpretation of basement faults in the subsurface and their hydrodynamic parameters is problematic, as their appropriate geophysical characterisation is quite uncertain. As these tectonites resulted from the interplay of numerous, previously mentioned factors, it is a difficult challenge to find some, generally applicable geophysical parameters for identification of different segments of fault zones (Bistacchi et al., 2010; Jeppson et al., 2010). Structural extension can be more problematic, as it is a challenge to define the place of the core samples in the idealised fault zone in the lack of outcrop, and even more challenging to determine their extension according to $1 \mathrm{D}$ data. These facts increase the role and value of the core-samples, 
but, on the other hand, raise the necessity of a proper petrographical classification system for brittle fault rocks.

\section{II.1.2 Classification of tectonites and the key problems}

Aside from a few early attempts, the main petrographic classification systems of brittle tectonites are based on specific textural and microstructural properties, described by numerous studies (Sibson, 1977, 1986; Chester et al., 1985; Sammis et al., 1986; Laznicka, 1988; Tanaka, 1992; Woodcock and Mort, 2008). In these works, the following are the most frequent parameters: the ratio of visible clasts to matrix, cement, and pore space ("ratio of porphyroclasts", mainly volume per cent), the grain-size, and the "cohesiveness" of the samples (Table II.1).

\begin{tabular}{|c|c|c|c|c|}
\hline \multicolumn{5}{|c|}{ Brittle fault rock classification } \\
\hline \multicolumn{3}{|c|}{ Criteria } & Tectonite type & Grain size \\
\hline \multirow{3}{*}{ Incohesive } & \multirow{3}{*}{ Ratio of porphyroclasts (VN \%) } & $>30$ & Fault breccia & $2 \mathrm{~mm}<$ \\
\hline & & $<30$ & Cataclasite & $0.01-2 \mathrm{~mm}$ \\
\hline & & $<10$ & Fault gouge & $0.01 \mathrm{~mm}>$ \\
\hline \multirow{6}{*}{ Cohesive } & \multirow{6}{*}{ Ratio of porphyroclasts (VN \%) } & $>90$ & Protobreccia & $5 \mathrm{~mm}<$ \\
\hline & & $90-30$ & Breccia & $2-5 \mathrm{~mm}$ \\
\hline & & $<30$ & Protocataclasite & $0.1-2 \mathrm{~mm}$ \\
\hline & & $<30$ & Cataclasite & $0.001-0.1 \mathrm{~mm}$ \\
\hline & & $<10$ & Ultracataclasite & $0.01 \mathrm{~mm}>$ \\
\hline & & $<10$ & Pseudotachyllite & $0.005 \mathrm{~mm}>$ \\
\hline
\end{tabular}

Table II.1: Classification of fault rock-series, adapted from Sibson (1977, 1986), Laznicka (1988), Tanaka (1992) and Woodcock and Mort (2008).

The influential works of Sibson $(1977,1986)$ stated that, in the classification of the fault rocks, clast ratio and size, cohesiveness and the development of foliations are the most important properties. Generally, the increasing deformation - due to its mechanism (fragmentation, abrasion, and comminution) results in a decrease in clast size and also in the ratio of clasts per area to matrix, 
pore-space, and cement. Woodcock and Mort (2008), according to the sedimentological usage, determined $2 \mathrm{~mm}$ as the grain size limit between coarse- and fine-grained fault rocks, because if $30 \%$ of clasts are larger than $2 \mathrm{~mm}$ then the fault rock can be categorised as fault breccia, while the cataclasites are below that limit. A fault gouge is identified where only a few isolated clasts occur in the matrix (the optically visible amount of fragments is under 10\%) (Passchier and Trouw, 2005).

However, the $2 \mathrm{~mm}$ clast size limit does not necessarily mean a change in the deformation mechanism, strengthening the statement that grain size is only a descriptive category, and there may be many more informative genetic factors, such as particle-size distribution (PSD) (Sammis et al., 1986; Blenkinsop, 1991, Jébrak, 1997); in contrast, grain size is only a simple tool for field interpretation of the fault rocks.

In numerous cases, the fault rocks may have retained some primary cohesion (Sibson, 1977), for example as a result of the diffusive mass transfer and sub-critical fracture growth or obtained through the post-faulting processes, due to the precipitation of cement-minerals from crustal fluids. The primarily incohesive fault rocks - defined by Brodie et al. (2007) as capable of being broken into component granules with finger - are mainly the result of shallow-depth deformation. However this fabric is quite often overprinted by the above mentioned precipitation, resulting in secondarily cemented structure (Woodcock and Mort, 2008) and causing some difficulty in the definition of primary cohesion/incohesion. The proposed fault-rock scheme of Woodcock and Mort (2008) omits the cohesion as an important criterion, qualifying all coarse-grained fault rock as fault breccia. The only exception that can be regarded as incohesive is the fault gouge, although it is possible that incohesive structure is related to the weathering of the fine-grained cohesive fault rocks (Woodcock and Mort, 2008).

Fault rocks, which tend to form by brittle shearing, have long been regarded as having only random fabric, without any structural indicators of the direction of the shear (Engelder, 1974; Sibson, 1977; Tanaka, 1992). More recent papers (Chester et al., 1985; Cladouhos, 1999; Wibberley and Shimamoto, 2003) have proven that there are also observable shear indicators in brittle 
tectonites; however, in the weaker disaggregated breccias, a lack of any orientation is rather frequent, too.

Generally, the formation of cataclasites and fault gouges with foliations and asymmetric structures represents pervasive deformation at both the mesoscopic and microscopic scales (Chester et al., 1985), whose results resemble ductile shear and produce stretching lineations analogous to mylonites (Lin, 1999), while the deformation is brittle. Numerous microstructural manners are able to determine the sense of shear; the most frequent indicators are microfaults, shear planes, (grain) shape-preferred orientation, inherited micas, and deformational bands (Passchier and Trouw, 2005). Both granular and clay gouges usually show well-developed foliation in the surviving grains and the surrounding clay-rich matrix (Cladouhos, 1999). However, care should be taken in the interpretation of the deformation indicators (especially in linear structures) (Tanaka, 1992), as their fabric often shows only the last stage of the displacement history. The mentioned pseudo-ductile shear in rocks lacking cementation can dramatically lower the internal cohesiveness of strongly comminuted fault rocks.

Although there are numerous textural and microstructural parameters for the classification of brittle tectonites, in this study we attempt to analyse their geometric features and then compare the results with the earlier data in the literature.

\section{II.1.3 Main aim of the paper}

Earlier studies (Sammis et al., 1986, 1987; Blenkinsop, 1991; Jébrak, 1997; Bérubé and Jébrak, 1999; Clark and James, 2003; Billi et al., 2003; Storti et al., 2003; Billi and Storti, 2004; Billi, 2007; Mort and Woodcock, 2008; Storti and Balsamo, 2010) demonstrated a connection between some geometric parameters of fault rocks and their formation conditions, as different degrees and types of fragmentation processes induce definite changes in the clast geometry.

In this case, our measurements are based on geometric parameters of the clasts resulting 
from deformation, as numerous studies have examined their development in both natural and experimental conditions (Jébrak, 1997; Keulen et al., 2007, Stünitz et al., 2010 among others). A wide set of these geometric parameters were analysed by the Petrographic Image Analysis (PIA) approach, where digitalised two-dimensional images of the samples (core samples at meso-scale and thin sections at micro-scale) are processed by a proper image analysis program.

This paper aims to define the most characteristic clast geometric parameters of different fault rock types, which were previously qualitatively classified by their microstructural features. As these tectonites have rather distinct hydraulic and petrophysical properties (porosity, permeability), the understanding of the main deformational mechanisms may promote a proper hydrogeological interpretation of the fault zones. The more accurate 1D extension of lithological information via the core to log the calibration of wells can be a further benefit of this method, especially in the case of re-evaluation of old wells (e.g. without borehole imaging).

Our classification attempt will be introduced through a case study on a basement fault zone from the Pannonian Basin; however the main focus of the paper is to reveal the geometric aspects of the distinct deformation mechanisms rather than to obtain some new results on the local geology.

\section{II.2 Applied methods}

\section{II.2.1 Description of Petrographic Image Analysis}

Beyond the traditional microstructural analysis of the samples, which included the definition of the dominant fault rock types and lithologic composition of the clasts, digital image techniques were applied to determine the geometric characteristics of the particles. The Petrographic Image Analysis of meso- and micro-scale samples was used on their two dimensional pictures. Image processing of the bore-core samples was performed on core-scanner pictures (Fig. II.1): samples 
with intact cylinder-shape could be scanned, resulting in photographs of their outstretched mantle. The photographs were taken by the ImaGeo core scanner in the Hungarian Geological and Geophysical Institute (Maros and Pásztor, 2001), with a high resolution digital camera, using the highest possible quality $(0.075 \mathrm{~mm}$ pixel size $)$. The micro-scale analysis was achieved on microphotographs from selected, structurally representative parts of thin sections, with constant magnification $(\times 10)$. In this case, clasts could not be segmented by the usage of a specific threshold tool as the matrix or cement was too heterogeneous, so the selection of edges was accomplished manually, one by one, using Corel Draw Graphic Suite X3. The clast geometric measurements were completed using the selected parameters in the open source ImageJ 1.48.

\section{II.2.2 Measured parameters}

\section{II.2.2.1 Particle Size Distribution (PSD)}

Many solutions have been proposed for describing brittle tectonite particle size distribution (PSD). As a consequence, some earlier studies (Sammis et al., 1986, 1987; Turcotte, 1986) demonstrated the fractal character of the cumulative $P S D$, with the following equation: $N(s) \sim s^{-D s}$, where $N(s)$ is the number of particles smaller than a size $s$ (square root of the area (Blenkinsop, 1991, Clark and James, 2003)), while $D^{S}$ can be determined as the slope of the best fit line on a ln $N(s)$ against $\ln s$ graph. Different $D^{S}$ values are expected for varying degrees of fragmentation process.

\section{II.2.2.2 Clast complexity $\left(D^{R}\right)$}

Several techniques can be used for the determination of clast complexity (structured walk, box counting, dilation, Euclidean distance mapping, etc.), from which, according to Bérubé and Jébrak (1999), the "Fractal Dilation" is the most precious method.

The "Fractal Dilation" macro of Image SXM uses a 1 pixel-wide outline of the clasts, which 
is later thickened by the macro, creating 2, 4, 8 and 16 pixel-width ribbons (Kaye, 1989; Clark and James, 2003). The area of these ribbons is plotted against its thickness on log-log plot, resulting in a line with an $S$ slope, which is the indicator of clast-complexity fractal dimension $\left(D^{R}\right)$ using the 2$S=D^{R}$ equation (Kaye 1989).

\section{II.2.2.3 Aspect Ratio (AR)}

The Aspect Ratio (AR) is the proportion of the long and short axes of the ellipse that fits best to the clast's outline. The ellipse has the same area, long-axis orientation and centre as the original grain, defined by ImageJ. AR is the degree of elongation of the clasts affected by the tectonic deformation (Barnett, 2004; Heilbronner and Keulen, 2006).

\section{II.2.2.4 Circularity (Circ)}

The value of circularity can be expressed by the equation of $4 \pi\left(A P / p^{2}\right)$, where $A P$ is the area of the clast, and $p$ is its perimeter (Barnett, 2004; Mort and Woodcock, 2008). This measures how close the particle's shape is to a perfect circle. According to the above formula, the value of the Circ varies between 0 and 1 , where 0 is an immensely elongated ellipse, while 1 is a perfect circle.

\section{II.2.2.5 Orientation Angle (Angle)}

Shape preferred orientation (SPO), or grain shape preferred orientation (GSPO) (Passchier and Trouw, 2005), of the brittle deformation-surviving grains (especially in the fault gouge) can show a preferred orientation (Tanaka, 1992; Keulen et al., 2007). The numerical value of orientation for a single clast is the angle between the long-axis of the clast's best-fit ellipse and the lateral (the "X") axis of the image. In this case, our core samples were not oriented, so the possibly evolved orientation is only observable in the lowering of the dispersion from the average Angle values of the clasts, which is numerically manifested in the changes of relative standard deviation values. 


\section{II.2.2.6 Convexity (Conv)}

Convexity measures the surface roughness of a particle, calculated by dividing the convex hull perimeter by the actual particle perimeter. Very smooth shapes have a Conv value close to 1 , while very spiky and irregular objects have a Conv value closer to 0 .

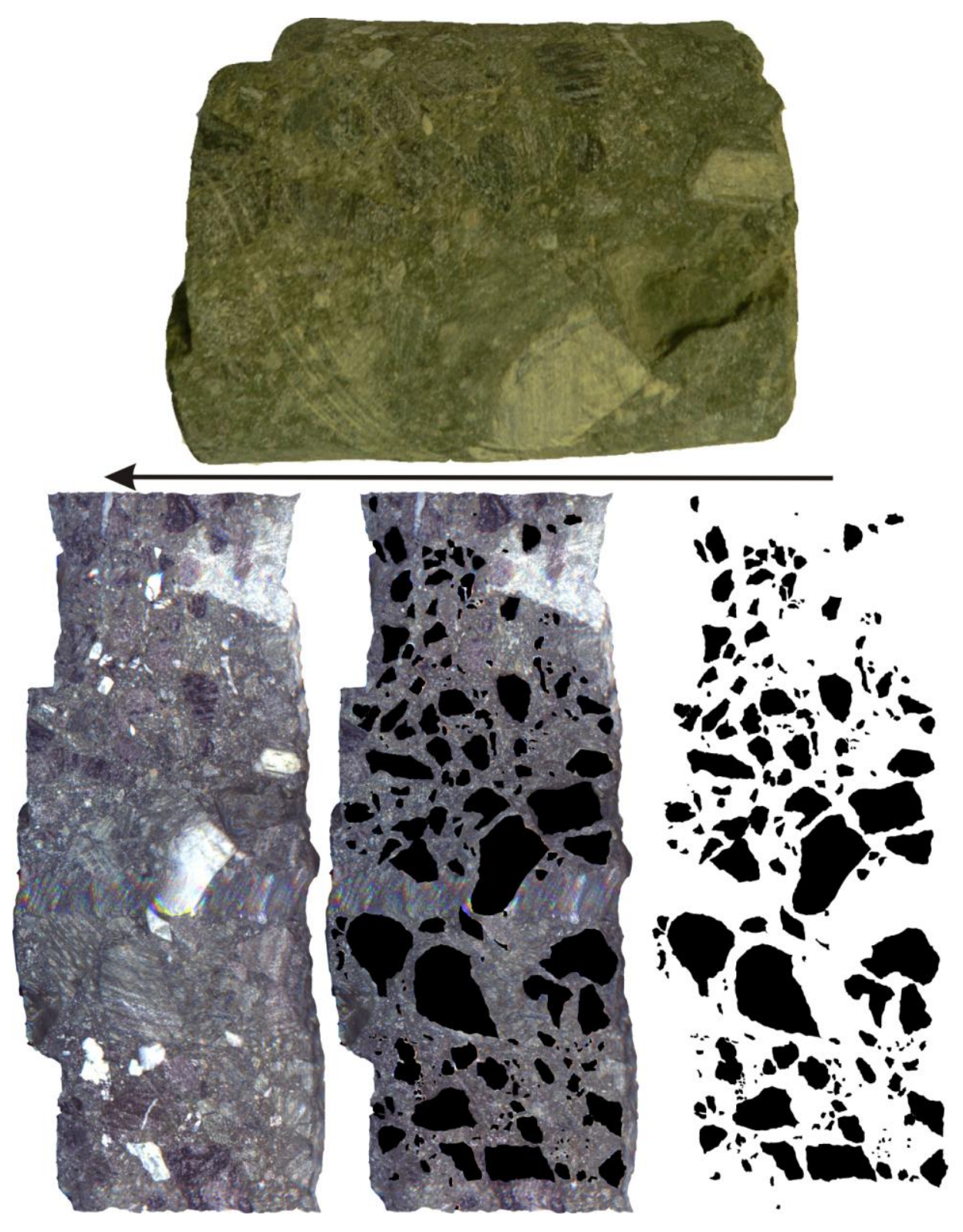

Figure II.1: a: Core-sample from metamorphic basement of the Pannonian Basin. b: Scanned core photo.

c: Clasts selected for the measurements, drawn one-by-one in Adobe Photoshop. d: Separation of clasts from the matrix for the measurements in ImageJ. Arrows indicate the long axis orientation of the core. 


\section{II.2.3 Multivariate statistical methods}

Multivariate statistical methods (discriminant function analysis and multidimensionalscaling) were applied in order to answer the following questions: 1) how reliably can the fault rock types be distinguished based on their geometric parameters, 2) which parameters are responsible for characterisation of each group and 3) how do the different stages of deformation manifest in the measured PIA parameters. Discriminant function analyses were performed to define which parameters participate in the distinction of differ tectonite types, and to what level, both for pairwise and for all three groups. Discriminant functions were calculated with the forward stepwise method using Wilks' lambda. The probability of F-to-enter was lower than 0.050, the probability of F-toremove was above 0.100 and the prior classification probabilities were equal for the lithologic groups. Discriminant functions were cross-validated to test the efficiency of the prediction model. The aim of multidimensional-scaling was to set the place of the samples in the theoretical sixdimensional space of the measured parameters. This method can illustrate the evolution of the particles from the aspect of geometric parameters and define which parameters can mark the different stages of deformation. The scree test of the multidimensional-scaling was also computed: the plot of the stress values against the different number of dimensions. The procedure is similar to the method of Cattell (1966), which was proposed originally for the factor analysis. IBM SPSS 20.0 Statistics was applied for the statistical evaluation of the results.

\section{II.3 Case-study: Crystalline basement of the Pannonian Basin}

The above techniques and their application are introduced in a case study from a basement fault zone in the Pannonian Basin. The Variscan metamorphic basement of the Pannonian Basin is intensely fractured as a result of a complex post-metamorphic structural evolution and consists of 
numerous fractured hydrocarbon reservoirs, where the proper understanding of the fault zones is essential. One of the most important of these basement reservoirs is the crystalline Szeghalom Dome (Nelson, 2001), which is mainly composed of gneisses of various metamorphic histories.

Szeghalom Dome lies in the northern margin of the Békés Basin, the largest sub-basin in the southern part of the Pannonian Basin, which is surrounded by elevated basement highs, such as the studied area (Fig. II.2). The multi-stage tectonic evolution of the area resulted in a dense fracture network of the host rock body. Following the Variscan metamorphism, the most essential tectonic event was the Cretaceous compression of the Codru nappe system, which was proved by numerous earlier papers in the whole basement of the Pannonian Basin (Tari et al., 1999, Posgay et al., 1995). Moreover, the seismic interpretation on the Szeghalom Dome also indicated the presence of wide thrust zones throughout the crystalline high (M. Tóth et al., 2009). As a result, metamorphic blocks with rather distinct evolutions (M. Tóth, 2008) were juxtaposed along these thrust surfaces, with amphibole gneiss on the hanging wall and sillimanite gneiss in the footwall. 


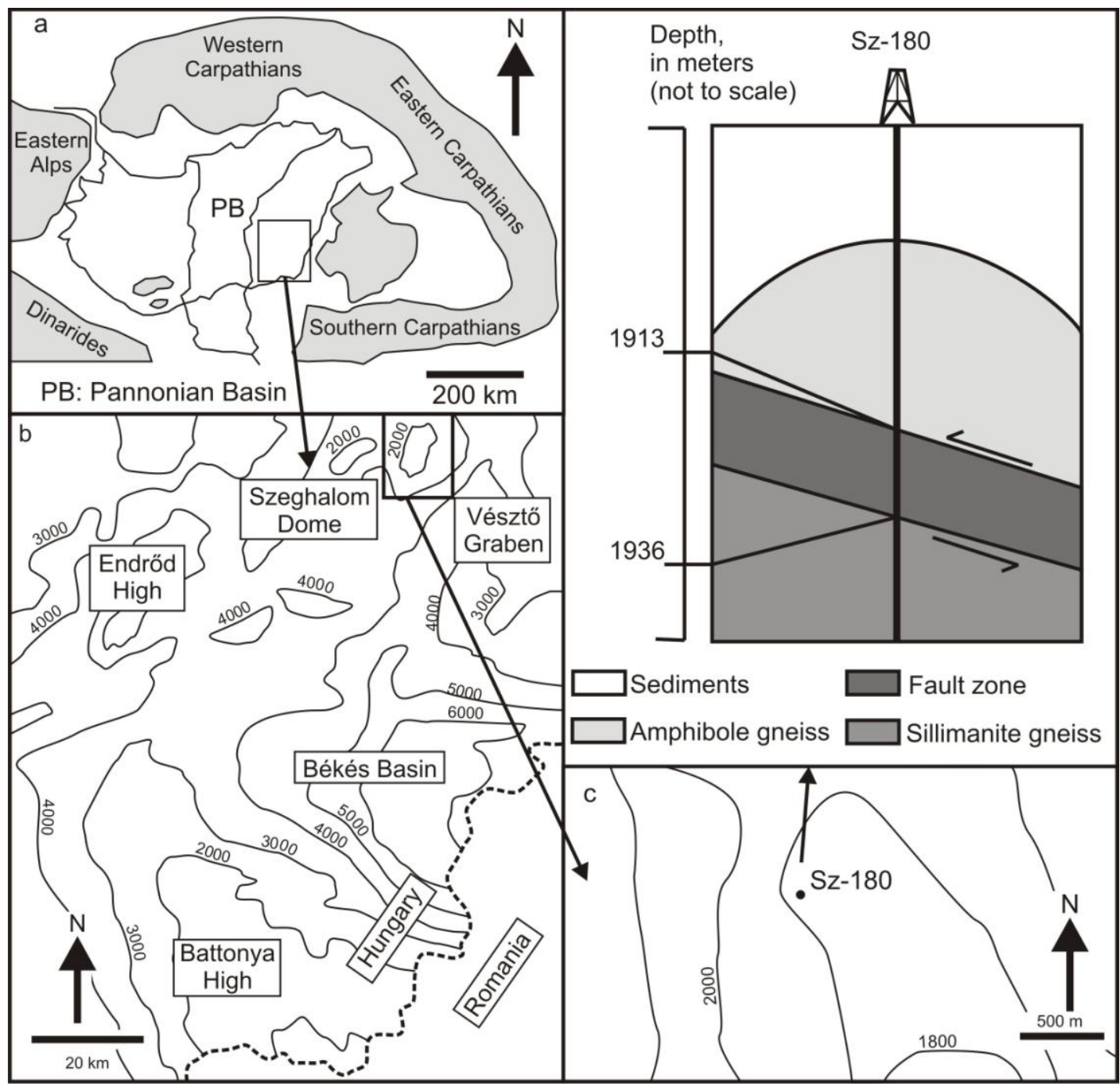

Figure II.2: Location of the Szeghalom Dome in the Pannonian Basin and their geological environment.

The contoured map indicates the depth to the basement in meters. The figure (d) marks the depth interval of the investigated samples in a schematic north to south cross-section of the area.

One of these major fault zones was penetrated by a well (A-180), situated north of the central and most elevated part of Szeghalom Dome, with close to $100 \%$ core recovery, making a detailed petrological investigation possible: 7 borecore (meso-scale sample) and 24 thin section (micro-scale sample) were involved in the evaluation. The examined section is approximately $20 \mathrm{~m}$ wide and quite heterogeneous petrographically. As the sampled fault zone - according to the palaeo-fluid investigations (Schubert et al., 2007) and the recent hydrocarbon production data - is the main migrational pathway inside the studied crystalline basement high, the classification of fault rocks 
with significantly different hydraulic properties is crucial.

\section{II.4 Results}

\section{II.4.1 Petrography}

Internal structure of the shear zone reflects strong diversity from petrographic aspects, consisting of different tectonites (breccia, cataclasite, foliated cataclasite, fault gouge). Most of the analysed meso- and micro-samples were composed of coarse fault breccia, with weakly disaggregated structures, and often with clast sizes over one mm-scale (Fig. II.3/a-b). Particles are slightly or not rotated, moreover a local mosaic, "jigsaw" texture can be observed, where the clasts are relatively easy to fit together along their sharp, angular dilation edges. The lack of any orientation and the random, chaotic structures are general in coarse fault breccia samples. These samples are clast-dominant, where the clast ratio is mainly over $30 \%$. Particles are dominantly composed of rock-fragments, derived from the wallrock, with recognisable gneiss protolith. Mineral fragments are subdominant in the coarse fault breccia samples.

On a few thin-sections, the manners of cataclastic deformation are observable (Fig. II.3/c-d). These specimens are usually embedded in breccia regions. Cataclasis resulted in decreasing clast size and increasing matrix/cement ratio. The possible appearance of local orientation is defined by the long-axis of the elongated clast, often coupled with deformed phyllosilicate flakes. These rock types reflect anastomising texture with local pseudo-ductile fabric as well. The protolith of the strongly deformed particles is locally hard to observe, they are often composed of only a single mineral phase (mainly quartz or feldspar). 

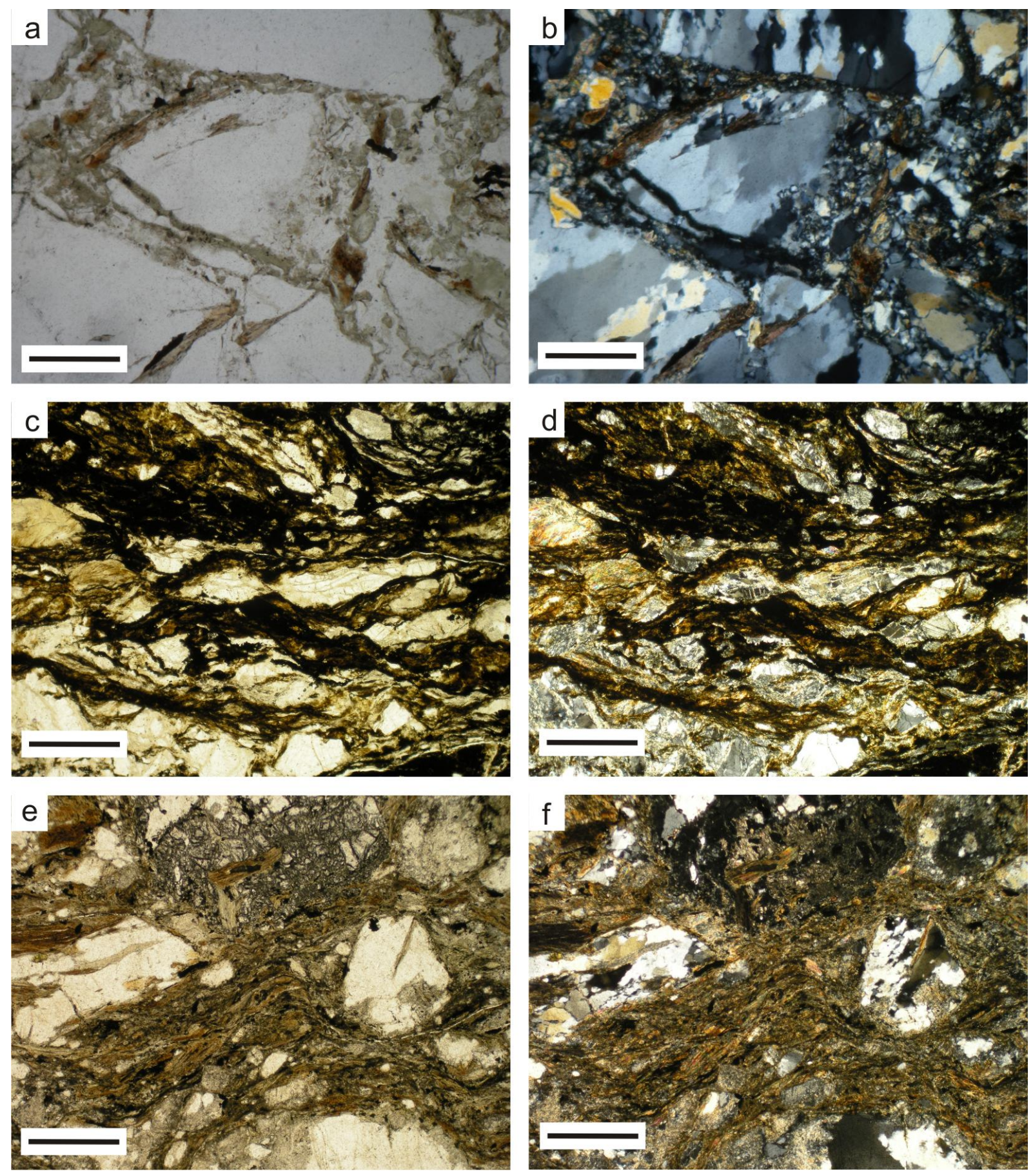

Figure II.3: $a$, $b$ : Coarse fault breccia, containing rock (gneiss) fragments ( $a$ : in plane polarized light, $b$ : in cross-polarized light). $c$, d: Oriented, elongated ribbons of clasts in foliated cataclastic fabric (c: in plane polarized light,d: in cross-polarized light). e,f: Layers of comminuted gouge contains mainly crushed mono-crystals (e: in plane polarized light, $f:$ in cross-polarized light). The scale bars are 500 micrometer. 
Incohesive, granular gouge structures are observable only in thin deformational bands (Fig. II.3/e-f). These stages are the most crushed parts of the fault zone, which are mainly built up by extremely deformed mono-crystalline clasts. These isolated clasts are surrounded by the totally crushed parts of the protolith, also showing an anastomising structure, composing a "flow-banded" fabric. Most of the particles are single mineral grains; only a few survivor rock-fragments are observable. Gouge-bearing bands are always visible embedded in the foliated cataclasite bands. These few cm wide zones can mark "slip-zones" of the fault zones; these denote the places of the largest displacements.

According to the studied samples, in the fault zone in question, three main rock types can be distinguished based on their microstructural features:

- Coarse fault breccia (Group I)

- Cataclasite bands (Group II)

- Strongly deformed, thin gouge layers (Group III)

\section{II.4.2 Results of PIA}

The rather complex internal structure of the examined fault zone makes its geometric parameters suitable for comparison by PIA. The measured values for different tectonite types are summarised in Fig. II.4, where numbers of the samples indicate their order in the increasing fragmentation estimated from the microstructural observations.

The $P S D$ fractal dimensions reflect significant, constant increases, both in micro- and mesoscale samples, as the texture becomes more disaggregated; this is in parallel with the petrographically-defined increasing deformation, $D^{S}$ dimensions also emerge (Fig. II.4/a). The intensively comminuted gouge-bearing zones have the highest $D^{S}$ results $(>1.7)$ and only the values of Group III samples exceed the theoretical value of $\sim 1.6$ for comminution and cataclasis (Biegel et al., 1989). 

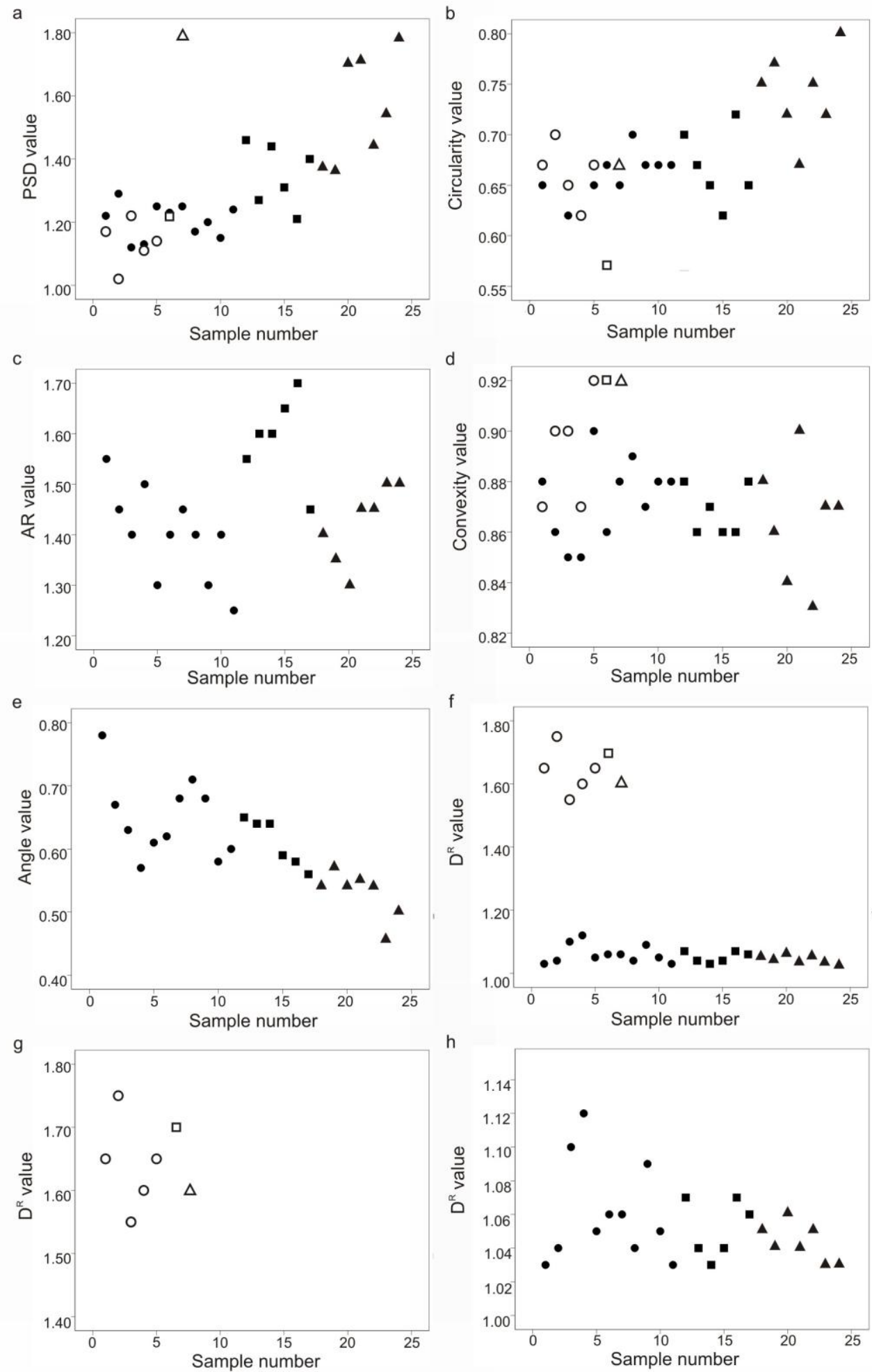

-/O : Fault Breccia (micro/meso scale) ㅁ: Cataclasite (micro/meso scale) $\Delta / \Delta$ : Fault Gouge (micro/meso scale)

Figure II.4: Results of all geometric parameters. Samples are arranged in order of increasing disintegration. The degree of disintegration was estimated from the microstructural observations. The results of figure $(f)$ are separated into figure $(g)$ and $(h)$, due to their strongly different values. 
a

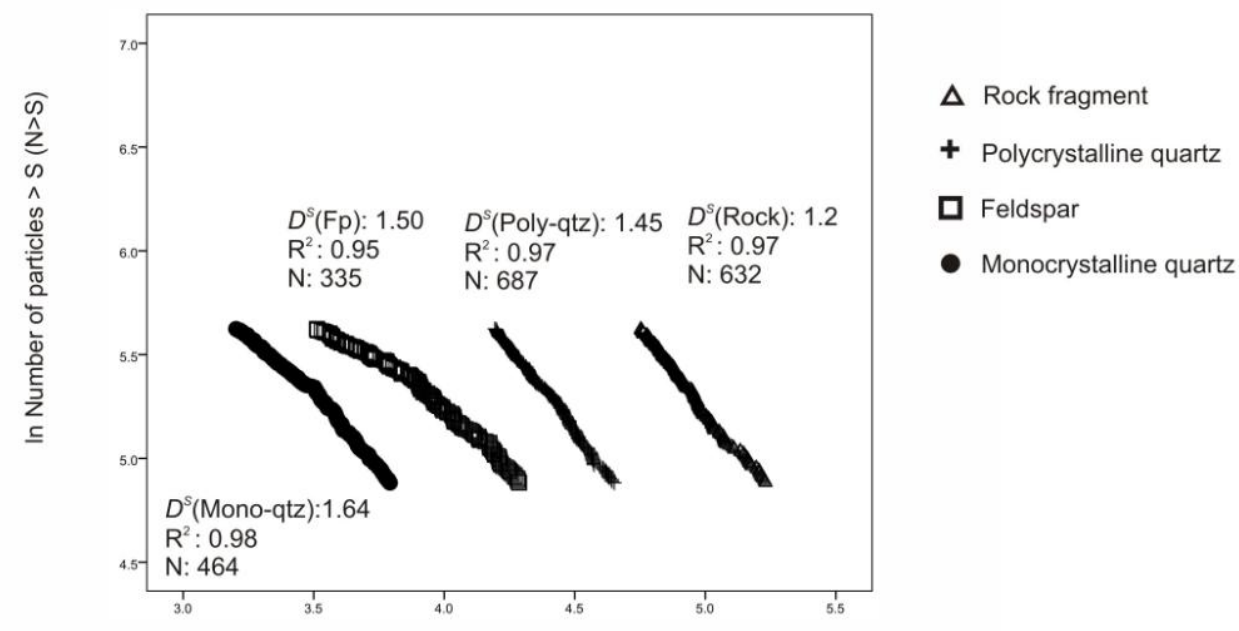

b
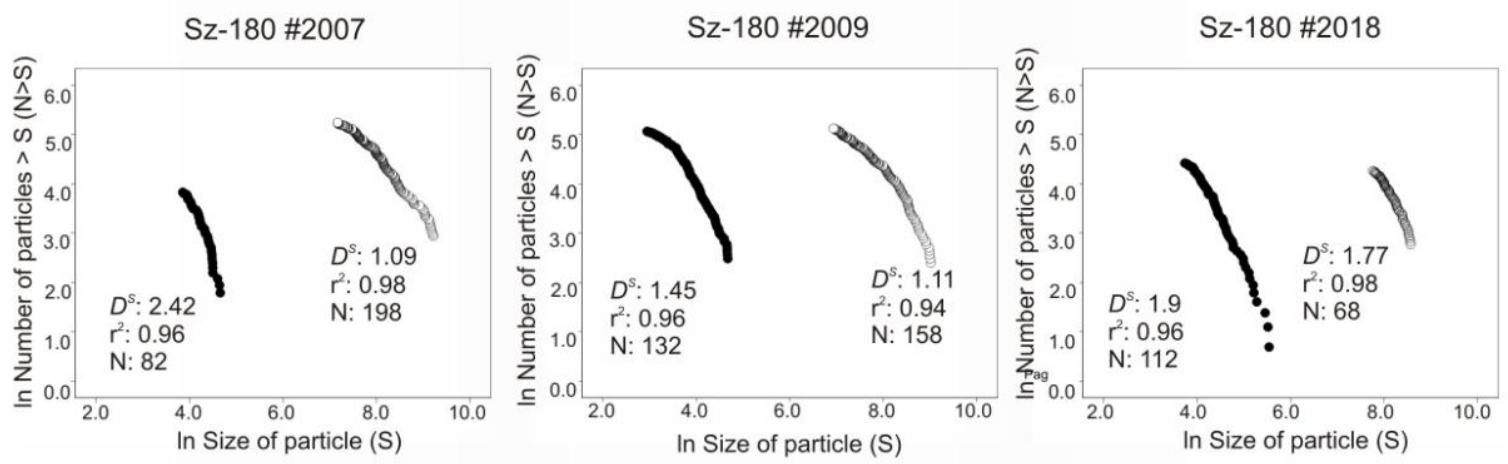

- Micro scale omeso scale

Figure II.5: a: The PSD values of different lithologies show rock fragments $\rightarrow$ polycrystalline quartz $\rightarrow$ feldspar $\rightarrow$ monocrystalline quartz order of fragmentation. Note: extreme grain sizes close to the lower and upper limit are neglected, as these clasts misfit at the scale of observation. b.: Comparison of PSD values of meso- and micro-scale samples from similar depth-interval. The micro-scale samples show constantly stronger fragmentation. Extreme grain sizes were also neglected in the measurement.

From the aspect of clast material, the four main clast-lithology types (rock-fragments, feldspar, poly- and monocrystalline quartz, respectively) follow different $P S D$ values, in increasing order of rock-fragments, polycrystalline quartz, feldspar and finally monocrystalline quartz (Fig II.5/a). In the comparison of the meso- and micro-scale PSD data, it is clearly visible that the mesoscale samples have constantly lower particle size distribution dimensions than the micro-scale 
values from the same depth interval below the surface (Fig. II.5/b). The transitional gap from the upper size limit of micro-scale samples to the lower size limit of the meso-scale samples is always observed in the grain size range between $0.4 \mathrm{~mm}^{2}$ and $0.7 \mathrm{~mm}^{2}$ (Fig. II.5/b).

Circ values show a moderate increase in the Group III samples: all of these samples fall above 0.65 (Fig. II.4/b). The two less fragmented classes have smaller values without any other trends; results in both classes are in a narrow interval (in 0.6-0.7 Circ values), although the Group II samples reflect a slightly increased dispersion in their values.

There is no significant tendency in the values of $A R$ parallel with the observed deformation; only a moderate increase is visible in the results of Group II samples in comparison with other classes: all but one Group II sample have $A R$ values over 1.5 (Fig. II.4/c). In contrast, the Group I and III tectonites usually have $A R$ values lower than 1.5 (Fig. II.4/c). Meso-scale measurements of $A R$ cannot be applied, because of the geometric distortion derived from the scanned cylinder shape samples mantle, resulting in false major/minor axis ratios.

No visible trend can be observed between the results of Conv and the different tectonites (Fig. II.4/d). Mode of convexity values are between 0.8 and 0.9 for every sample, both at microand meso-scales. The only remarkable characteristic is a relatively limited concentration of Group II values around $0.86-0.88$.

In contrast, there is a clear correlation between the degree of deformation and the clast orientation. Relative standard deviation of Group III samples yields lower Angle values ( around 0.5) than the other two classes, suggesting a more orientated texture with lower fluctuation in the direction of the clast's major axis (Fig. II.4/e). The SPO degree of core samples was not measured because of the misleading results derived from their cylinder-shape.

From the aspect of clast-complexity values (Fig. II.4/f), there is a strong difference between the core-sample and the thin section results. The first class has values that are constantly higher than 1.5 (Fig. II.4/g), while the latter group gives values that are always below $1.15 D^{R}$ dimension (Fig. II.4/h). A moderate reduction is visible in the $D^{R}$ values parallel with the increasing observed 
deformation, especially in the Group III class.

\section{II.5 Discussion}

\section{II.5.1 Discrimination of tectonites based on geometric parameters}

Based on the results of the microstructural and PIA analysis of the samples multivariate statistical methods (discriminant function analysis and multidimensional-scaling) were applied. Only the micro-scale samples were involved into the evaluation, as this type of sample provided results from each of measured geometric parameter with a sufficient amount of particle (at least 50 per sample), following the instructions of Jébrak (1997) or Clark and James (2003) on the clast geometric analysis. The histograms of the frequency distributions for the variables revealed that the parameter values are normally distributed despite of their minor deviations (Fig. II.6). The correlation and covariance matrices in the Figure II.7 reflect relatively homogeneous dataset, according to the results displayed in Table II.2, especially in the diagonal plots, where correlations of the parameters were plotted against the covariances for each geometric feature.

\section{Pooled Within-Groups Matrices}

\begin{tabular}{|cl|c|c|c|c|c|c|}
\hline & & PSD & DR & \multicolumn{1}{c|}{ AR } & \multicolumn{1}{c|}{ Circ } & \multicolumn{1}{c|}{ Conv } & \multicolumn{1}{c|}{ Angle } \\
\hline Covariance & PSD & .01248 & -.00064 & -.00091 & -.00028 & .00059 & .00025 \\
& DR & -.00064 & .00053 & -.00009 & -.00017 & -.00018 & -.00034 \\
& AR & -.00091 & -.00009 & .00721 & .00000 & -.00023 & .00061 \\
& Circ & -.00028 & -.00017 & .00000 & .00115 & -.00002 & .00025 \\
& Conv & .00059 & -.00018 & -.00023 & -.00002 & .00031 & .00010 \\
& Angle & .00025 & -.00034 & .00061 & .00025 & .00010 & .00260 \\
\hline Correlation & PSD & 1.00000 & -.24772 & -.09617 & -.07490 & .30184 & .04397 \\
& DR & -.24772 & 1.00000 & -.04498 & -.21914 & -.43574 & -.29021 \\
& AR & -.09617 & -.04498 & 1.00000 & -.00138 & -.15099 & .13979 \\
& Circ & -.07490 & -.21914 & -.00138 & 1.00000 & -.03549 & .14632 \\
& Conv & .30184 & -.43574 & -.15099 & -.03549 & 1.00000 & .11683 \\
& Angle & .04397 & -.29021 & .13979 & .14632 & .11683 & 1.00000 \\
\hline
\end{tabular}


Figure II.6: Histograms of the analysed geometric parameters. $\rightarrow$
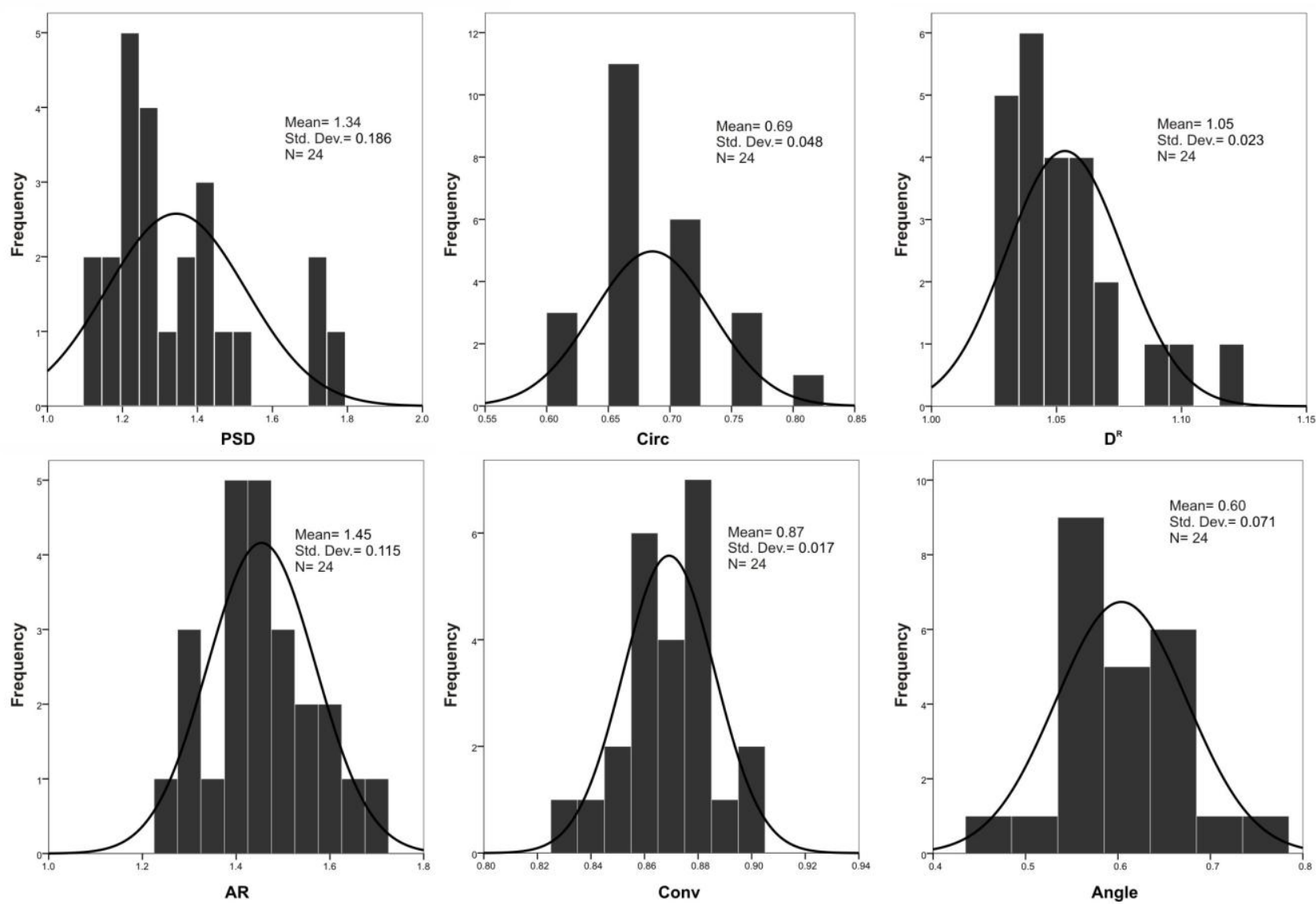

In the discriminant function analysis, first - accepting the petrographic classification - the tectonite types were compared pairwise to each other in the 6-dimensional space of the measured geometric factors to detach the distinct groups based on scores of the functions. The computation of the pairwise discriminant functions was necessary in order to define the main differencies between the microstructurally often strongly similar lithologic groups (fault breccias vs. cataclasites or cataclasites vs. fault gouges) and to reveal the possible similarities of the ungrouped sampes to the grouped samples via predictions. The groups (1: breccia, 2: cataclasite, 3: gouge) were separated by the following discriminant functions:

$$
\begin{aligned}
& \mathrm{D}(1,2)=1.168 * A R+0.996 * P S D-0.858 * \text { Angle } \\
& \mathrm{D}(2,3)=0.905 * A R-0.705 * \text { Circ }+0.642 * \text { Angle }
\end{aligned}
$$




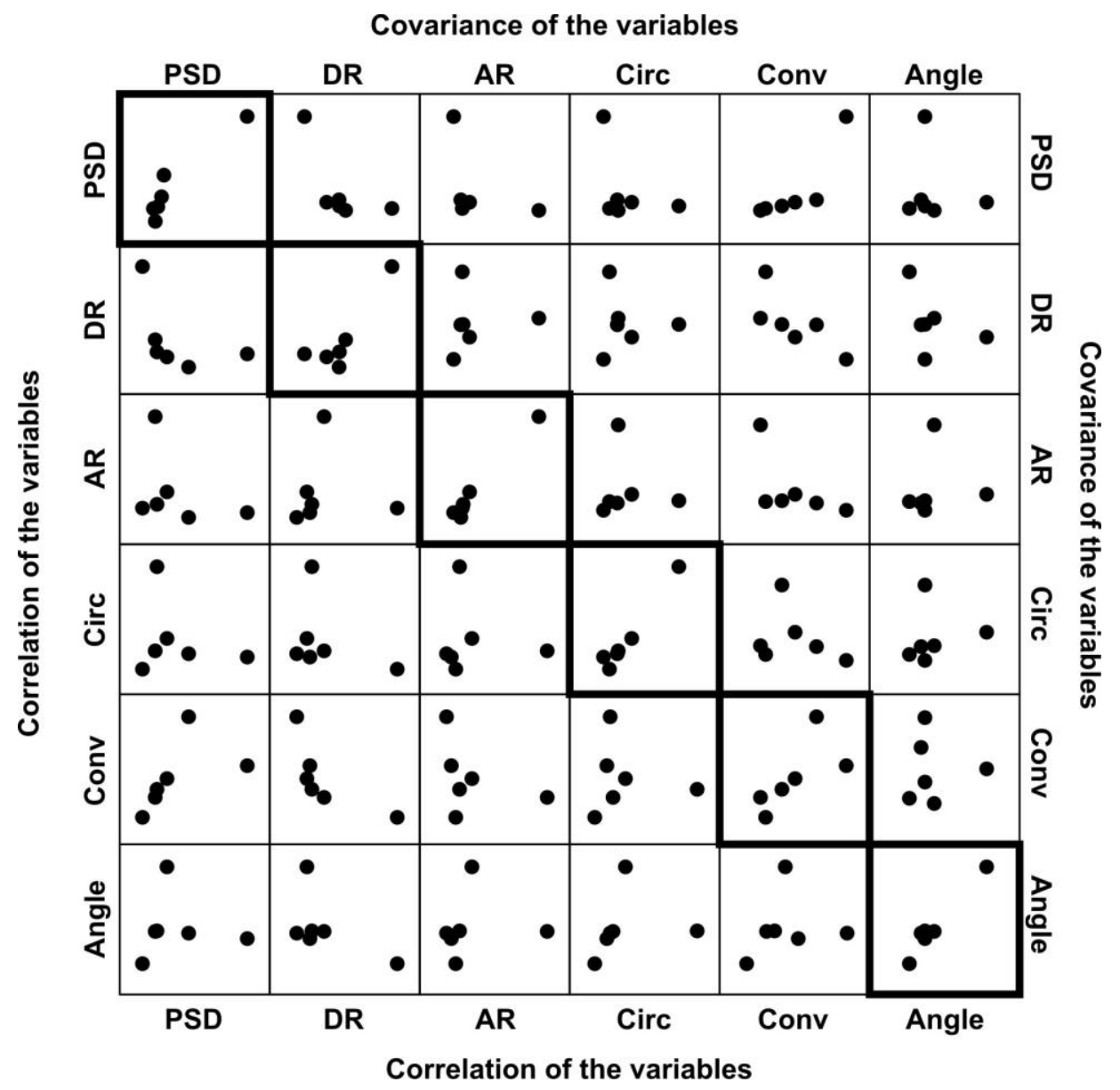

Figure II.7: Scatterplot matrix of the variable's data according to Table II.2. In the lower part of the matrix the correlations of a variable with the other parameters are plotted against the similar data of other parameters. In the upper part, these are displayed in the case of the covariation. In the diagonal plots, the correlations and the covariances were plotted for each parameter.

The significance tests of the discriminant functions are displayed in the Table II.3/a,b: all of the pairwise functions are significant and have a quite good correlation (D1,2: 0.929 D2,3: 0.891, D1,3: 0.924). To test their efficiency, the classification functions were cross-validated and these resulted in a relatively high accuracy (D1,2: 92.3 D2,3: 094.1, D1,3: 100\% of the samples were clasified correctly). In the pairs of groups, the following prediction can be made for the actually ungrouped samples (Fig. II.8/a): 
$\mathrm{D}(1,2)$ : gouge is mainly grouped as cataclasite

$\mathrm{D}(2,3)$ : breccia is mainly grouped as cataclasite

$\mathrm{D}(1,3)$ : cataclasite is mainly grouped as breccia

\begin{tabular}{|c|c|c|c|c|c|}
\hline \multirow{7}{*}{ a } & \multicolumn{5}{|c|}{ Eigenvalues } \\
\hline & Function & Eigenvalue & $\%$ of Variance & Cumulative $\%$ & $\begin{array}{l}\text { Canonical } \\
\text { Correlation }\end{array}$ \\
\hline & D 1,2 & $6.272^{\mathrm{a}}$ & 100.0 & 100.0 & .929 \\
\hline & Function & Eigenvalue & $\%$ of Variance & Cumulative \% & $\begin{array}{l}\text { Canonical } \\
\text { Correlation }\end{array}$ \\
\hline & D 1,3 & $5.840^{a}$ & 100.0 & 100.0 & .924 \\
\hline & Function & Eigenvalue & $\%$ of Variance & Cumulative \% & $\begin{array}{l}\text { Canonical } \\
\text { Correlation }\end{array}$ \\
\hline & D 2,3 & $3.855^{a}$ & 100.0 & 100.0 & .891 \\
\hline
\end{tabular}

a. First 1 canonical discriminant functions were used in the analysis.

b

Wilks' Lambda

\begin{tabular}{|l|r|r|r|c|}
\hline Test of Function(s) & Wilks' Lambda & Chi-square & df & Sig. \\
\hline D 1,2 & \multicolumn{2}{|c|}{.138} & 26.785 & \multicolumn{2}{|c|}{3} & .000 \\
\hline & Wilks' Lambda & Chi-square & df & Sig. \\
\hline Test of Function(s) & \multicolumn{2}{|c|}{.146} & 27.881 & \multicolumn{2}{|c|}{3} & .000 \\
\hline D 1,3 & Wilks' Lambda & Chi-square & df & Sig. \\
\hline & .206 & 15.801 & 2 & .000 \\
\hline
\end{tabular}

D1-2 functions

C

Eigenvalues

\begin{tabular}{|l|r|r|r|r|}
\hline Function & Eigenvalue & \% of Variance & Cumulative \% & $\begin{array}{l}\text { Canonical } \\
\text { Correlation }\end{array}$ \\
\hline 1 & $5.312^{\mathrm{a}}$ & 82.7 & 82.7 & .917 \\
2 & $1.110^{\mathrm{a}}$ & 17.3 & 100.0 & .725 \\
\hline
\end{tabular}

a. First 2 canonical discriminant functions were used in the analysis.

d Wilks' Lambda
\begin{tabular}{|l|r|r|r|r|}
\hline & & & & \\
Test of Function(s) & Wilks' Lambda & Chi-square & \multicolumn{1}{c|}{ df } & \multicolumn{1}{c|}{ Sig. } \\
\hline 1 through 2 & .075 & 50.490 & 8 & .000 \\
2 & .474 & 14.563 & 3 & .002 \\
\hline
\end{tabular}

Table II.3: Details of significance test for the discriminant functions with their roots (eigenvalues) and Wilks' lambdas for the pairwise functions (a) and D1-2 (b). In D1-2 both of the functions add significantly to the classification. 
The significance tests of the discriminant functions are displayed in the Table II.3/a,b: all of the pairwise functions are significant and have a quite good correlation (D1,2: 0.929 D2,3: 0.891, D1,3: 0.924). To test their efficiency, the classification functions were cross-validated and these resulted in a relatively high accuracy (D1,2: 92.3 D2,3: 094.1, D1,3: 100\% of the samples were clasified correctly). In the pairs of groups, the following prediction can be made for the actually ungrouped samples (Fig. II.8/a):

$\mathrm{D}(1,2)$ : gouge is mainly grouped as cataclasite

$\mathrm{D}(2,3)$ : breccia is mainly grouped as cataclasite

$\mathrm{D}(1,3)$ : cataclasite is mainly grouped as breccia
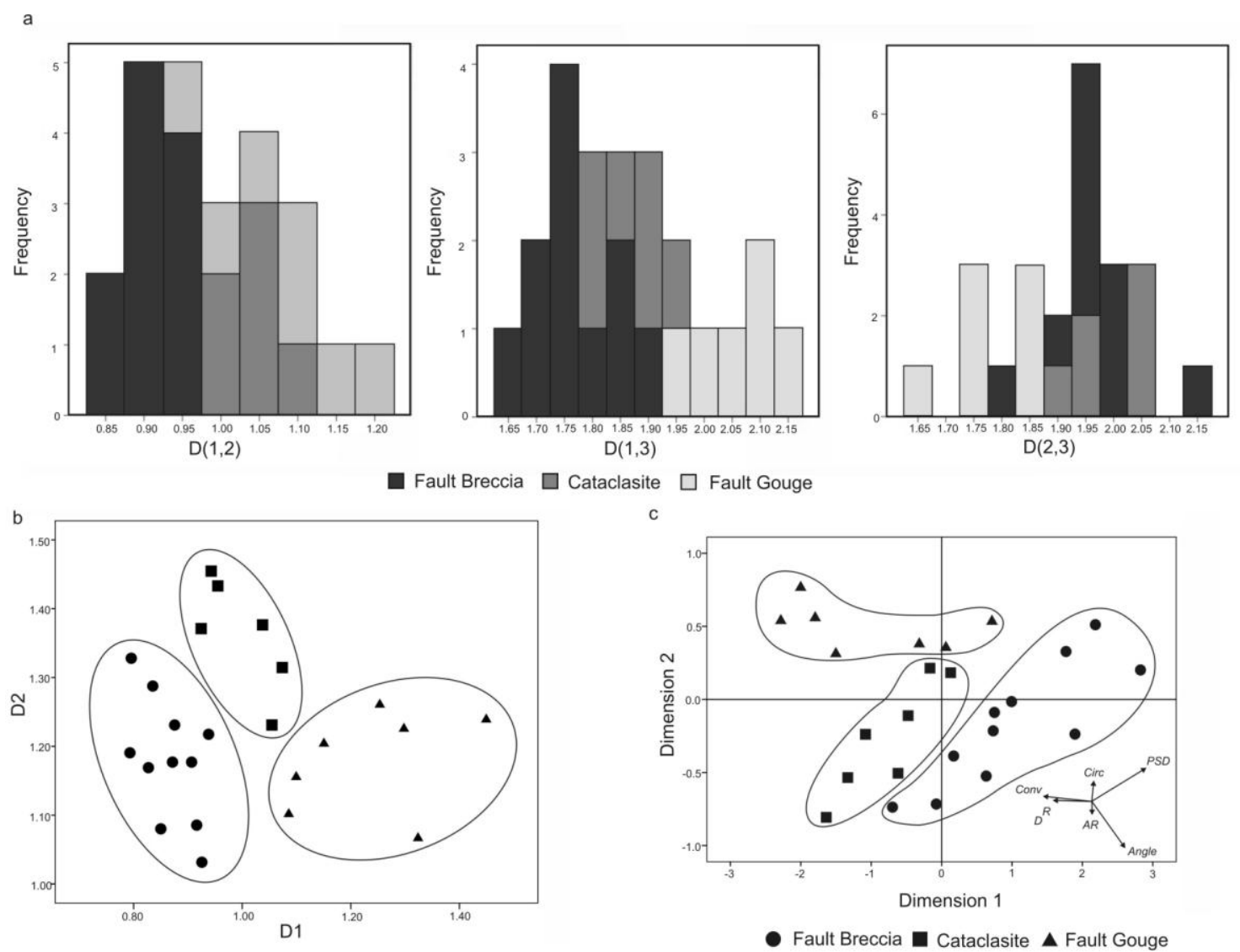

Figure II.8: a: Histograms of discriminant functions D(1,2), (2,3), (1,3). In D(1,2) group 3 is close to group 2, in $D(2,3)$ group 1 to group 2, while in $D(1,3)$ group 2 to group 3. b: The plot of D1 and D2 discriminant functions, showing clear separation of tectonite types, implying a proper classification of 
these groups by the combination of their geometric parameters. $c$ : The two dimensional projection of multidimensional-scaling. The vectors indicate the direction and strength of the parameters in the multidimensional space. The groups of breccias and cataclasites reflect relatively similar tendencies, meaning they are determined by the same geometric parameters. The fault gouges have significantly different characteristics in their geometric properties.

These results indicate that cataclasites can be separated from the other two tectonite types mainly by their $A R$ values. In addition to this, the strong role of the Angle and $P S D$ data in function $\mathrm{D}(1,2)$ emphasise their importance in differentiation between breccias and cataclasites, while the Circ values have high weight in the distinction of gouges from the other two groups. Angle data are participating in all of three discriminant functions, indicating their importance in the separation of tectonites with every degree of deformation. Beyond the obvious predictions of discriminant functions $\mathrm{D}(1,2)$ and $\mathrm{D}(2,3)$ (gouges are grouped as cataclasites, instead of breccias and breccias are grouped as cataclasites instead of gouges), the results of $\mathrm{D}(1,3)$ indicate that the cataclasites are generally more similar to breccias than to gouges.

In the following, the three groups of tectonites were compared to each other by calculating the following D1-D2 discriminant functions (Fig. II.8/b):

$$
\begin{gathered}
\mathrm{D} 1=0.731 * P S D-0.588 * \text { Angle }+0.553 * \text { Circ } \\
\mathrm{D} 2=0.974 * A R+0.94 * P S D-0.271 * \text { Circ }
\end{gathered}
$$

According to the significance test of the D1-2 functions (Table II.3/c,d), both of the roots (the eigenvalues of the functions) add significantly to the classification. The larger proportion of the variance is related to $\mathrm{D} 1(82.7 \%, \mathrm{D} 2: 17.3 \%)$, and the functions have a fairly good canonical correlation (D1: 0.917, D2: 0.725). High prediction accuracy was obtained from cross-validation of the prediction model: $95.8 \%$ of the cases were classified correctly. In the D1 function, the PSD has 
the highest weight, followed by Angle and Circ values. As the D1 values remarkably increase in parallel with the petrographically observed deformation, this indicates that these parameters are the markers of the degree of deformation, while the three other factors $\left(D^{R}, \operatorname{Conv}, A R\right)$ have subordinate roles. This also means that the measured PSD dimensions reflect a connection with the observed deformation, in accordance with the results of earlier authors (Sammis et al., 1986, 1987, Blenkinsop, 1991, Storti and Balsamo, 2010), who pointed out that the increasing deformation manifests in an increasing number of relatively smaller particles, which results in a higher $D^{S}$ dimension.

In connection with the role of $P S D$ values, it is important to reveal the relationship between the two measured scales. From the aspect of comparison of mechanical behaviour of the meso- and micro-scale samples, there is a strong difference according to the fragmental properties by the PSD values. The significantly lower $D^{S}$ values of core samples can be the result of the weaker deformation, while the high values of micro-scale samples suggest strong fragmentation. The values considering macro- and micro-scale representing the same depth interval show an abrupt change in the tendency of $P S D$ values, between grain sizes of 0.4 and $0.7 \mathrm{~mm}^{2}$, suggesting a mechanism change. This could be in connection with the entrance of single-mineral phases, as the particle size reduction reached the level of micro-scale clasts. The PSD values imply the mechanical strength of the particles in the order of rock fragments $\rightarrow$ polycrystalline quartz $\rightarrow$ feldspar $\rightarrow$ monocrystalline quartz. These results, with the abundance of monocrystalline quartz grains in the most deformed fault gouge samples, coincide with the earlier studies regarding the strength of quartz particles (Heilbronner and Keulen, 2006).

The parameter Circ also has a high weight with regard to D1 function, implying that its values increase in parallel with the progressive deformation. The evolution of higher Circ values in the intensely deformed samples can be the result of the gouge formation, which was strengthened by numerous earlier papers (Engelder, 1974, Storti et al., 2007, Storti and Balsamo, 2010); chipping, rounding and abrasion result in a more circular outline on the clasts in the fault gouges. All of these 
processes abrade the sharpest parts of the grain boundaries due to the intensive particle interactions.

The Angle values have strong negative weight in the D1 function. This implies that the developing orientation (the decreasing relative standard deviation of the long-axis angle values) evolves in parallel with the increasing deformation, as the previous, chaotic structure is replaced by a more oriented fabric. This implies that the angles of particle's long axes have lower scattering, by accepting the statement that the long axes reflects the orientation of a single clast, according to the evolution Grain Shape-preferred Orientation (GSPO) (Cladouhos, 1999).

The discriminant function D2 is strongly determined by the $A R$ and - just like in D1 - PSD values, while the Circ has a lower role; in contrast, the other three $\left(D^{R}, C o n v\right.$, Angle $)$ parameters are subordinate. As D2 function clearly separates cataclasites, this implies that the $A R$ has a strong role in their identification, together with the previously mentioned PSD data.

The strong role of $A R$ values, especially in cataclasite samples, is probably connected to the propagation of the shear-parallel fractures. This has previously been reported as a specific sign of the evolving cataclastic texture, where the emerging orientation is usually marked by the direction of the elongated grains, resulting in grain shape-preferred orientation (GSPO) (Tanaka, 1992). The reduction of $A R$ in the most deformed samples could be the result of the above mentioned rounding related to the gouge generation (chipping, abrasion, fracture propagation perpendicular to the shear plane), where wear of the clasts favours the formation of particles with a more isometric shape (Storti et al., 2007). The parameters not mentioned $\left(D^{R}\right.$ and the Conv) have only limited roles in both discriminant functions, which means that either they are not able to distinguish tectonites or their role can be expressed more properly by the combination of other parameters. Aside from their relatively weak role in the discrimination of different tectonites, it is necessary to detail their possible tendencies in a few words.

According to the earlier studies (e.g. Jébrak, 1997), there is a good correlation between $D^{R}$ dimensions and the intensity of the chemical alteration processes. In this case, from the micro-scale samples - by the $D^{R}$ results - the breccias suffered the strongest fluid-rock interaction, while the 
fault gouges - with the transitional values of cataclasites - show the lowest $D^{R}$ dimensions. The most intensely deformed fault gouge clasts, which are mainly composed of monocrystalline quartz, seemingly do not favour strong fluid-rock interactions, which is in contrast to the less deformed particles. The changes in Conv data do not/only slightly correlate with lithological types. These results imply that the chemical resistivity of the clasts increases in parallel with the deformation.

The extremely different values of meso- and micro-scale $D^{R}$ data raise the question about their possibly distinct origin. According to Lalonde et al. (2010), these two, strongly dissonant groups of $D^{R}$ dimensions can be derived from the action of different reactions, namely, the diffusion limited-regime and the kinetic regime, respectively. The diffusion limited-regime acts at a thin section scale, while the scale kinetic regime is more characteristic in core sample clasts (Jébrak, 1997, Lalonde et al., 2010). The diffusion-limited regime is governed by the diffusion rate of the reactants, and only the most exposed parts of the solid (such as the corners) are reached by these reactants. This regime therefore leads to a relative smoothing of the external grain surfaces (Lalonde et al., 2010), especially in thin section scale samples, where single mineral particles are abundant. The kinetic regime is characterised by a consumption rate that is limited only by the chemical reaction rate. The concentration of the reactants is the same everywhere and the external surface of the solid is totally exposed to the reactants, leading to a progressive increase in the clastcomplexity (Lalonde et al., 2010); this is visible in the rock-fragment dominant meso-scale samples.

In the following, the relative positions of the samples in the theoretical six-dimensional space of the measured geometric parameters were computed using the multidimensional-scaling algorithm in order to reveal their possible relationships (Fig. II.8/c). The calculated twodimensional projection clearly illustrates the relative spatial position, as well as evolution trends of the different tectonites. Both breccias and cataclasites reflect significant variability along the same direction. This direction is defined by the projected axes of AR, PSD and Angle parameters, while other parameters have close to constant values or reflect relatively low changes along this direction. In contrast, fault gouge samples change along a direction almost perpendicular to the previous 
orientation, which is marked by the theoretical directions of PSD and Circ values. This implies that the groups of breccias and cataclasites are defined by the same parameters, while the fault gouges show characteristically different evolution, which is visible in their different determining parameters.

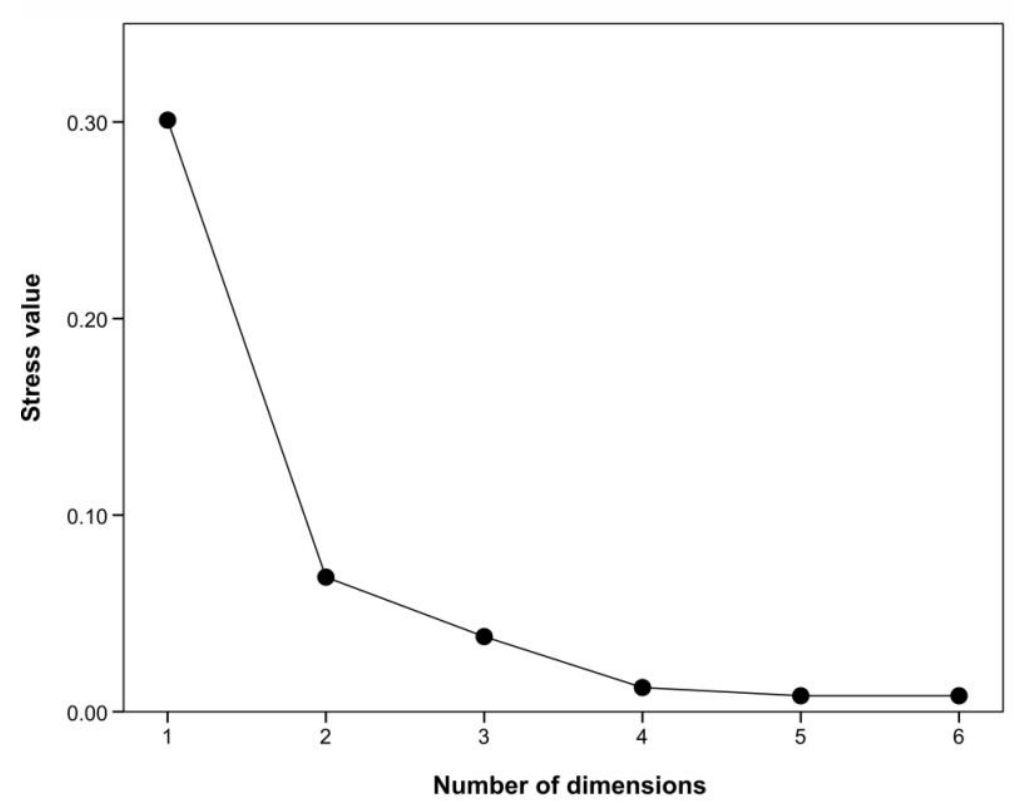

Figure II.9: Scree plot of the multidimensional-scaling. The plot of the stress values and the dimensions imply that the addition of the first four dimension (with PSD, Angle, AR, and Circ parameters) add significantly to the model.

The scree plot resulting from the multidimensional-scaling is illustrated on Figure II.9. Important feature of the plot is the steep decreasing in stress values during the addition of the first four dimensions. The process is followed by shallowing of the slope, which indicates the four dimensional solution of the multidimensional-scaling. This flat stage reveals that the effect of the fifth and sixth dimension is negligible as these provide only minimal improvement to the validity of the model (e.g. decreasing in the stress value). All these observations on the position and structure of the axes point out that the relative position of the samples can be defined by their $A R, P S D$, Circ and Angle values. 
By the statistical evaluation of the three tectonite groups and the marking of important distinctive geometric parameters, the pathway of deformation and the related mechanisms can also be identified (Fig. II.10). Directions of progressive fault rock evolution are inferred from the microstructurally defined order in the degree of the fragmentation of micro-scale samples. The initial deformation is marked by the progressive evolution of breccias, which is observable most characteristically by the increasing $A R$ values coupled with chaotic fabric giving a typical weakly disaggregated, coarse fault breccia texture. This can mark the mechanism of the initial fragmentation, which is primarily visible in their increasing elongation (along Process 1). The slightly decreasing PSD values along the Process 1 imply that this parameter has only a subordinate role in the evolution of fault breccias. The fragmentation - marked by the PSD - possibly becomes an important factor in the advanced stages of deformation. The onset of comminution and cataclastic deformation is marked by the appearance of increasing GSPO with clast elongation as a result of shear-parallel fracture-propagation.

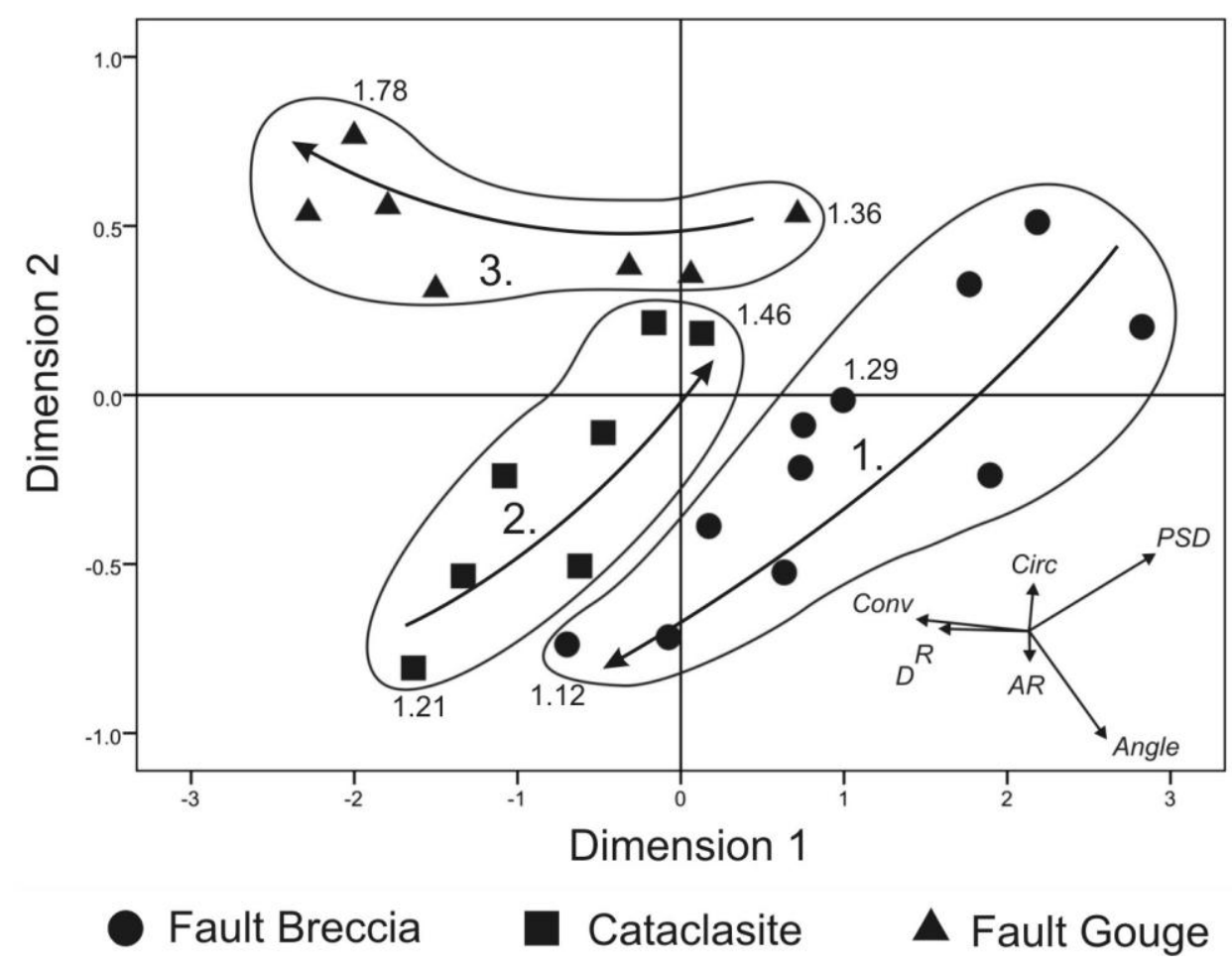

Figure II.10: Possible evolution of different tectonites by their geometric parameters. Process 1: initial 
fragmentation of the breccias, 2: onset of cataclastic flow and comminution, 3: gouge forming by chipping, abrasion and rounding of particles and intensive grain size reduction. Numbers denote the extreme PSD values for each group.

The result of multidimensional-scaling demonstrated that the increasing intensity of cataclastic flow (comminution, clast rotation, micro-fracturing and sliding along these fracture planes with locally anastomising texture (Hirono et al., 2008)) leads to a more oriented structure, marked by a decrease of the Angle values. Prevailing surface abrasion, chipping and grinding in the cataclasites tend to decrease the $A R$ values as a result of the presence of fractures perpendicular to the shear plane, which is visible in the parameter changes along Process 2 . This process transforms to fault gouge formation (Process 3) through the development of a strongly oriented structure with progressively increasing $P S D$ values, the dominantly rounded particles and the evolved GSPO. The totally comminuted texture of fault gouges reflects a distinct group with regard to their geometric parameters in comparison with the two earlier groups: according to the statistical evaluation of PIA data, the breccias and the cataclasites have strong connection in the evolution of their geometric properties (although there are parameters which are able to distinguish them), while fault gouges follow clearly different trends in the clast geometric data.

\section{II.5.2 Possible effects of clast geometry on hydraulic properties}

The observed petrographic and clast geometric parameters indicate that there is presumably a strong connection between particle size/shape and the fluid flow properties of fault zones.

Angular particles inhibit rolling and mainly deform by stick-slip motion, fragmentation, and dilatation (Blenkinsop, 1991), resulting in weakly disaggregated angular rock-fragments. According to Storti et al. (2007), the abundance of coarse, angular clasts may maintain enhanced transmissibility by protecting the pore spaces between the fragments. In contrast, the rounded fault 
gouge particles resulting from comminution accommodate shear by the low-friction mechanism of rolling (Hecht, 2000; Storti et al., 2007). This mechanism results in stable-sliding tendencies in these localised zones, which implies a fault weakening behaviour and - via positive feedback between the gouge generation and the strain localisation - an increasing concentration of displacement.

From the perspective of reservoir properties, the fluid flow behaviour of the examined fault zone is under the control of gouge-bearing fault core layers. The strain localisation can protect the elevated porosity and permeability of the coarse breccia-bearing zones compared to the undeformed protolith. In contrast, thin gouge layers usually have extremely weak fluid flow properties, which can result in the compartmentalisation of the hydraulic regimes in the fault zone (Caine et al., 1996).

\section{II.6 Conclusions}

According to the measured parameters (PSD, D $R$, AR, Circ, Conv, and Angle), their proper usage is able to determine the typical geometric features of different tectonites. In order to distinguish fault rocks based on their clast geometric attributes and to reveal the main mechanisms of deformation, multivariate statistical methods were applied. The discriminant function analysis defined the appropriate combination of parameters for the separation of different tectonites and pointed out the relatively similar geometric features of fault breccias and cataclasites in contrast to the significantly different characteristics of fault gouges. The multidimensional scaling demonstrated a three-phase evolution of the analysed brittle and semi-brittle tectonites, reflecting strongly distinct deformational pathways in each stage. The importance of parameters according to their weight in the applied functions were the following, in descending order: PSD, Angle, AR, and Circ. Application of the above methods separates the fault rocks with diverse petrophysical 
properties and also provides an opportunity to extend microstructural information gained at borecore-scale to spatial data, which can provide answers on the overall behaviour of the fault zone. 
Chapter III.: Integrated petrographic - rock mechanic borecore study from the metamorphic basement of the Pannonian Basin, Hungary

Manuscript accepted by the Open Geosciences on October 13, 2014

\section{Authors:}

László Molnár

Department of Mineralogy, Geochemistry and Petrology, University of Szeged, Hungary

Balázs Vásárhelyi

Department of Structural Engineering, Pollack Mihály Faculty of Engineering, University of Pécs, Pécs, Hungary

Tivadar M. Tóth

Department of Mineralogy, Geochemistry and Petrology, University of Szeged, Hungary

Félix Schubert

Department of Mineralogy, Geochemistry and Petrology, University of Szeged, Hungary 


\title{
Integrated petrographic - rock mechanic borecore study from the metamorphic basement of the Pannonian Basin, Hungary
}

\begin{abstract}
The integrated evaluation of borecores from the Mezősas-Furta fractured metamorphic hydrocarbon reservoir suggests significantly distinct microstructural and rock mechanical features within the analysed fault rock samples. The statistical evaluation of the clast geometries revealed the dominantly cataclastic nature of the samples. Damage zone of the fault can be characterised by an extremely brittle nature and low uniaxial compressive strength, coupled with a predominanate coarse fault breccia composition. In contrast, the microstructural manners of the increasing deformation coupled with higher uniaxial compressive strength, strain-hardening nature and low brittleness indicate a transitional interval between the weakly fragmented damage zone and strongly grinded fault core. Moreover, these attributes suggest this unit is mechanically the strongest part of the fault zone. Gouge-rich cataclasites mark the core zone of the fault, with their widespread plastic nature and locally pseudo-ductile microstructure. Strain localization tends to be strongly linked with the existence of fault gouge ribbons. The whole fault zone with $\sim 15 \mathrm{~m}$ total thickness can be defined as a significant migration pathway inside the fractured crystalline reservoir. Moreover, as a consequence of the distributed nature of the fault core, it may possibly have a key role in compartmentalisation of the local hydraulic system.
\end{abstract}

Keywords: fractured metamorphic reservoir, rock mechanical parameters, fault rocks, brittle deformation 


\section{III.1 Introduction}

Brittle fault zones of crystalline rock masses can serve as migration pathways or also as sealing surfaces for fluid flow in the Earth's crust, so the understanding of their internal structure is crucialfor interpreting hydraulic systems. Earlier studies (Caine et al., 1996, Evans et al., 1997) on the architecture of fault zones defined two main structural elements: first, a weakly disaggregated, densely fractured "damage zone" and a strongly deformed and fragmented "fault core", where the pre-existing rock fabrics were erased by fault development. These elements can be characterised by the formation of diverse tectonite types (fault breccias, cataclasites, fault gouges), which often also possess quite heterogeneous rheological features. Consequently, the petrological, petrophysical and rock mechanical properties may have an extremely heterogeneous spatial distribution in the fault zones.

In addition, evaluation of tectonites from core samples always provide a serious challenge to proper structural interpretation, particularly due to the small number of borecores and their quite doubtful representativeness of the whole rock mass (Ben-Zion and Sammis, 2003). These constraints raise the necessity of integrated analytical methods with that aim to gain as much information from these samples as possible.

The main aim of this paper was to present the results of one such petrographic, microstructure and rock mechanical analysis: we examined the lithological and rheological attributes of a basement fault zone with a quite high rate of core recovery and abundant amount of available samples, via the usage of these integrated methods. The combined petrographic (microstructural and clast geometric) and rock mechanical evaluations were conducted partly to clarify the role of main structural elements in the hydraulic system of both the fault zone and the whole fractured rock mass. 


\section{III.2 Geological setting}

The locality of this study, the pre-Neogene basement of the Pannonian Basin (PB), which is part of Alpine-Carpathian-Dinaric orogenic belt, and which consists of deep sub-basins separated by subsurface topographic highs of metamorphic basement (e.g., Tari et al., 1999, M. Tóth, 2008). One of the best-known elevated basement highs is the Mezösas-Furta Dome (MFD), which is part of the series of metamorphic highs bordering the Békés Basin to the north (Fig. III.1).

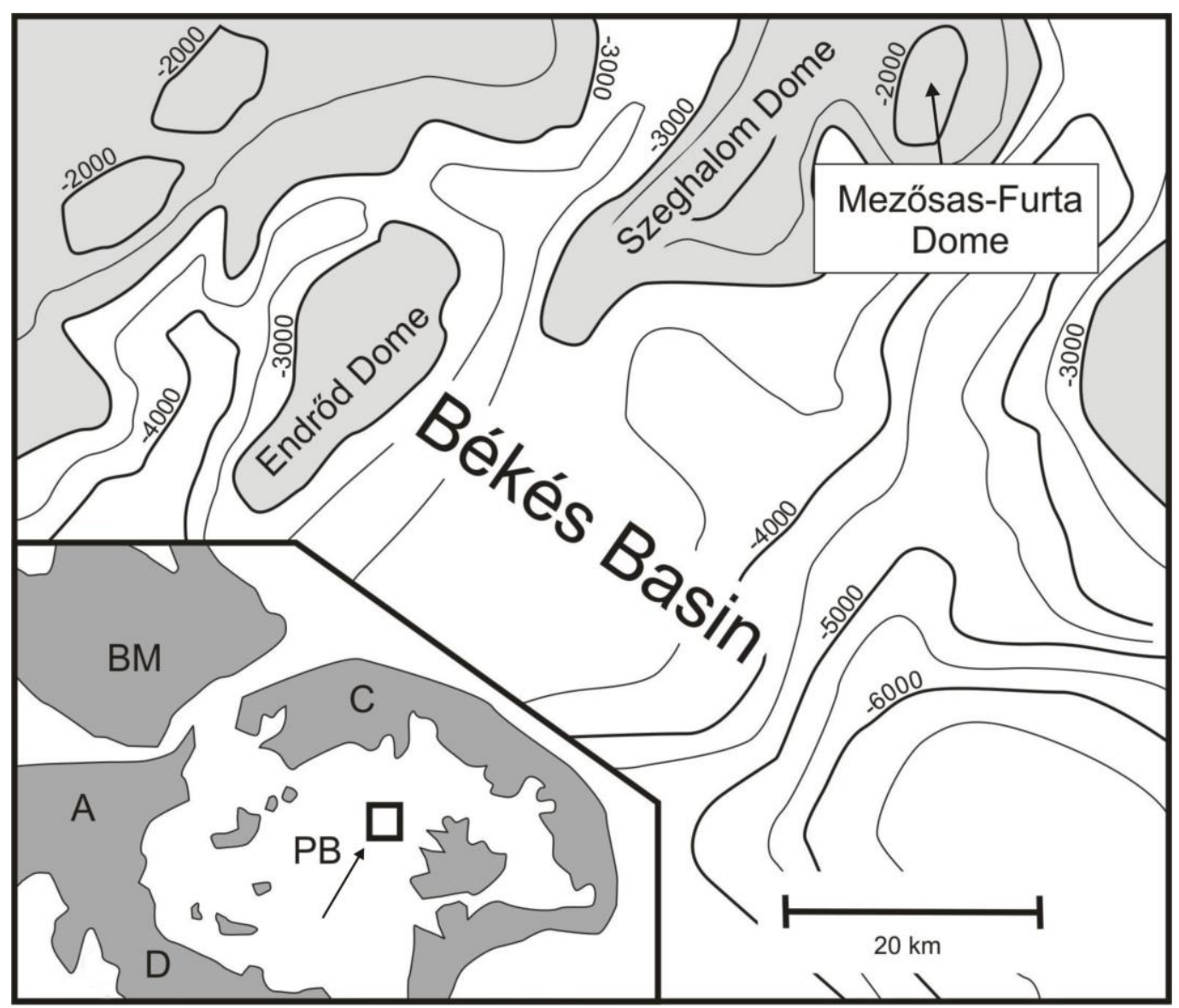

Figure III.1: Topographic map of the Pre-Neogene basement of the eastern part of the Pannonian Basin and the distribution of the basement highs (shaded). Isolines denote depth below the present surface in meters. Inset: Location of the studied well in the Alpine-Carpathian-Pannonian System. A - Alps, BMBohemian Massif, $C$ - Carpathians, D - Dinarides, $P B$ - Pannonian Basin 
Following the earliest studies on the area (e.g. Balázs et al., 1986 or Szili-Gyémánt, 1986), detailed petrological investigations of M. Tóth and Zachar (2006) defined the metamorphic evolution of the most typical lithologies of MFD and clarified their spatial arrangement through the basement high. The constructed idealized rock column suggests the presence three lithological blocks: at the uppermost structural level amphibolite and amphibole-biotite gneiss (AG group) with medium grade metamorphism is common. This group structurally overlys high metamorphic grade sillimanite and garnet bearing biotite gneiss that is often coupled with garnet-bearing amphibolite, and is jointly is named as SG group. At the lowermost structural position orthogneiss is dominant, derived from a medium-grade metamorphism of an igneous intrusion. The orthogneiss body is often cross-cut by microgranite dykes. These lithologies are jointly named the OG group. The rather different metamorphic evolutions of these groups and the presence of wide shear zones along the group boundaries indicate these blocks were juxtaposed following their metamorphic pressuretemperature peaks.

According to M. Tóth and Zachar (2006) in the central range of the dome the SG and AG units dominate on top of the basement, while the northern slope of the MFD is mainly built up by the OG unit. By the interpretation of these spatial data, the structure of the area can be explained as overthrusted NW-SE oriented stripes of AG/SG/OG triplexes. The simplified framework of the MFD can be described by parautochthonous OG unit with allochthonous AG/SG duplexes on the top. Details of microstructural investigations indicate that AG/SG boundary formed during an earlier compressional event and the two groups jointly overthrust the OG unit. These statements are in good agreement with the results of numerous authors (Albu and Pápa, 1992, Tari et al., 1999), as the structure of the basement was strongly affected by Upper Cretaceous nappe formation, as well as sinistral transpression in the Middle Miocene period. This scenario was complicated on the southeastern portion of MFD, where high-angle normal faulting related to the Neogene (Badenian) extension of the area formed horst-graben structures. 
The multi-stage tectonic evolution of the area resulted in the presence of wide brittle fault zones throughout the crystalline highs, which also act as fractured hydrocarbon reservoir in the basement of the PB, with the MFD reservoir being one example. By the inferences of M. Tóth (2008), these fractured horizons with their often-enhanced permeability, have a great impact on the hydraulic system of the metamorphic highs, and in fact these shear zones probably serve as the main migration pathways between the deep sedimentary basins and the fractured hard rock realm (M. Tóth, 2008). A wide fault zone was penetrated by a well (A-2) in the northern, OG-dominated part of MFD with a quite high core recovery (Fig. III.2). The well is situated north of the hydrocarbon producing wells of the field in the most elevated parts of the metamorphic high (unpublished industrial data). Although, well A-2 itself is non-productive due to its structural position, the sampled fault zone may play a crucial role in the local petroleum system by linking the source rocks of the adjacent sedimentary sub-basins and the metamorphic high. In the absence of oriented borecores, high resolution seismic sections or nearby wells, the kinematic sense and the spatial position of the approximately 10 meters wide fault zone are unclear. Nevertheless, the examined section that consists of diverse fault rock samples gives an outstanding opportunity for an integrated evaluation of the shear zone. 
Figure III.2: a: Detailed sub-surface topography of Mezösas-Furta Dome. Dots mark the productive wells of the field, while dashed line indicates the assumed location of the main hydrocarbon accumulation. Isolines denote depth below the present surface in meters. $b$ : Schematic vertical section of the investigated well and borecores evaluated in this study. The grey rectangles indicate the location of the samples.

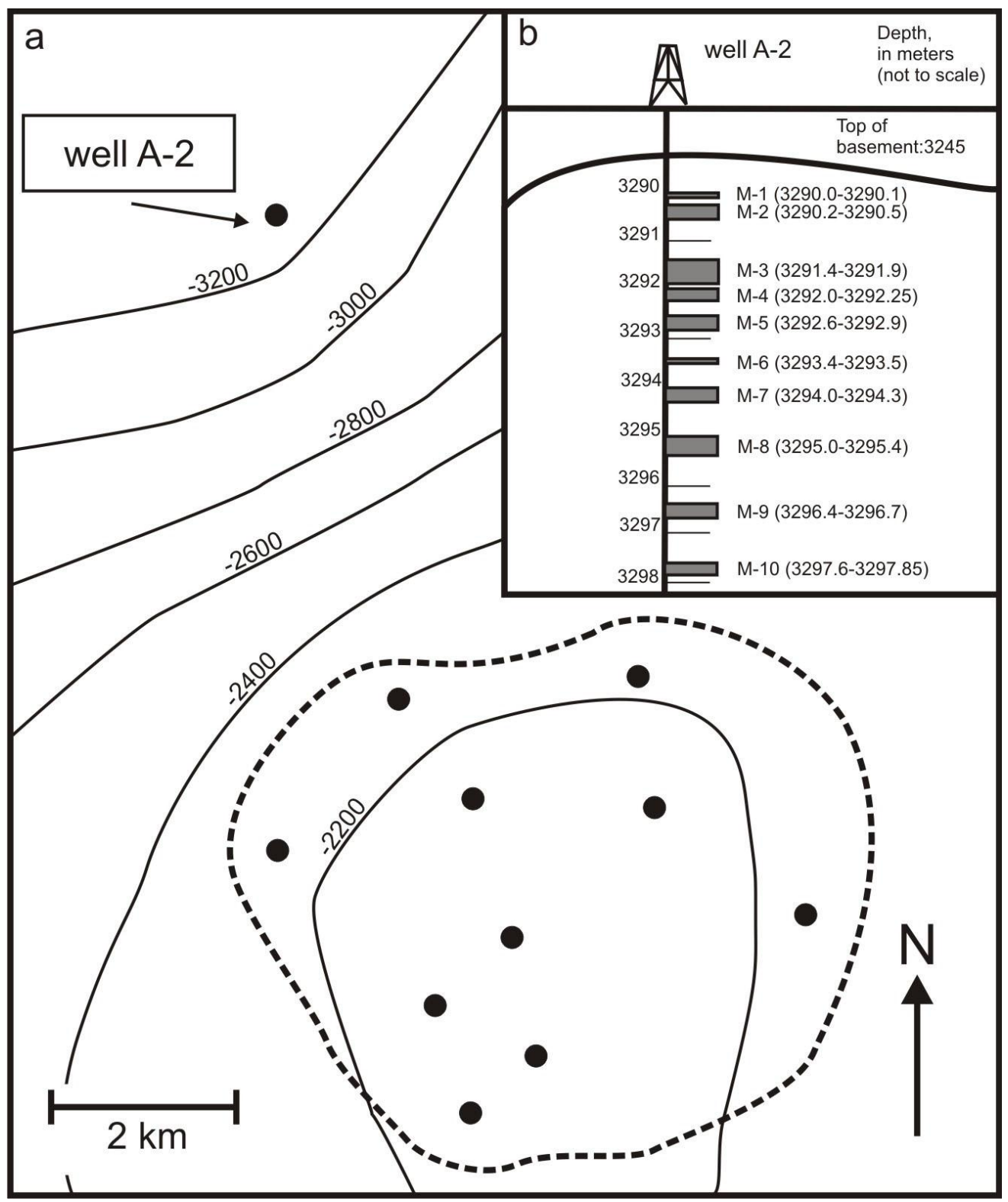




\section{III.3 Samples and applied methods}

\section{III.3.1 Available samples}

All 10 available borecores from the well A-2 were sampled in the depth interval between 3290 and 3297.85 meters below sea level with high core recovery (detailed in Fig. III.2/b). All of the rock specimens were affected by various degrees of brittle deformation. The cores were not oriented. For Petrographic Image Analysis of the fault rocks, 78-414 clasts were measured from each sample.

\section{III.3.2 Petrographical and microstructural observations}

Following the preliminary macroscopic analysis, thin sections were evaluated from all 10 borecores for the petrographic investigations to define the microstructural characteristics of the diverse fault rock types. The available thin sections were made perpendicular to the foliation and parallel to lineation.

\section{III.3.3 Description of Petrographic Image Analysis (PIA)}

The PIA of samples was conducted with the aim of defining the geometric features of clasts within the fault rocks. First, polished surfaces were cut parallel to the longitudinal axis of the borecores, then 2D images were taken (Fig. III.3). Unfortunately, as some of the available thin sections did not a provide statistically sufficient amount of observable particles ( $>50$ clasts), the micro-scale samples were omitted from the image analysis. The lower limit of the image analysis

was 100 pixel $^{2}\left(0.16 \mathrm{~mm}^{2}\right)$, according to the suggestions of (Bérubé and Jébrak, 1999, Clark et al., 
2006) on the methods of particle size/shape analysis, while the size of the largest measured clast was 193960 pixel $^{2}\left(293 \mathrm{~mm}^{2}\right)$. However, in this case the clasts could not be segmented by the use of a colour threshold application as the matrix or cement was too heterogeneous, so the selection of edges was accomplished manually, using the "Magnetic Lasso" tool of Adobe Photoshop. The clast geometric measurements were completed using the selected parameters in ImageJ. The applied parameters are discussed below.
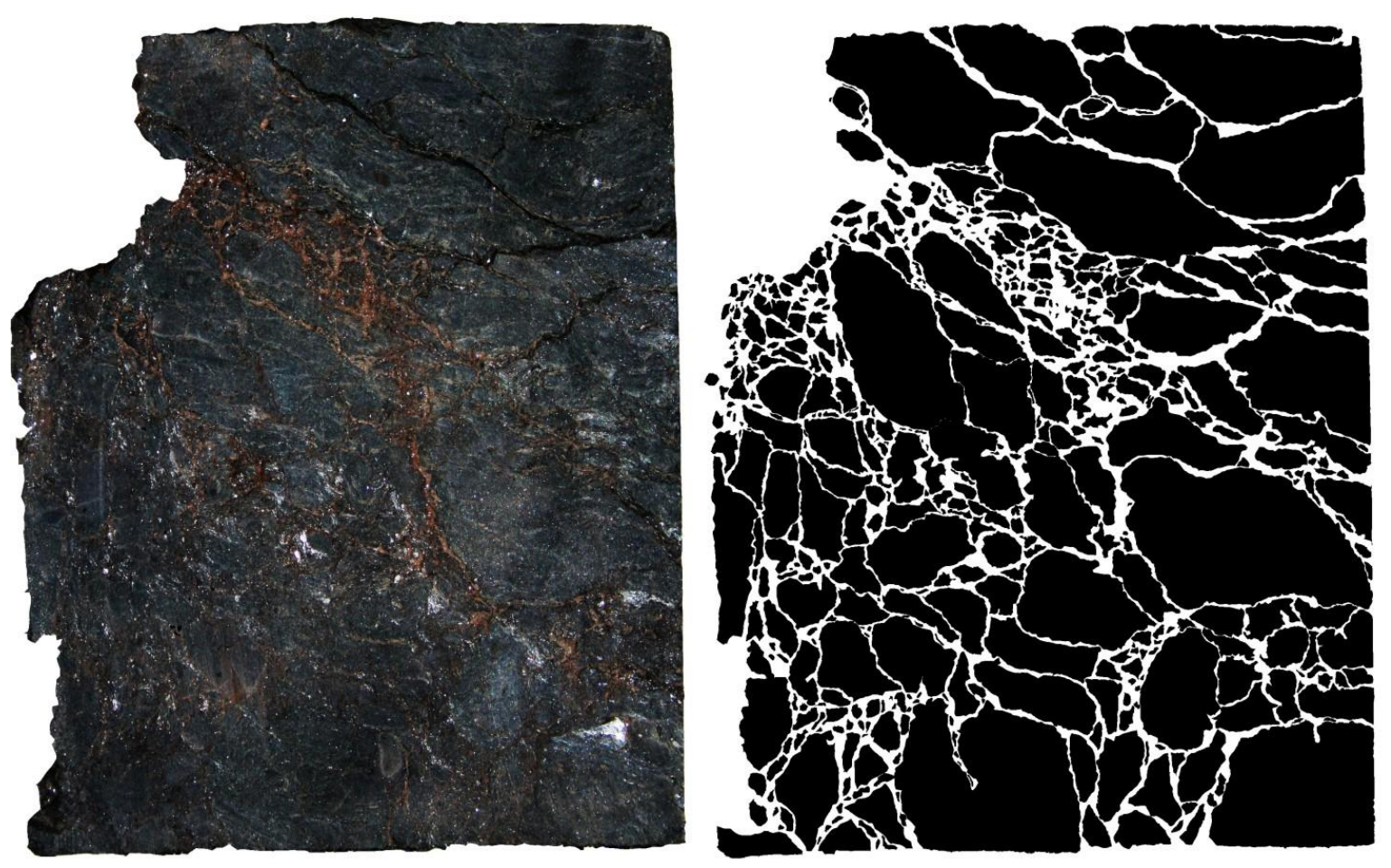

Figure III.3: Polished surface of a borecore from well A-2 (sample M1) and the clasts selected for the measurements, drawn one-by-one in Adobe Photoshop. The diameter of the borecore is 6.5 centimeter.

\section{III.3.3.1 Particle Size Distribution (PSD)}

Earlier studies (Sammis et al., 1986, 1987, Blenkinsop, 1991) demonstrated the fractal nature of the cumulative $P S D$ of the fault rocks, with the following equation: $N(s) \sim s^{-D^{S}}$. The $N(s)$ is the number of particles smaller than a size $s$ (square root of the area), while $D^{S}$ can be determined as the slope of the best fit line on a $\log N(s)$ against $\log s$ graph. Different $D^{S}$ values are expected for 
varying degrees of the fragmentation process and different tectonic settings or rock types, according to the data of Sammis et al. (1987), Blenkinsop (1991), Storti et al. (2003) and Keulen et al. (2007) (Table III.1.).

\begin{tabular}{|c|c|c|c|}
\hline Authors, year & Rock type & NaturaVexperimental deformation & 2D fractal dimension \\
\hline Sammis et al., 1987 & Granite & Natural & 1.6 \\
\hline Blenkinsop, 1991 & Granite, gneiss & Natural & $0.8-2.1$ \\
\hline Blenkinsop, 1991 & Arkose & Natural & $1.6-2.0$ \\
\hline Storti et al., 2003 & Carbonates & Natural & $0.9-2.5$ \\
\hline Keulen et al., 2007 & Granitoids & Experimental & $1.6-2.4$ \\
\hline Keulen et al., 2007 & Granitoids & Natural & $1.4-2.3$ \\
\hline This study & Gneiss & & $1.12-1.72$ \\
\hline
\end{tabular}

Table III.1: Published grain size distribution data of brittle fault rocks, based on the results of Sammis et al.(1987), Blenkinsop (1991), Storti et al. (2003), Keulen et al. (2007).

\section{III.3.3.2 Clast complexity $\left(D^{R}\right)$}

Based on the results of Bérubé and Jébrak (1999), "Fractal Dilation" is the most precise method for the determination of clast complexity. The "Fractal Dilation" macro of ImageJ uses a 1 pixel-wide outline of the clasts, which are thickened, creating 2, 4, 8 and 16 pixel-width ribbons. The area of these ribbons is plotted against its thickness on log-log plot, where the slope of the best fit line $(S)$ is the indicator of clast-complexity fractal dimension $\left(D^{R}\right)$ using the $2-S=D^{R}$ equation.

\section{III.3.3.3 Aspect Ratio (AR)}

The Aspect Ratio $(A R)$ is the proportion of the long and short axes of the ellipse that best fit the outline of a clast. The ellipse has the same area, long-axis orientation and centre as the original grain, defined by ImageJ.

\section{III.3.3.4 Circularity (Circ)}

The value of circularity can be expressed by the equation of $4 \pi\left(A P / p^{2}\right)$, where $A P$ is the area of the clast, and $p$ is its perimeter (Mort and Woodcock, 2008). This measures how close the 
particle's shape is to a perfect circle. According to the above formula, the value of the Circ varies between 0 and 1, where 0 is an immensely elongated ellipse, while 1 is a perfect circle.

\section{III.3.3.5 Orientation Angle (Angle)}

The numerical value of orientation for a single clast is the angle between the long-axis of the clast's best-fit ellipse and the lateral (the "X") axis of the image. The best-fit ellipse and the longaxis angle are both computed by ImageJ. The degree of orientation is observable in the dispersion from the average Angle values of the clasts, which is numerically manifested in the changes of relative standard deviation values.

\section{III.3.3.6 Convexity (Conv)}

Convexity measures the surface roughness of a particle, calculated by dividing the convex hull perimeter by the actual particle perimeter, so the smooth shapes have a Conv value close to 1 , while the spiky and irregular objects have a Conv value closer to 0.

\section{III.3.4 Statistical analysis of the fault rocks}

The brittle fault rock samples were classified by multivariate statistical analysis of their clast geometric parameters (Table III.2/a). The method (detailed in Chapter II.) was developed and tested on the fault rocks of the nearby Szeghalom basement high, which have a quite similar lithological composition as MFD (M. Tóth, 2008). In this approach, statistically sufficient amount of samples ( 3000 clasts) were measured with the same PIA procedure and their datasets were analysed via multivariate statistical methods (Klovan and Billings, 1976, Davis, 2002). Separation of the three main fault rock types were achieved without any overlapby using two calculated discriminant functions (D1, D2). The calculated discriminant functions were the following, with the weights of the most important parameters: 


$$
\begin{gathered}
\mathrm{D} 1=0.731 * P S D-0.588^{*} \text { Angle }+0.553 * \text { Circ } \\
\mathrm{D} 2=0.974 * A R+0.94 * P S D-0.271 * \text { Circ }
\end{gathered}
$$

\section{III.3.5 Rock mechanical tests}

In accordance with the suggestions of the International Society for Rock Mechanics (ISRM, 2006) regular cylindrical shapes were created with the standard 2:1 (axis: diameter) size and $50 \mathrm{~mm}$ diameter. Only one sample was cut from each borecore due to their limited size. Rock mechanical tests were carried out in the Rock Mechanics Laboratory at the Budapest University of Technology and Economics.

Uniaxial compressive tests, widely used for defining rock mechanical properties, were applied to study the mechanical properties of the samples. If the lateral surface of the sample is traction-free, the experimental configuration can be characterised by the $\sigma_{1}>0, \sigma_{2}=\sigma_{3}=0$ equation. Accepting these statements, the uniaxial compressive strength $\left(\sigma_{\mathrm{c}}\right)(\mathrm{MPa})$ of the samples is derived from the measured uniaxial strain $(\varepsilon)$ and uniaxial stress $(\sigma)$ values. The plot of $\sigma$ against $\varepsilon$ defines the stress-strain curve, where the maximum stress value is the uniaxial compressive strength $\left(\sigma_{\mathrm{c}}\right)(\mathrm{MPa})$. The Young or elastic modulus $(\mathrm{E})(\mathrm{GPa})$ of the samples can be experimentally determined from the slope of the stress-strain curve at $50 \%$ of the ultimate stress, by the advice of ISRM (2006). The Poisson's rate value (v) is the ratio of the axial and lateral strains at this point.

Several characteristic stress levels can be determined through laboratory tests that are essential for understanding the failure (damage) process of brittle rocks during compression:

- $\sigma_{\mathrm{cc}}$ is the crack closure stress level,

- $\sigma_{\mathrm{ci}}$ is the crack initiation stress level,

- $\sigma_{\mathrm{cd}}$ is called the crack propagation stress level. This latter parameter is close to the longterm rock strength (Martin, 1993, Cai, 2010). 
The above three stress levels, i.e., $\sigma_{\mathrm{cc}}, \sigma_{\mathrm{ci}}$, and $\sigma_{\mathrm{cd}}$, show important stages in the macroscopic damage process of intact rocks. Crack initiation starts at stress levels of about $1 / 3$ to $2 / 3$ times the peak uniaxial load $\left(\sigma_{\mathrm{f}}\right)$ for most brittle rocks (Bieniawski, 1967, Cai et al., 2004). The crack propagation stress level $\left(\sigma_{\mathrm{cd}}\right)$ is the stress level at which the total volumetric strain is attained (Cai et al., 2004). It can be calculated from the stress-volumetric strain curve. According to Hucka and Das (1974), the coefficient of brittleness can be calculated as the ratio between the elastic work $\left(\mathrm{W}_{\mathrm{e}}\right)$ and the total or destruction work $\left(\mathrm{W}_{\mathrm{t}}\right)$ during the loading of a specimen until failure. Destruction work $\left(\mathrm{W}_{\mathrm{t}}\right)$ can be calculated from the measured stress-strain curves, as it is defined by the area under the measured stress-strain curve and reveals the amount of energy necessary for the failure of the sample. The elastic work $\left(\mathrm{W}_{\mathrm{e}}\right)$ is also derived from the measured stress-strain curve, but is instead the amount of necessary energy in its elastic stage. The brittleness of samples (B) is the ratio of the elastic and destruction work values $\left(\mathrm{B}=\mathrm{W}_{\mathrm{e}} / \mathrm{W}_{\mathrm{t}}\right)$.

\section{III.4 Results}

III.4.1 Petrographical and microstructural observations

The fault zone of A-2 is mainly composed of cataclasites (Fig. III.4/a), according to microstructural properties of the samples. However, locally other fault rock types are also observable: a coarse breccia without any preferred orientation and the sporadic fault-gouge ribbons occur, which cross-cut the cataclasites.

The internal structure of the cataclasites shows a strongly disaggregated appearance with angular clast geometry, even though macroscopically the external cohesiveness of the cataclasites is more or less remained. The grain size is dominantly under millimeter-scale and the ratio of particles over $2 \mathrm{~mm}$ is under $30 \%$, the limit between the breccia/cataclasite series (Fig. III.4/b,c). Samples 
often have a strong microscopic grain-shape orientation (GSPO) (Passchier and Trouw, 2005): clasts are elongated and their long-axes define the preferred direction. This direction of the GSPO is generally subparallel to the supposed main shear direction. The phenomenon is usually coupled with the manner of cataclastic deformation, namely intensive clast-rotation, comminution and pervasive microfracture propagation (Fig. III.4/c). The particles have a recognizable gneissic precursor with a quartz-feldspar-biotite dominated composition, which is derived from the undeformed wall rock of the OG group. The clasts of cataclasites did not suffer significant chemical alteration, only the largest particles have sporadic clay coating on their edges. The intense deformation often manifests in an anastomising, flow-banded structure with the local appearance of the S-C structures, indicating a semi-brittle style deformation.

Figure III.4: Photomicrographs representing characteristic fault rock textures from the samples of A-2. a: Typical cataclastic texture, which is the most frequent structure of the samples with fragmented and rotated particles (sample M5). b: Strongly deformed domains between the centimeter-scale particles (sample M6). c: Planes of intensified deformation denoted by strongly fragmented cataclastic texture among relatively less deformed coarse grains (sample M4). $d$ : Dilational domain with a weakly disaggregated texture, indicating a characteristic fault breccia texture (sample M2). e: Strongly foliated fault gouge plane with restricted distribution. The foliation is defined by the phyllosilicate flakes (sample M8).f: Granular fault gouge, which is regarded as the location of the largest fault displacement. Note the extremely high matrix ratio, which indicate the comminution of the clasts (sample M10). The scale bars are 500 m long. $\rightarrow$ 

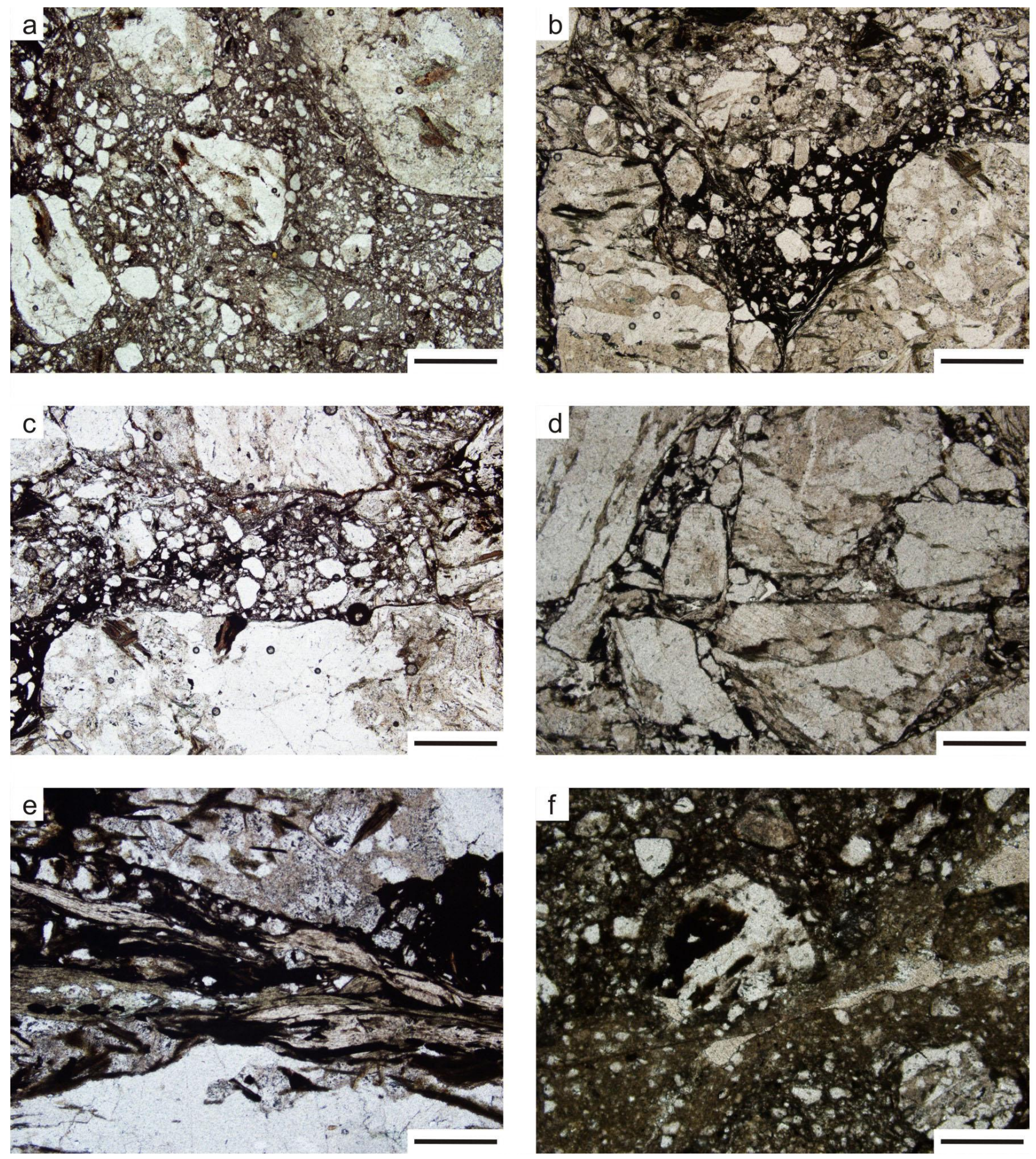

The rather subordinate fault breccia samples mainly consist of coarse grained, angular clasts (often over centimeter-scale) (Fig. III.4/d). The coarse breccia structures are locally prevalent in the samples M1, 2, 3. These samples typically have a chaotic texture often without any structural manner of preferred orientation. The largest clasts often can be fitted along their sharp, dilational edges indicating their mosaic, "jigsaw" type structure (Mort and Woodcock, 2008). The gneissic 
origin of the fault breccia clasts is also recognizable.

In a few cases, the cohesive cataclastic texture is cross-cut by thin, clay-rich layers of incohesive fault gouge, especially in samples $M-5,-7,-8$ and -10 . According to the microscopic investigations, the fault gouge ribbons have a very low clast/matrix ratio, indicating their strongly deformed nature, which is strengthened by the totally fragmented architecture of the clasts (Fig. III.4/e,f). The protolith of the fault gouges is not recognizable, as their particles are mainly composed of mono-crystalline quartz. The comminuted clasts are always embedded in strongly altered clay-rich matrix. Appearance of these planes is restricted to millimeter wide anastomising planes with a sharp boundary towards the relatively less deformed cataclasites.

\section{III.4.2 Clast geometric results}

The clast geometric results with their mode values are summarized in the Table III.2/a. Exceptions are the $P S D$ and the Angle values, as the PSD was calculated from the slope of the grain size curve's best fit line, while the Angle value represents the variation coefficient of the particle's long axis direction in the actual sample.

Elongation of the clasts $(A R)$ of the least deformed, brecciated samples is about $1.5-1.8$, while in the cataclasites slightly higher numbers are typical $(\sim 1.9)$. The highest $A R$ values are observable in the most deformed or gouge-bearing cataclasites, where elongation ratios over 2.0 are frequent, especially in samples M5 and M9. Measurements of clast circularity (Circ) resulted in a slightly decreasing trend from the 0.7 values of less deformed borecores (with M2 as a maximum: 0.75 ) to $~ 0.6$ values in gouge-containing samples (with M10 as minimum: 0.61). Fractal dimensions of particle size distributions $(P S D)$ reflect a gradual, but constant increase towards the more fragmented samples: the lowest value is in the M2 with 1.12 cumulative PSD dimension, and the highest is in M10 with 1.72. In contrast, the numerical manifestation of the clast orientation, the relative standard deviation of the long axis directions is strongly decreasing in harmony with the 
observed intensifying microstructural deformation. The maximum value was calculated for the M2 (0.74), while the minimum is in the M9 (0.42). The clast complexity values reflect rising dimension with observed deformation from the $1.19 D^{R}$ values of M2 to the 1.48 of M8, while the convexity values are generally around $0.85-0.9$, with a lack of any tendency.

\section{III.4.3 Rock mechanical tests}

The results of the uniaxial compressive tests and their derived data are summarized in the Table III.2/b.

In Figure III.5/a, the uniaxial compressive strength results $\left(\sigma_{\mathrm{c}}\right)$ were plotted against the crack propagation stress levels $\left(\sigma_{\mathrm{cd}}\right)$. Our results $(83 \%)$ are in harmony with literature data (ISRM, 2006), which define the onset of crack propagation at $\sim 85 \%$ of the uniaxial compressive strength. The Young or elastic modulus (E) values reflect a good correlation with uniaxial compressive strength results $\left(\sigma_{c}\right)\left(R^{2}=0.93\right)($ Fig. III.5/b), however, samples M4 and M5 were omitted from this plot, due to their strongly characteristic stress-strain curves. From the aspect of the destruction work $\left(\mathrm{W}_{\mathrm{t}}\right)$, samples M4, M5 and M6 have an outstanding high necessary energy amount under the stress-strain curves $(90.34-188.57 \mathrm{~kJ})$ in contrast with other samples, where $50.18 \mathrm{~kJ}$ was the maximum value (M8) (Table III.2/b).

Table III.2: Measured clast-geometric data (a) and mechanical constants (b) of the investigated samples. $\rightarrow$ 

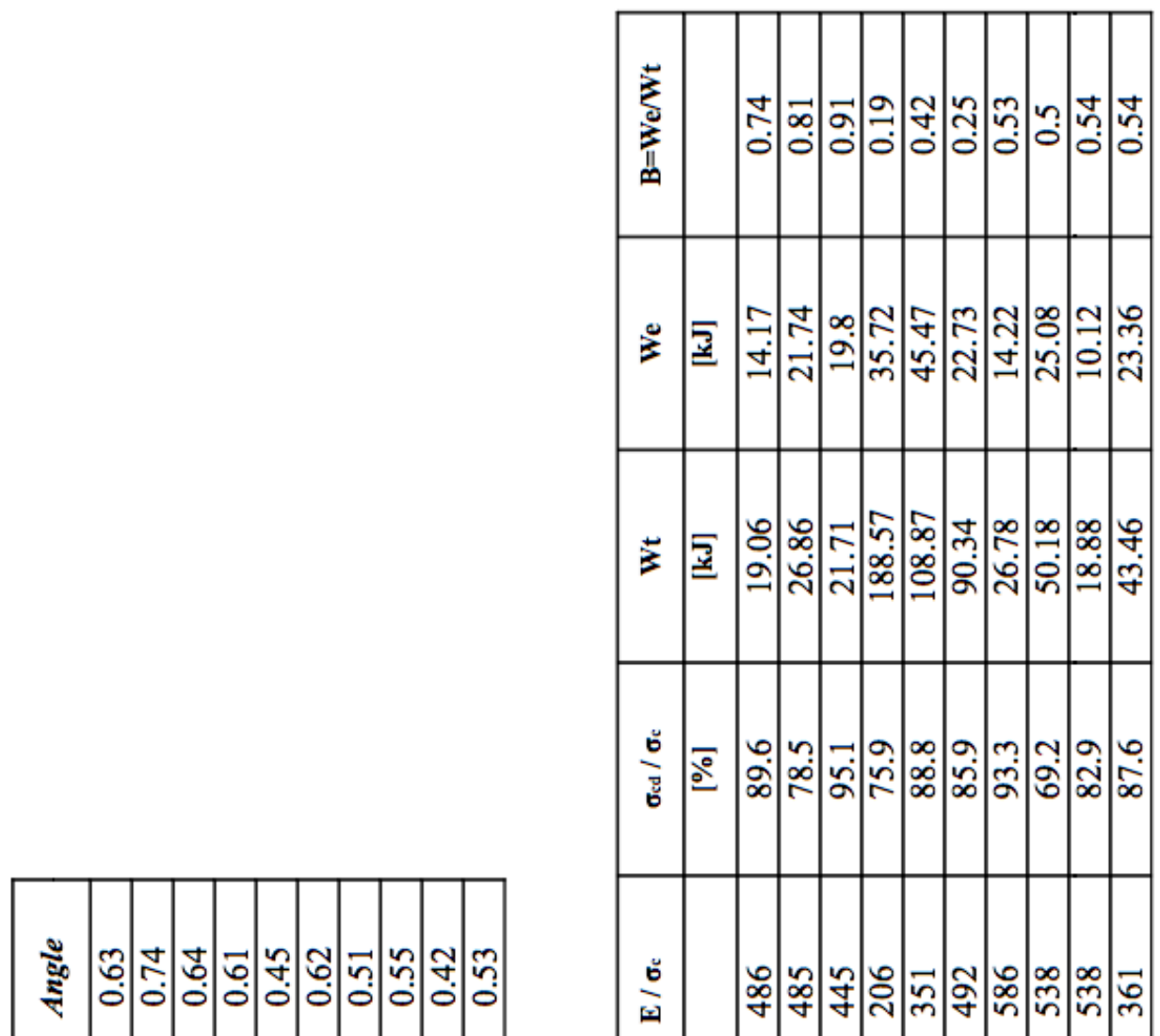

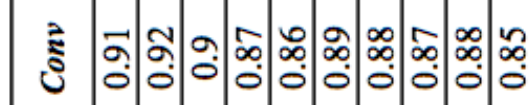

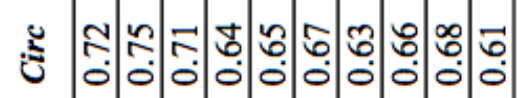

₹

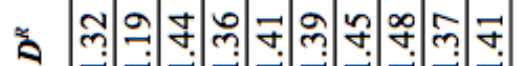

ฉิ

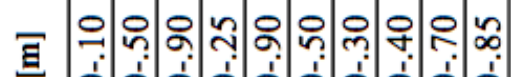

= ठें

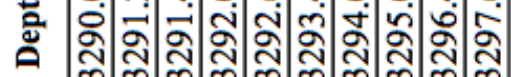

๘ 音

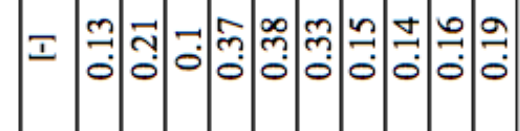

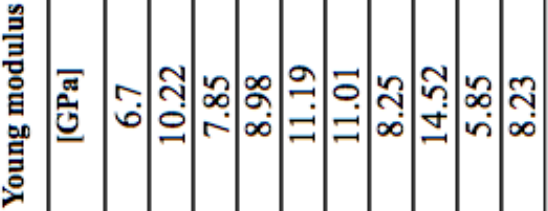

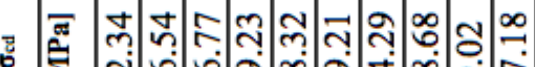

-

జ

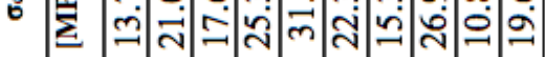

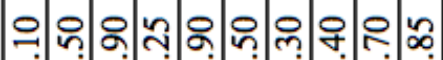

吾 亘

๑ స్లె స్లి స్లిస్లి స్లి స్లి స్లి

م

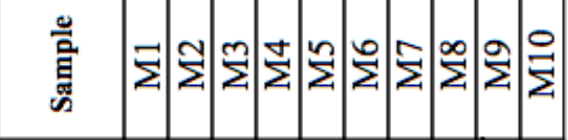




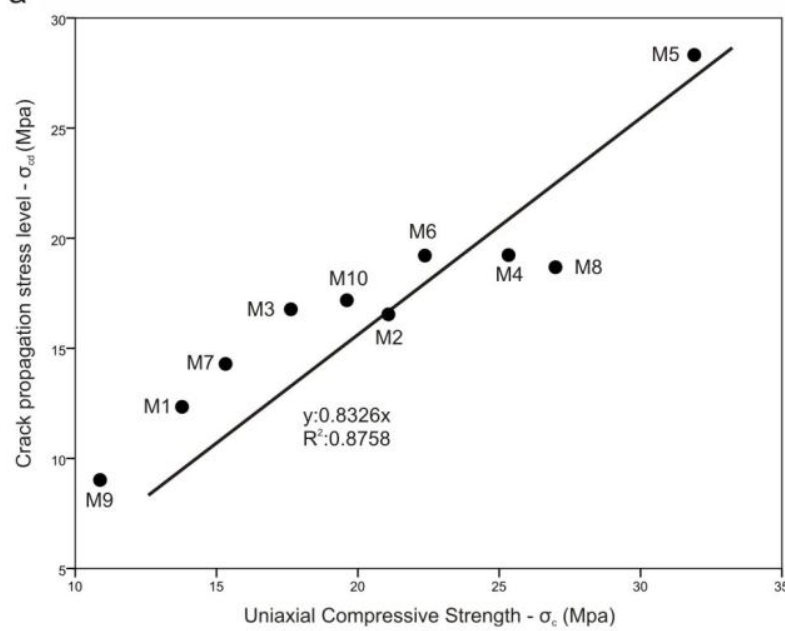

C

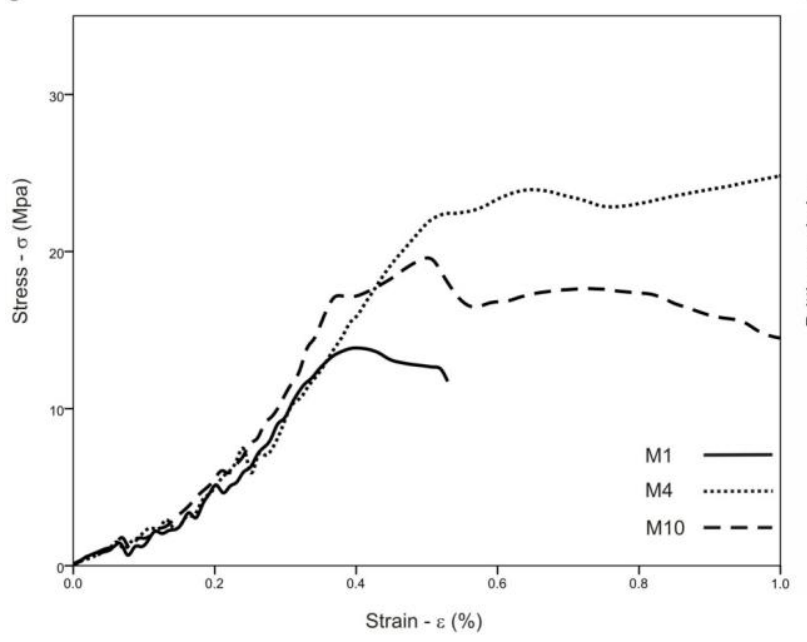

b

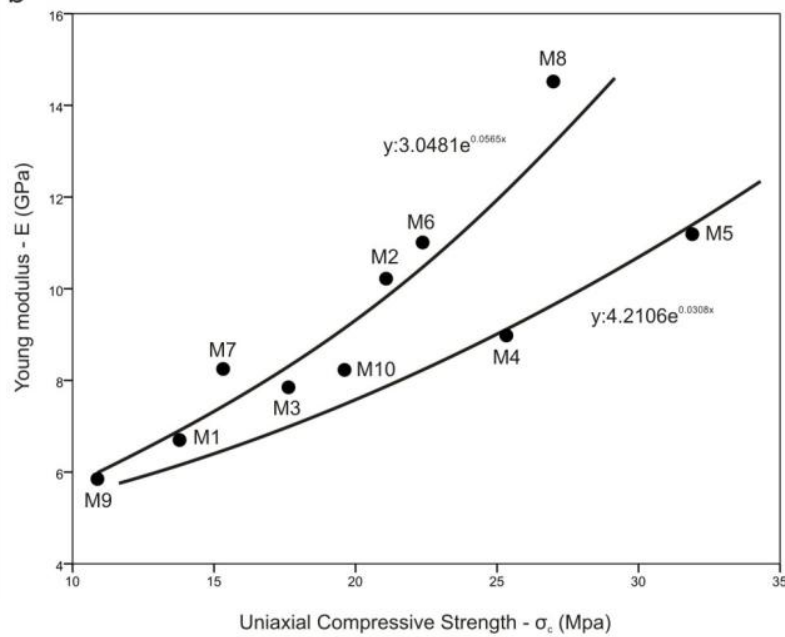

d

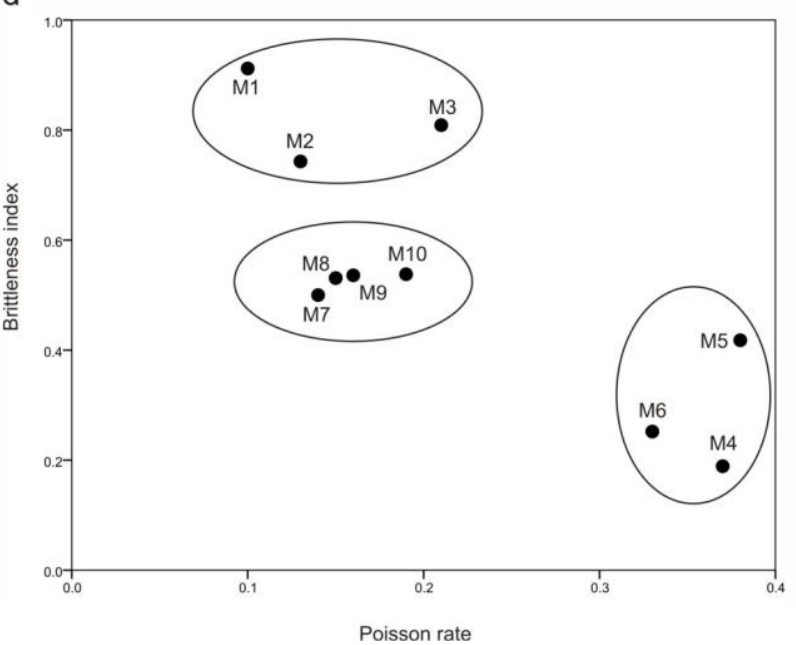

Figure III.5: a: Illustrated plot of the uniaxial compressive strength and crack propagation stress level, which defined the onset of stable fracture growth at the $83 \%$ of the longterm rock strength, which generally agree with $85 \%$ value of the general ISRM (2006) suggestions. $b$ : Plot of uniaxial compressive strength and Young modulus reveals a quite strong increasing trend of the measured rock mechanical features, while only two of the samples (M4 and M5) do not fit to this trend. $c$ : The characteristic stressstain curves from A-2. Sample M1 a strongly rigid nature with low uniaxial compressive strength. M4 represent relatively higher $\sigma_{c}$ and necessary work for the failure of the sample, indicating a strainhardening nature. In contrast, the stress-strain curve of M10 reveals its strongly plastic and inelastic nature. These rock-mechanical features follow each other with increasing depth. d: Plot of measured Poisson rates versus the brittleness indexes with the quite clear separation of the samples derived from distinct fault components: the damage zone (M1-3), the transition zone (M4-6) and the fault core (M710). 
The uniaxial compressive test results $\left(\sigma_{\mathrm{c}}\right)$ can be divided into three different stages according to the depth of the samples (Fig. III.5/c). Down 3291.9 meters in depth the borecores display a quite brittle nature with a very low uniaxial compressive strength $\left(\sigma_{c}\right)$. Down to 3294 meters, the stress-strain curves indicate strongly characteristic rock mechanical properties with extremely wide ductile and locally strain-hardening stages before their failure. The gradual transition from the rigid upper part towards the relatively ductile depth intervals is observable in samples M4, M5 and M6 with a $\sim 10 \mathrm{MPa}$ higher uniaxial compressive strength $\left(\sigma_{\mathrm{c}}\right)$ than the borecores from shallower depth and the appearance of plasticity or even significant strainhardening.

A similar process is observable in the calculated brittleness (B) data of the samples, which is the ratio of the elastic work $\left(\mathrm{W}_{\mathrm{e}}\right)$ and the destruction work $\left(\mathrm{W}_{\mathrm{t}}\right)($ Table III.2/b and Fig. III.5/d). Borecores M1, M2 and M3 have a high B value close to $1(\mathrm{~B}=0.743-0.912)$, while samples below 3294 meter depth can be characterised with lower B values (0.500-0.538). In the case of samples M4, M5 and M6 extremely low B ratios (between 0.189 and 0.418 ) were calculated.

\section{III.5 Discussion}

\section{III.5.1 Interpretation of the microstructural data}

The presence of the fragmented cataclasites indicates that the whole analysed section was affected by a relatively strong deformation (Fig. III.4). In this sense, samples M1, -2 and -3, with their local fault breccia structures can be interpreted as evidence for locally weaker disaggregation compared to the dominant fault rocks. On the other hand, the sporadic fault gouge ribbons are indicative of the most intense deformational stage of the whole rock mass (Hayman, 2006), despite 
these planes always having a subordinate occurrence, even in micro-scale (Fig. III.4/e,f). This arrangement can possibly be explained by the appearance of the strain localization (Hayman, 2006), which concentrates the progressive deformation into thin layers of clay-rich gouges via a positive feedback process, similarly as the deformation bands develop in porous rocks (Aydin, 2000, Fossen et al., 2007).

During the statistical examination of the Furta tectonites, their PIA data were plotted on the graph D1-D2 discriminant functions and illustrated together with the reference data in Fig. III.6. As shown, most of the analysed samples are in the cataclasite category, in agreement with the microstructural observations. During the petrographic interpretation three samples displayed mixed fault breccia - cataclasite structures (M1, 2 and 3) and according to the discriminant analysis, two of them (M1 and M2) reflect a dominantly fault breccia-like clast geometry. In contrast, sample M3 was statistically classified as a cataclasite.

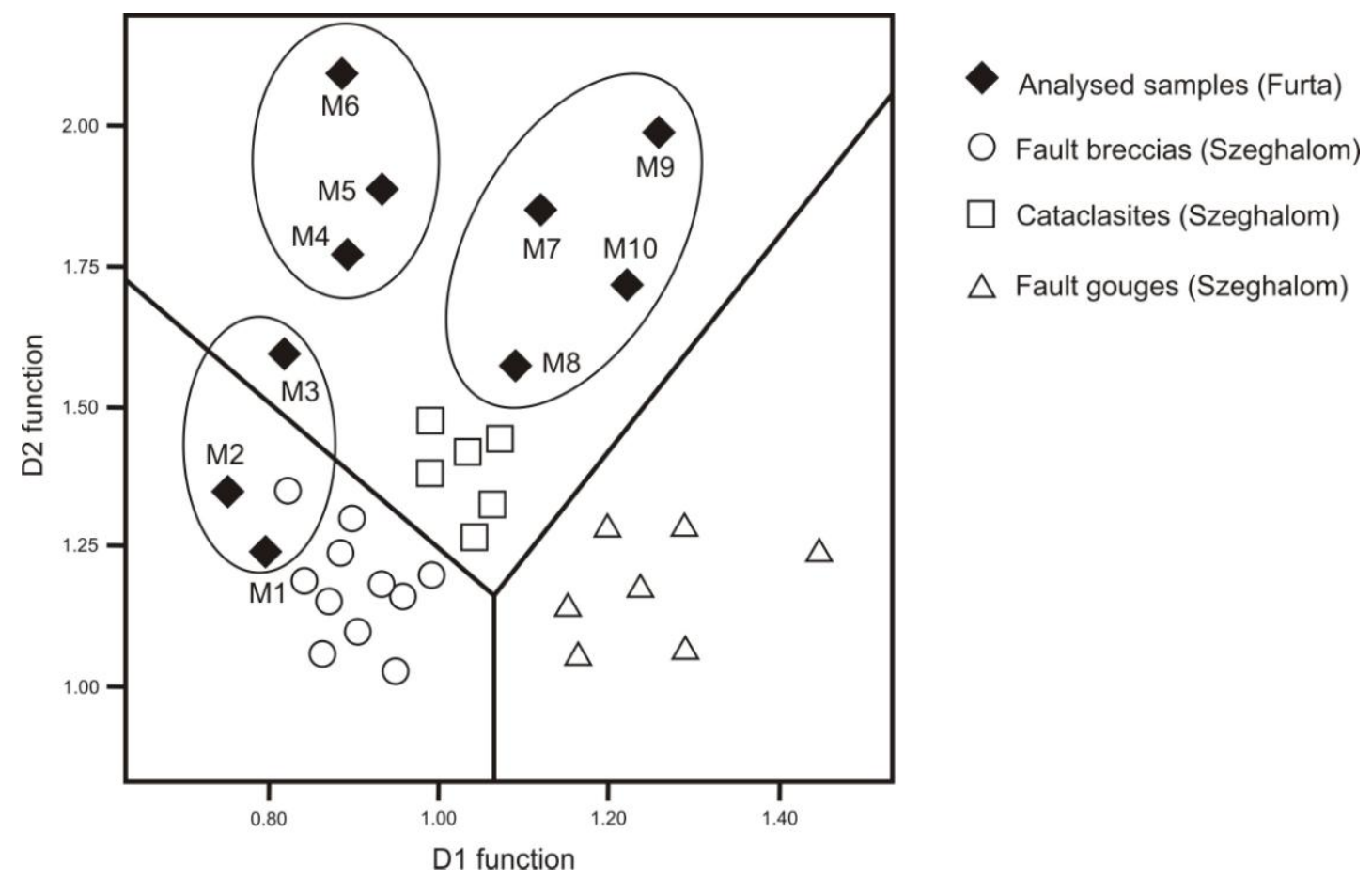

Figure III.6: Illustration of measured fault rock samples from well A-2 based on their calculated D1 - D2 values (detailed in Chapter II.) with characteristic values for each fault component. The reference data of the classification derived from the adjacent Szeghalom Dome are also displayed. 
It is notable that none of the samples fall into the fault gouge category. This outcome possibly relates to their limited appearance and to the previously mentioned very low clast/matrix ratio compared to the adjacent cataclasites. As a consequence, this inevitably leads to the statistical underrepresentation of these domains, even in the most fault gouge dominated samples (e.g. M8 or M10).

In the light of these microstructural inferences and the possible arrangement of the fault rocks, the weaker disaggregated breccias presumably mark the fragmented damage zone component of the fault based on the interpretation of Caine et al. (1996) or Woodcock et al. (2007). In contrast, the cataclasites often cross-cut by gouge surfaces must relate to the fault core, which is the scene of the most considerable displacements (Storti et al., 2007).

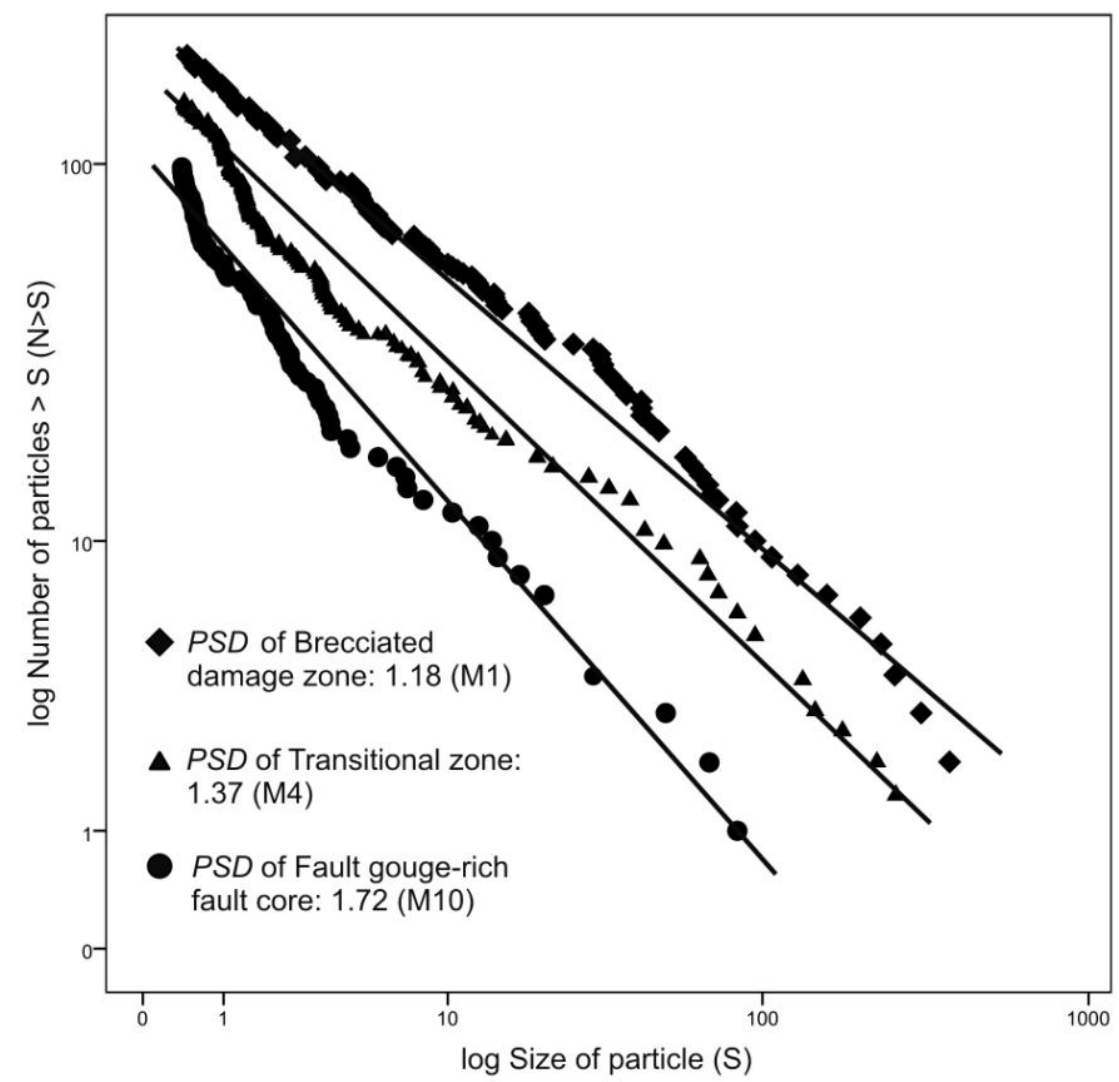

Figure III.7: Characteristic grain size distributions from the three main petrographic zones. These domains reflect higher PSD values with the stronger observed deformation. The coarse grained 
brecciated samples have relatively lower PSD dimensions $(<1.3)$, while, following the transitional values of the cataclasites, samples from the fault gouge-rich zones own the highest PSD dimensions (> 1.6). This latter group can be characterised with increasing comminution and particle size reduction with intensive gouge formation and strain localization.

The representative grain size distribution diagrams from the three main petrographic zones clearly illustrate the increasing PSD values with the observed increasing deformation (Fig. III.7): this process is visible in the decreasing amount of relatively larger particles (i.e. over the $2 \mathrm{~mm}$ limit) in agreement with the observations of Blenkinsop (1991) or Keulen et al. (2007). Consequently, relatively lower PSD dimensions of the breccia dominated samples $(<1.3)$ also indicate that this part of the fault zone can be defined as the damage zone, according to the results of Storti et al. (2003). In contrast, the most deformed gouge-rich samples exceed the theoretical 1.6 PSD value of the gouge formation as it was described by Sammis et al. (1987) or Keulen et al. (2007). According to their evaluations on both naturally and experimentally deformed fault rocks the onset of fault gouge formation is always coupled with the process of shear localization and so, the further particle comminution.

\section{III.5.2 Rock mechanical properties of the fault rocks}

The complex structure of the fault zone in well A-2 is also visible in light of the uniaxial compressive test results. The petrographically defined fault breccia nature of M1 and M2 samples can explain their low uniaxial compressive strength and brittle behaviour (Table III.2/b and Fig. III.5/a). Moreover this tendency possibly continues in the sample M3, despite that it was characterised as cataclasite. Their quite rigid nature possibly relates to the dominantly stick-slip style frictional sliding as a typical feature of the coarse grained, "immature" fault rocks (Storti et al., 2007). 
The stress-strain curves of samples M4, M5 and M6 (Fig. III.5/c) strongly deviate from this trend with their strongly inelastic nature and higher uniaxial compressive strength (Table III.2/b and Fig. III.5/a). This phenomenon presumably relates to the formation of the clay-rich fault gouge ribbons in this depth interval, which tend to accumulate the displacement through a stable sliding style motion coupled with strain localization in these zones, as is characteristic of the "mature" fault rocks (Storti et al., 2007). Additionally,, the remained cohesiveness may be responsible for the observed strain hardening processes in these samples, as inferred by the relatively high destruction work $\left(\mathrm{W}_{\mathrm{t}}\right)$ required for failure during testings.

Samples M7-10 display again an extremely strong ductile and inelastic nature, without any observable trends in rock mechanical parameters with increasing depth (Table III.2/b and Fig. III.5/a). The extremely wide plastic stage on the stress-strain curves (Fig. III.5/c) is a reflection of the fault gouge appearance and strain localization, even in a more dominant form than in the previous samples. In addition, the lower destruction work $\left(\mathrm{W}_{\mathrm{t}}\right)$ values compared to $\mathrm{M} 4$, M5 and M6, imply that the strain-hardening is a less important process at these depth intervals. These data tend to emphasize that, though gouge surfaces microstructurally have only a secondary relevance, their spatial density presumably control the rock mechanical properties of the fault rocks, which manifest in the formation of strong plasticity and weak elasticity in the most mature fault rock samples.

The plot of the Poisson ratio versus the calculated brittleness values (B) also indicate the quite clear separation of the petrographically defined units based on their rock mechanical features (Fig. III.5/d). On the other hand, this strong correlation between uniaxial test results points out the validity of the microstructural classification as well. 
III.5.3 Architecture of the A-2 fault zone

According to the integrated petrographical and rock mechanical investigations, three characteristic zones can be separated along the analyzed section of well A-2 (Fig. III.8):

- Brecciated damage zone (M1-3)

- Transition zone (M4-6)

- Fault gouge-rich fault core zone (M7-10)

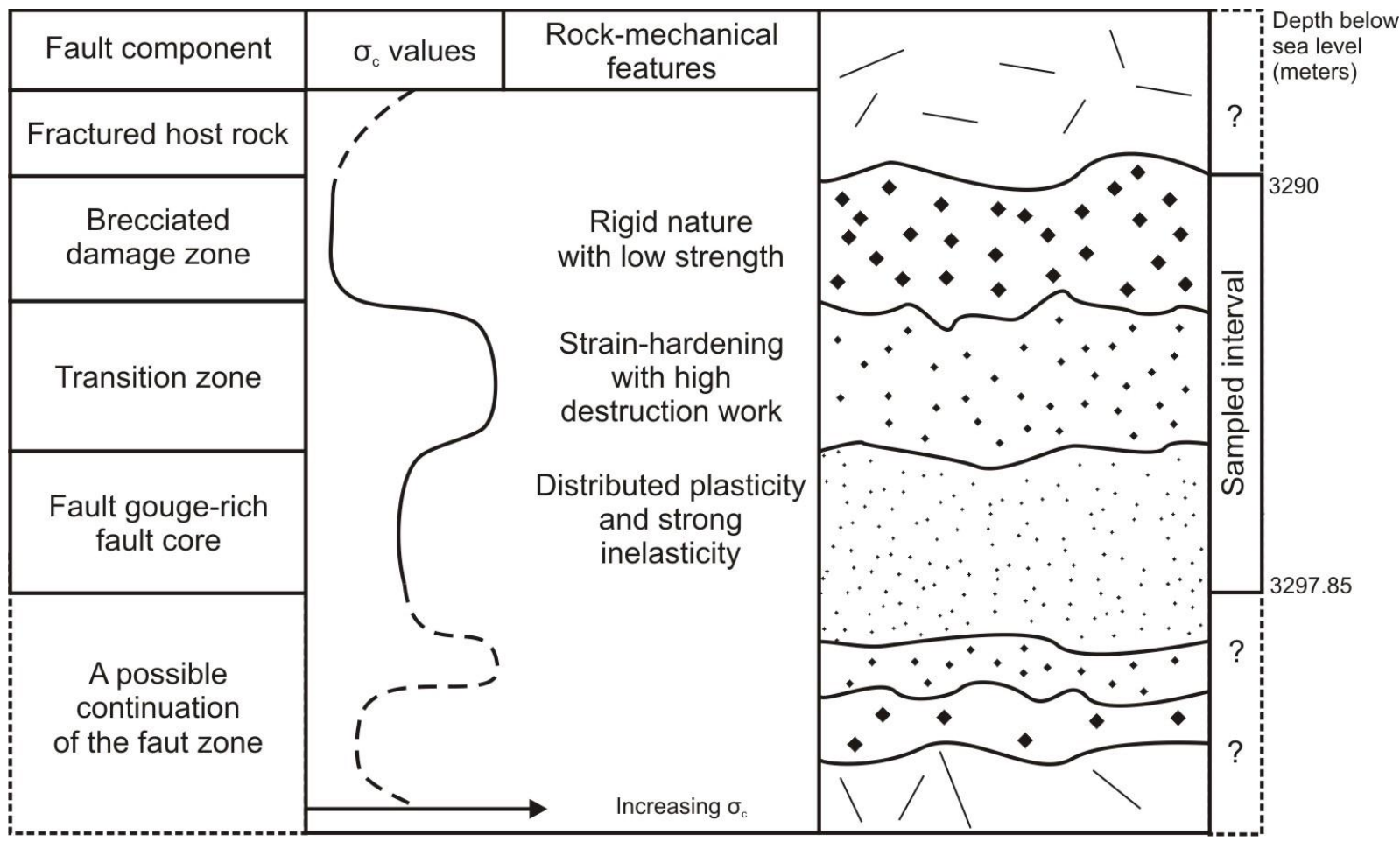

Figure III.8: Schematic composition of the fault zone according to the integrated results of the petrographic and rock-mechanical investigations. For each fault components, their most characteristic features are displayed with the $\sigma_{c}$ data. Increasing $\sigma_{c}$ data towards the undeformed wall rock is presumed due to their less deformed nature. Literature data on the architecture of brittle fault zones suggest the downward continuation of the deformed horizons. Thicknesses of the fault units are not to scale. 
The uppermost zone - which was described as the damage zone of the fault - can be characterised by an extremely brittle nature and low uniaxial compressive strength, coupled with a dominantly coarse fault breccia composition. The microstructural characteristics of the increasing deformation in samples of M4-6, coupled with higher uniaxial compressive strength, strainhardening nature and low brittleness indicate the semi-brittle feature of the suspected border between the weakly fragmented damage zone and strongly ground fault core. Moreover, these attributes suggest this transitional interval is the mechanically strongest part of the fault zone. From the sample M7 downwards, gouge-rich cataclasites mark the core zone of the fault, with their widespread plastic nature and locally pseudo-ductile microstructure. As a consequence, this lowermost zone is presumably an indicator of main slip zones, where most of the displacement accumulated. Generally, the strain localization tends to be strongly linked with the existence of fault gouge ribbons in crystalline rocks (Fig. III.4/e,f), as implied by the results of Evans et al. (1997) and Caine et al. (2010).

The structure of the fault zone further down in depth intervals without borecores - regarding its width and distribution - can only be estimated with a limited reliability, due to the low number of the available samples. However, based on the theoretical fault zone architecture defined by earlier works (Caine et al., 1996, Evans et al., 1997., Storti et al., 2003), the deformed interval have to continue downward toward the undeformed footwall with a symmetric geometry,and a fault zone with $\sim 15$ meter of overall vertical thickness is possible (Fig.III.8.). This fault width can be compared with the observed major basement shear zones in the adjacent Szeghalom (M. Tóth, 2008) and - similarly to those - can be interpreted as a main structural element of MFD (M. Tóth and Zachar, 2006).

The analyzed fault zones in the nearby Szeghalom basement high include distributed damage zones and play a crucial role in the hydrodynamics of the crystalline mass, especially in fluid migration. According to the unpublished industrial data from the Szeghalom reservoir, economic amounts of hydrocarbons were produced from these strongly brecciated intervals and the 
adjacent fractured wall-rock. This observation indicates that a shear zone with rather similar internal structure and geometry of the A-2 well could also be associated with significant porosity and permeability enhancement. Although the fault zone of A-2 is quite far from the main petroleum accumulation in the MFD reservoir (Fig. III.2.), its shear zone can serve as an essential conduit zone of the local hydrocarbon system. On the basis of the most likely scenario (M. Tóth, 2008), hydrocarbons could migrate from the adjacent sedimentary sub-basins into the fracture network of the metamorphic high through the intensely brecciated damage zones of these wide fault zones.

It is known from the Furta field that the 12 productive wells produce at least 7 hydrocarbon fluids that are all different chemically (unpublished report) and these observations indicate that the fractured hard rock reservoir is highly compartmentalized hydrodynamically. From this point of view, the thicknesses of the damage zone and the fault core along the migration pathways are of key importance. The weakly disaggregated damage zone presumably tends to form a connected fracture network with relatively elevated permeability compared both to the undeformed wall rock and the fault core. On the other hand, due to its clay-rich, ductile and thus impermeable behaviour, the core could contribute to the hydrodynamically compartmentalized behaviour of the whole fractured mass (Caine et al., 1996, Caine et al., 2010, Matonti et al., 2012).

\section{III.6 Conclusion}

The well A-2, in the Mezősas-Furta Dome (MFD) provided a large number of borecores with different degrees of deformation. On the basis of an integrated investigation, the petrologically defined fault units have remarkably different rock mechanical behaviours. We suggest that brecciated damage zone may have the best reservoir characteristics, due to their weakly disaggregated structure coupled with quite rigid rheological features. In contrast, the transition zone and fault core with their plastic or strain-hardening nature presumably form barriers for the fluid flow, which can compartmentalise the local hydraulic system. 
Chapter IV.: A fault-controlled fractured metamorphic reservoir in the Pannonian Basin, SE

\section{Hungary}

Manuscript submitted to the Geologica Croatica

\section{Authors}

László Molnár

Department of Mineralogy, Geochemistry and Petrology, University of Szeged, Hungary

Tivadar M. Tóth

Department of Mineralogy, Geochemistry and Petrology, University of Szeged, Hungary

Félix Schubert

Department of Mineralogy, Geochemistry and Petrology, University of Szeged, Hungary 


\title{
A fault-controlled fractured metamorphic reservoir in the Pannonian Basin, SE Hungary
}

\begin{abstract}
The basement of the Pannonian Basin contains several fractured metamorphic hydrocarbon reservoirs that typically form structural highs between the Neogene sedimentary sub-basins. One of the largest reservoirs, the Szeghalom Dome, is located on the northern margin of the Békés Basin and is mainly composed of Variscan gneisses and amphibolites with different metamorphic evolutions. These petrologically incompatible blocks were juxtaposed by post-metamorphic tectonic activity that was accompanied by the formation of brittle fault zones with elevated transmissibilities.
\end{abstract}

The aim of this study was to define the spatial arrangement of these fault zones and their internal architecture by integrated evaluations of borecore and well-log data from a group of wells in the central part of the field. Spatial correlations between the reconstructed 1D lithologic columns revealed the main structural elements of the Szeghalom Dome. The low-angle $\left(<15^{\circ}\right)$ thrust faults most likely developed due to north-northwest vergent Cretaceous nappe tectonics, which was probably responsible for the juxtaposition of the different metamorphic blocks. A complex system of normal faults throughout the basement high provides evidence of intense Miocene extensional tectonic activity. This phase of the geodynamical evolution of the basin is believed to be responsible for the horst-graben structure of the Szeghalom Dome.

The integration of the structural results with datasets of the paleo-fluid evolution, recent production and fracture network geometry indicates the importance of these fault zones in both the migration of hydrocarbons from the adjacent sub-basins to the overlying sediments and the development of significant storage capacity within the strongly fractured rock masses (mainly the amphibolite bodies). These observations of fluid flow also emphasized the impact of strong permeability anisotropy of the faults throughout the fractured reservoir. 
Keywords: Fractured reservoir, Variscan basement, Fault zones, Well-log interpretation, Fault rock analysis

\section{IV.1 Introduction}

Brittle fault zones have a key role in the hydrodynamics of fractured reservoirs (Nelson, 2001). They can behave as barriers, conduits or as a combination (Caine et al., 1996), so understanding their internal structure is crucial. Previous studies (Caine et al., 1996; Evans et al., 1997) on the make-up of fault zones defined two main structural elements: 1) the weakly disaggregated, densely fractured "damage zone", which is generally associated with higher conductivity and permeability relative to the undeformed protolith; and 2) the strongly deformed and fragmented fault core, where the pre-existing rock fabrics have been destroyed by the development of the fault and have been replaced by fault rocks.

Several studies have revealed that the formation of the fault core is often coupled with a significant decrease in permeability (Evans et al., 1997; Wibberly and Shimamoto, 2003, Storti et al., 2007), which is mainly a result of cataclasis, clay smearing or clay gouge formation and cementation (Moeller-Pedersen and Koestler, 1997, Manzocchi et al., 2010). The geometry of the juxtaposed lithologies and their relative transmissibility are also important factors in the conduit/barrier behavior of fault zones (Allan, 1989). The hydraulic character of the deformed zones is further complicated by their strong permeability anisotropy (Evans et al., 1997); the highest permeability evolves parallel to the fault plane and the slip vector, while the hydraulic conductivity is one to four order of magnitudes lower parallel to fault plane and perpendicular to the slip vector or perpendicular to the fault plane and the slip vector. This can result in many types of fault behavior based on the proportion of distinct structural elements (localized conduits, localized 
barriers, distributed conduits, combined conduits-barriers) and depending on the widths of the damage zone and the fault core with respect to the total width of the fault zone (Caine et al., 1996).

The large-scale spatial interpretation of fault zones in hydrodynamic systems can be problematic, especially with a lack of borecores, because the main structural elements are often below the limit of seismic resolution (Ben-Zion and Sammis, 2003). This phenomenon increases the value of data available from borecores and well-logs and suggests the importance of their integration and calibration.

This study focuses on the Pannonian Basin (PB), which is part of the Alpine-CarpathianDinaric orogenic belt. Due to its complex Mesozoic-Neogene evolution (e.g., Tari et al., 1992, Csontos and Nagymarosy, 1998), the PB consists of deep sub-basins that are separated by metamorphic basement highs (e.g., Tari et al., 1999; M. Tóth et al., 2009). In many cases, these blocks act as fractured water and hydrocarbon (HC) reservoirs in which the brittle fault zones play important roles in fluid storage and migration. One of the best known basement highs is the Szeghalom Dome $(\mathrm{SzD})$, which is also one of the largest fractured basement HC reservoirs in the PB (Nelson, 2001). Only a small portion of the accumulated hydrocarbons have been produced because of the complex structural and lithologic architecture of SzD. In this study, we attempt to clarify the post-metamorphic evolution of the study area and to correlate the paleo-fluid evolution with the recent hydraulic features of the $\mathrm{SzD}$ to determine the role of fault zones in the reservoir.

\section{IV.2 Geological setting}

Due to its complex multistage tectonic history, the Pannonian Basin is a complicated mosaic of structural blocks with different geologic evolutions. The crystalline basement of the PB is mainly composed of Variscan metamorphic rocks with significantly different pressure-temperature-time histories (Szederkényi et al., 1991). The SzD is one of the best known units and has a heterogeneous 


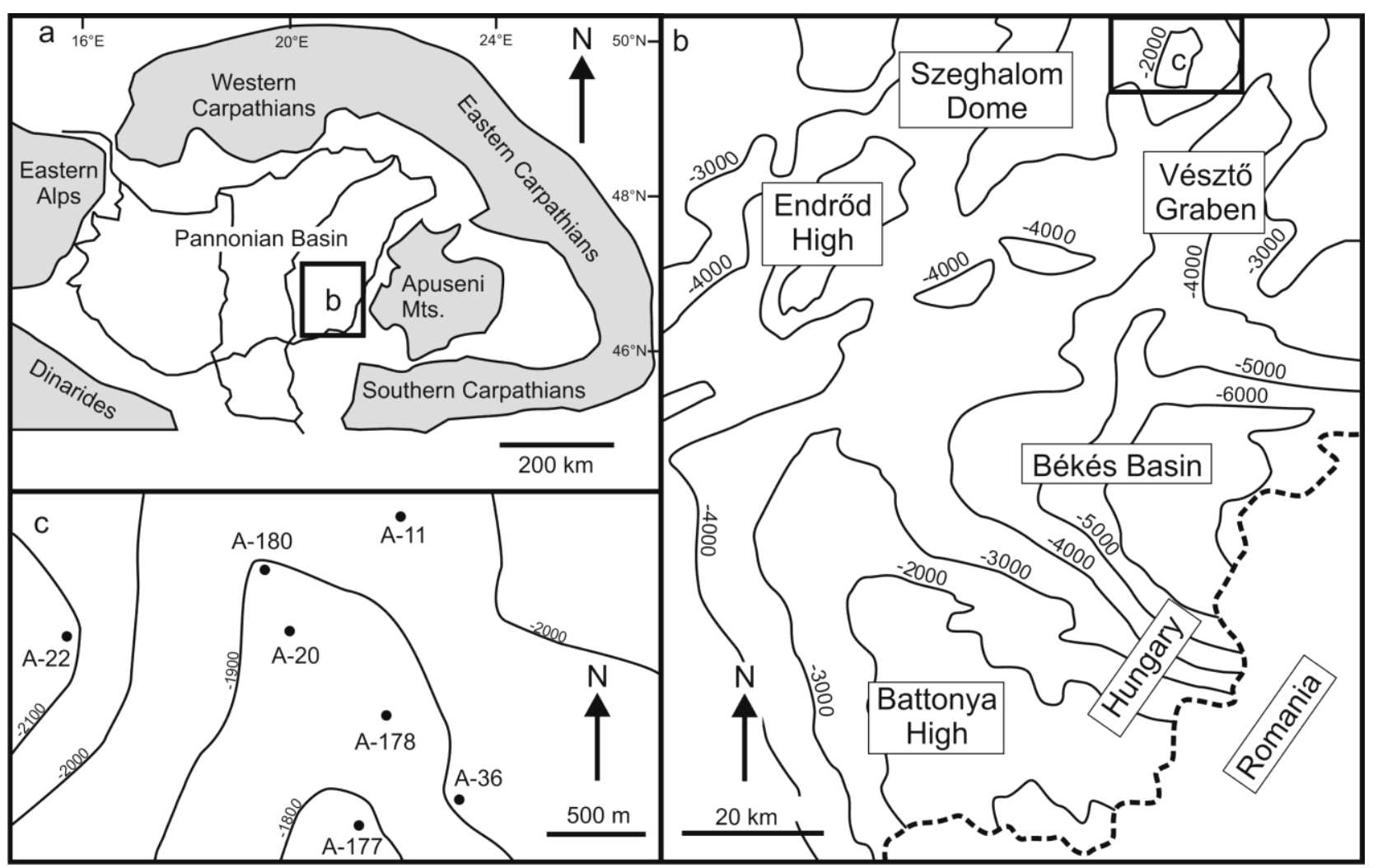

Figure IV.1: a: Location of the Szeghalom Dome in the Pannonian Basin and its geological environment.

b: Szeghalom Dome in the eastern part of the Pannonian Basin with the adjacent sub-basins and elevated basement highs. c: Locations of the sampled wells in the central part of the SzD. The contour map indicates the depth to the basement in meters.

The northern part of the SzD and the neighboring areas are mainly composed of orthogneiss that is derived from the medium-grade metamorphism of an igneous intrusion. In some borecores, undeformed microgranite dikes have no textural indications of metamorphism. These lithologies are jointly called the OG group. In the central and southern parts of the $\mathrm{SzD}$, two other types of gneisses are dominant. The SG group is composed of high metamorphic grade sillimanite and garnet-bearing biotite gneiss that is often coupled with garnet-bearing amphibolite. In contrast, amphibolite and amphibole-biotite gneiss (AG group) with medium grade metamorphism is common at the uppermost structural level. These metamorphic blocks with distinct evolutions (M. Tóth, 2008) were juxtaposed as a result of post-Variscan structural movement. 
The most significant tectonic event after the Variscan metamorphism was the Eoalpine compressional tectonic phase (Laramian, Austrian phases), which formed complicated nappe systems throughout the basement of the Pannonian Basin. Several studies have demonstrated the existence of nappe tectonics in the PB (Posgay et al., 1995; Tari et al., 1999), which resulted in the widespread formation of subhorizontal, north-northwest-directed thrusts throughout the basement. Later back-arc type extension during the middle Miocene resulted in the formation of metamorphic core complexes coinciding with the exhumation of a series of crystalline domes along low-angle normal faults (Horváth et al., 2006). These structures were further complicated by sinistral strikeslip fault zones with significant horizontal displacements (Albu and Pápa, 1992). During the Badenian, the intense extension formed horst-graben structures along north-south striking normal faults (M. Tóth, 2008).

As a result of the complex post-metamorphic evolution of the SzD, a dense fracture network with significant fluid storage capacity developed (M. Tóth, 2008). Previous analyses of the fracture network (M. Tóth et al., 2004) and fracture-filling mineral assemblages (Juhász et al., 2002) demonstrated the significant difference in rheological behaviors of the amphibolite and gneiss bodies. This difference led to the development of a fracture network that is above the percolation threshold of the amphibolites; in contrast, the fracture network in the gneisses is usually below this limit and contains unconnected fracture systems (M. Tóth et al., 2004). The higher storage capacity of amphibolites compared to the gneisses is also demonstrated by paleo-fluid reconstructions of the SzD (Schubert, 2003; Schubert et al., 2007), which reported hydrocarbon-bearing fluid inclusions exclusively from the amphibolite bodies and the damage zone of the faults.

The wide fault zones that separate blocks of different metamorphic evolutions within the SzD may have a key role in the communication between the crystalline basement and the neighboring sedimentary basins; because the flanks of the $\mathrm{SzD}$ are surrounded by relatively deep sedimentary sub-basins with significant overpressures, the fractured basement can act as a migration pathway from the juxtaposed sediments to the overlying sediments (Vass et al., 2009). 
These brittle fault structures can also link separate amphibolite bodies (M. Tóth, 2008; Vass et al., 2009).

The aim of this study is to reconstruct the structural evolution of the SzD and determine the role of the internal architecture of the fault zones in the local fluid flow regimes. The study area is located north of the highest part of the $\mathrm{SzD}$, where the top of the basement is composed of rocks of the AG group. SG group rocks are located in the deeper parts of the basement and are separated from the AG group rocks by wide brittle fault zones.

\section{IV.3 Samples}

The borecores used for the petrographic analysis are from wells A-11, -20, -22, -180: the depth intervals of the samples are summarized in Table IV.1. The most important well (A-180) is located north of the central, highest part of the SzD and intersects a major fault zone. Core recovery from the fault zone is nearly $100 \%$. The fault zone separates the lithologic units of the AG group in the hanging wall and the SG group in the footwall. The examined section is approximately 20 meters wide and extends from a depth of 1913 meters to 1936 meters; it is primarily composed of brittle fault rocks with different degrees of deformation (Fig. IV.2). Samples of both the undeformed footwall and the hanging wall were analyzed to define their well-log properties.

Figure IV.2: a, b: Coarse fault breccia with gneissic origin $(1 N,+N)($ well A-180). c, d: Crushed, slightly elongated clasts in cataclastic fabric $(1 N,+N)($ well A-180). e, f: Fault gouge clasts composed of crushed mono-crystals $(1 N,+N)$ (well A-180). The scale bars are $500 \mu \mathrm{m}$ long. $\rightarrow$ 

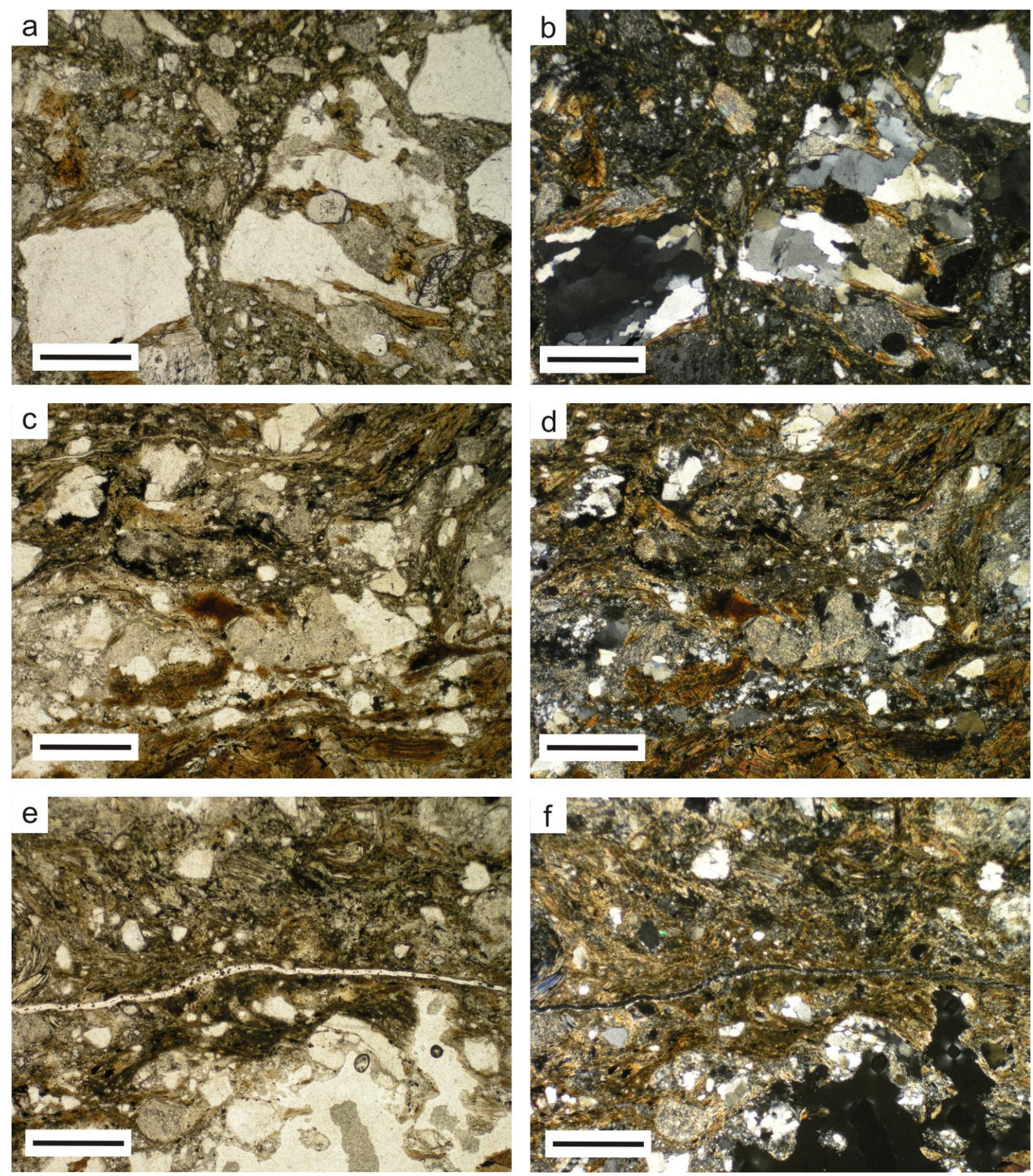

Well-log analysis was applied to the wells A-11, -20, -22, -36, -177, -178 and -180 . The well-log data were provided by the MOL Hungarian Oil and Gas Company. The well-log measurements were recorded every $20 \mathrm{~cm}$ for the following parameters: spontaneous potential (SP), caliper width (Cal), resistivity (Res), density (Den), compensated neutron porosity (CN), acoustic velocity (AC) and natural gamma logs (GR). 


\begin{tabular}{|c|r|}
\hline Well number & Depth intervals of the borecores (meters below sea level) \\
\hline A-11 & $1957-1968$ \\
& $2007-2009$ \\
A-20 & $1901-1903$ \\
& $1976-1979$ \\
A-22 & $2117-2119$ \\
A-180 & $1913-1936$ \\
\hline
\end{tabular}

Table IV.1: The available borecores with their intervals, in meters below sea level.

\section{IV.4 Methods}

The available borecores were analyzed petrographically at both meso- and micro-scales. The tectonites were classified according to their clast geometric parameters as described in the Chapter II.

The well-log data were calibrated on the depth intervals that overlapped with the petrographically analyzed cores. The data set was statistically evaluated using the IBM SPSS 20.0 statistics software. The discriminant function analysis method was used to separate the lithologic groups based on their well-log properties (the forward stepwise method using Wilks' lambda) (Fig. IV.3/a).

Figure IV.3: a: Detailed lithologic composition of the fault zone in well A-180 with the calculated D(1-2) values. The fault gouge-bearing intervals at 1917, 1922 and 1926 meters indicate the locations of the largest displacements. $b$ : Theoretical workflow for the determination of the lithologic architecture in the analyzed wells. Functions $D(3)$ and $D(4)$ are applied only when $D(1-2)$ defines the sample as a tectonite. $c$, d: Representative well-log sections for undeformed $(c)$ and deformed $(d)$ depth intervals, which are verified with the borecore data. $\rightarrow$ 
a

A - 180 well

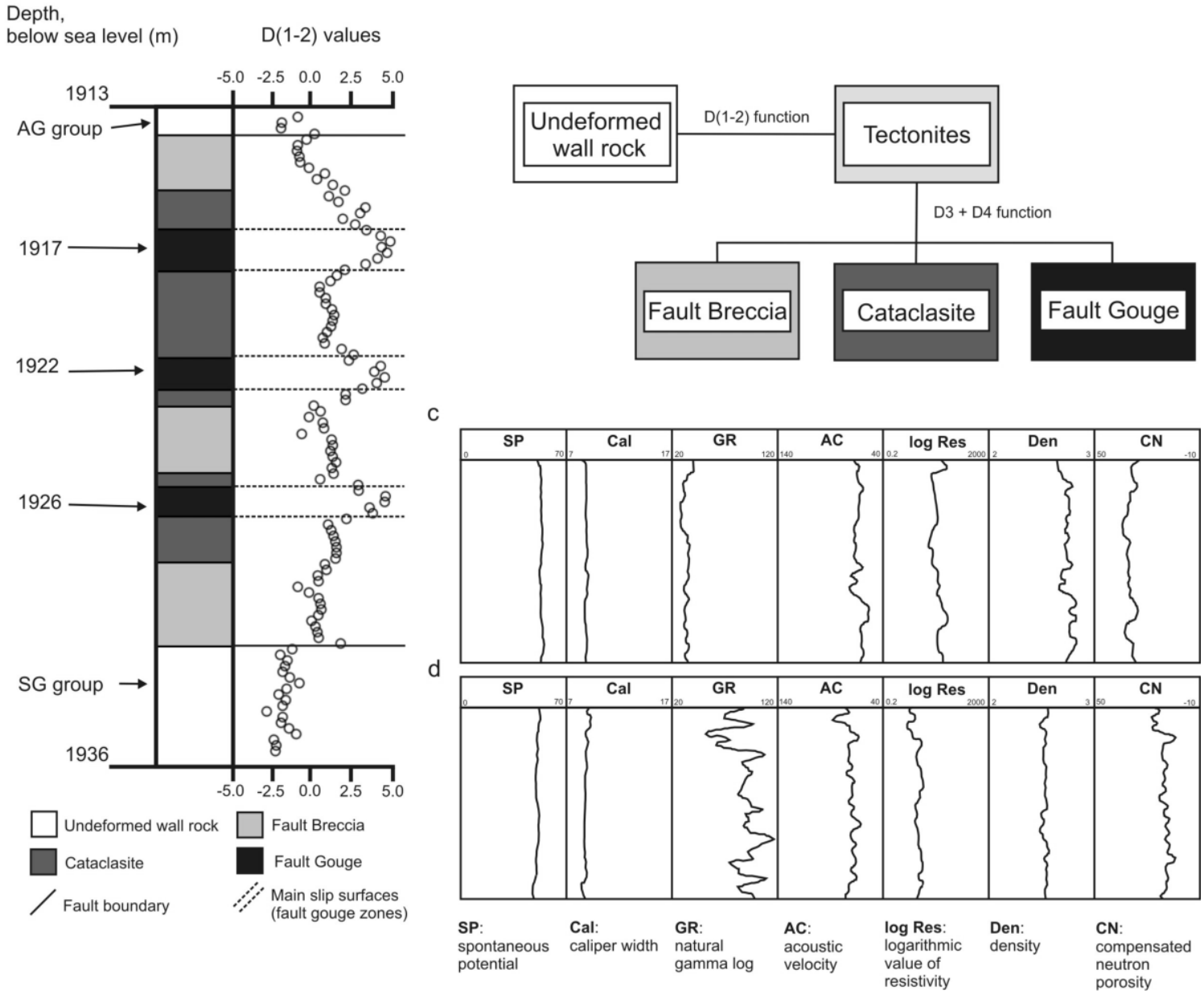

First, a discriminant function was computed to define the difference between the undeformed wall rock (AG and SG together) and the tectonized depth intervals by calculating the proper linear combination of the measured well-log data (Fig. IV.3/b). Discriminant functions were then calculated to define the different types of fault rocks (fault breccia, cataclasite, fault gouge) within the zones that were classified as tectonized in the previous step (Fig. 3/b). Both types of discriminant functions were cross-validated to test the efficiency of the prediction model. The computed functions were then applied on the depth intervals of the analyzed wells where the lithology was unknown. 


\section{IV.5 Results}

\section{IV.5.1 Petrography}

The internal structure of the shear zone in well A-180 reflects the diversity of the petrographic characteristics of the different types of tectonites (fault breccias, cataclasites and fault gouges) (Fig. IV.2). Samples from A-11, -20 and -22 composed of strongly fractured and partly brecciated gneisses from the AG lithologic group. Intact borecore from the SG group was available only from one well (A-11:2007-2009 depth interval) with sillimantie-bearing biote gneissic compostion.

Most of the analyzed samples in A-180 were composed of coarse fault breccia that contained weakly disaggregated structures and clast sizes that were typically greater than $\mathrm{cm}$-scale (Fig. IV.2/a-b). The particles in these samples are only weakly rotated and often fit together along their sharp, angular dilatational edges, reflecting a typical jigsaw texture (Mort and Woodcock, 2006). These weakly disaggregated fault breccia clasts usually have a chaotic structure and lack a preferred orientation. The particles are dominantly composed of rock fragments that are derived from the wall rock and have a recognizable gneiss precursor, while single mineral fragments are subordinate in the fault breccias. A few samples of the breccias have similar internal structures; those with smaller clasts are regarded as micro-breccias, and the coarse fault breccias are often embedded in greenish chlorite or brownish iron-oxide cement. Precipitation of Fe phases is always visible on the margins of the angular clasts.

Several samples show characteristic features of cataclastic deformation that resulted in a decrease in clast size and an increase in the matrix ratio (Fig. IV.2/c-d). A preferred local orientation is formed by the elongation of clasts; the direction is defined by their long axes and is often accompanied by deformed phyllosilicate flakes. These samples have an anastomosing texture that implies semi-brittle deformation. The fragmentation in the cataclasite samples makes the protolith 
of the crushed particles difficult to define because they are often monomineralic (composed mainly of quartz or feldspar). Iron-oxide cement is also often present, in contrast to the missing chlorite cement.

A third type of samples, the incohesive fault gouges, is present in thin deformational bands (Fig. IV.2/e-f). These bands are mainly composed of strongly comminuted mono-crystalline (mainly quartz) particles; only a few survivor rock fragments are observable. The isolated fragments are surrounded by the completely crushed parts of the protolith. The anastomosing fabric of these samples also indicates a semi-brittle style deformation. These fault gouge zones are usually a few $\mathrm{cm}$ wide and presumably define the localized slip zones of the faults, which are probably the locations of the most intensive displacements.

The fault zone in well A-180 is predominantly composed of weakly disaggregated, coarse fault breccias. This intensely fractured host rock presumably forms the damage zone of the fault zone. In contrast, the zones of cataclasite and fault gouge are up to one meter wide and are considered as the fault cores; they are most clear at three distinct depth intervals $(1917,1922$ and 1926 meters below sea level) (Fig. IV.3/a). These surfaces are structurally confined between horizons of coarse fault breccia. As in previous studies (e.g., Evans et al., 1997), the fault cores are typically meters thick; the fault cores imply the localization of strain within the fault zone and mark the locations of most of the displacement.

\section{IV.5.2 Well-log data}

To extend the lithologic data from the borecores to the other intervals of wells, calibration with well-log data was necessary. The proper combination of well-log data was calculated by applying discriminant functions analysis to separate the distinct lithologies (Fig. IV.3/b).

The undeformed host rock (Fig. IV.3/c) and the tectonized samples (Fig. 3/d) were separated using the following discriminant function: 
$D(1-2)=1.1 *$ natural gamma $(G R)-0.5 *$ resistivity $($ Res $)-0.9 *$ density $($ Den $)$

The calculated function successfully discriminated the undeformed host rock and the tectonized intervals without any overlap (Fig IV.4/a). To define the internal structure of the tectonized zones, the lithologically-known fault rocks (fault breccia, cataclasite and fault gouge) were then separated using two discriminant functions:

$$
\text { D3 }=0.7 * \text { compensated neutron porosity }(C N)-0.5 * \text { resistivity }(\text { Res })
$$

$$
D 4=0.6 * \text { density }(\text { Den })-0.9 * \text { natural gamma }(G R)
$$

These two discriminant functions clearly separated the different fault rocks, especially the clay-rich fault gouge samples (Fig. IV.4/b). These functions were then applied to classify the lithologically-unknown depth intervals of wells A-11, -20,-22, -36, -177, -178 and -180 to determine their lithologic and structural compositions.

a

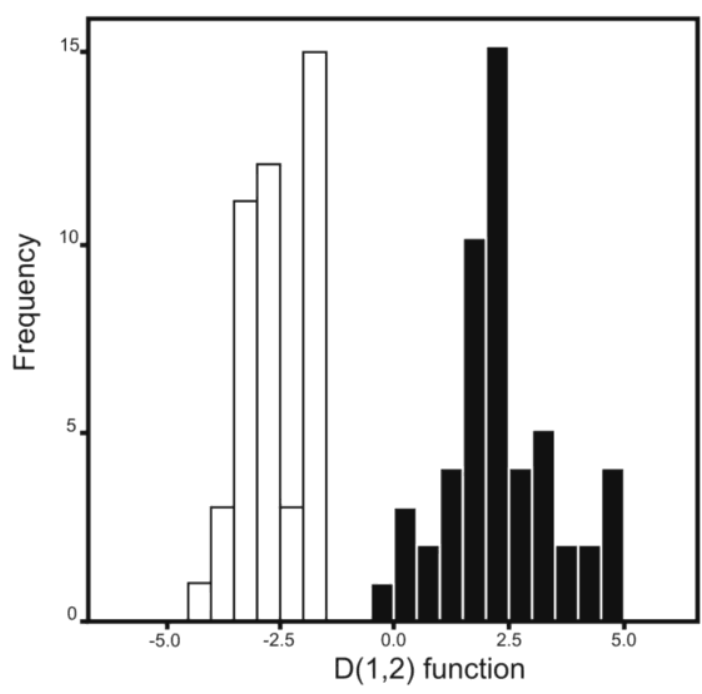

Undeformed wall rock b

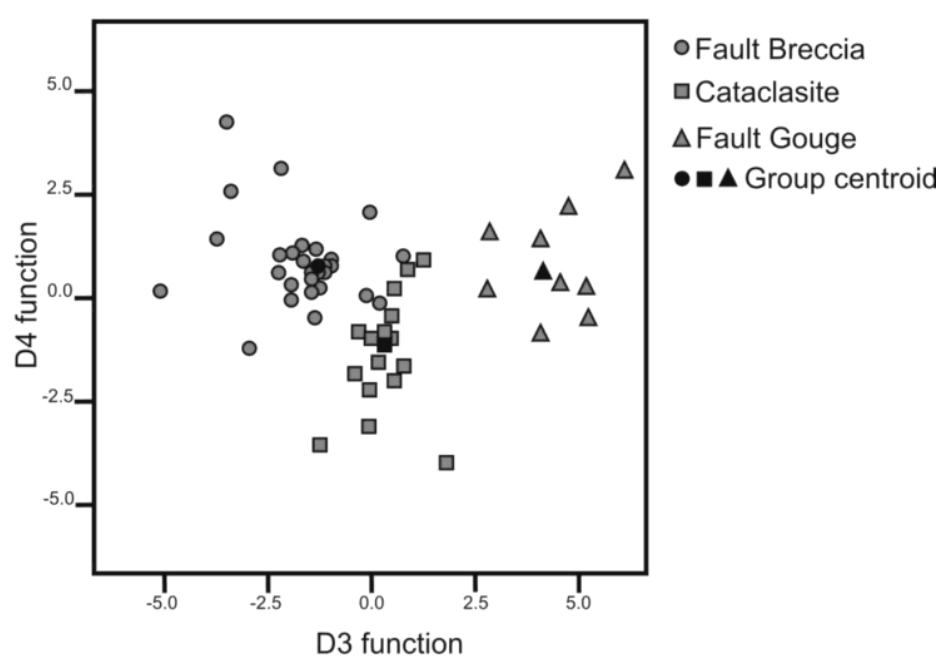


$\leftarrow$ Figure IV.4: a: Separation of the deformed and undeformed depth intervals using the scores of the calculated D (1-2) function. The most important well-log parameters used to discriminate the intervals were the natural gamma, density and resistivity values. $b$ : Discrimination of different fault rock types with the calculated D3 - D4 functions, which are mainly based on the compensated neutron porosity, resistivity, density and natural gamma log values.

\section{IV.6 Spatial extension of petrological and well-log data}

IV.6.1 Well-log properties of the lithologies

The weights of the parameters in discriminant function D (1-2) define the main geophysical differences between the undeformed protolith and the tectonized zones (Fig. IV.4/a). The greatest factor in the difference is the high natural gamma ray values, which implies an elevated amount of clay minerals that is presumably caused by the intensely weathered and altered host rock in the fault zone (Fig. IV.5). The relatively lower electrical resistivity of the tectonites reflects their strongly fractured/fragmented characteristics, which results in stronger fluid infiltration into these zones. The lower densities are probably related to the presence of the higher fracture density in the tectonized zones, which is often coupled with porosity enhancement (Fig. IV.5).

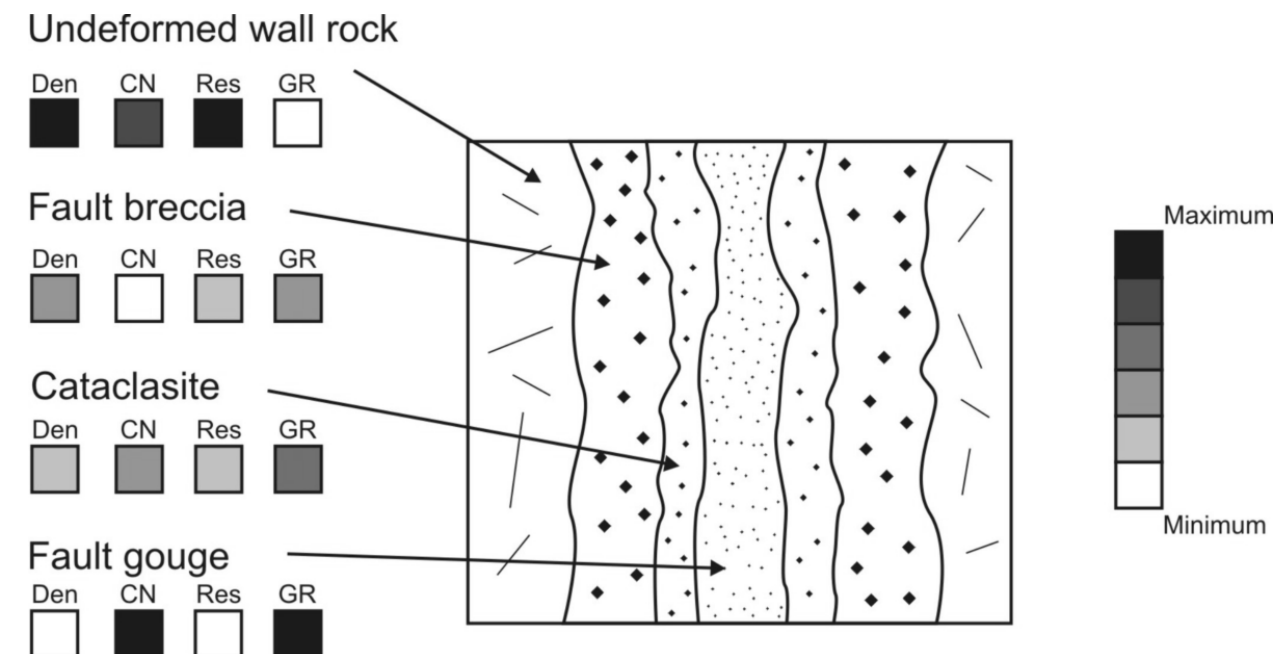


$\leftarrow$ Figure IV.5: Spatial variations of the most important well-log parameters for an idealized fault zone. The darker colors indicate greater parameter values. According to this interpretation, the deformation is often associated with decreasing density and resistivity towards the core zone. The most significant porosity enhancement develops in the weaker fragmented and brecciated zones.

The petrographic and well-log properties of the different tectonite types are strongly heterogeneous in both their petrographic and well-log properties (Fig. IV.4/b), which reflect the internal structure of the fault zones. According to function D3, higher levels of deformation are manifested in increases of the compensated neutron porosity values and further decreases of the electric resistivity. In function D4, higher density and lower gamma-ray values are characteristic. These suggest that the intensely deformed parts of the fault zones (cataclasites and fault gouges) can be characterized by low densities and resistivities and that further elevated natural gamma activity and compensated neutron porosity values mark the fault core, which is consistent with the observations of Hung et al. (2007) and Jeppson et al. (2010). The density and resistivity logs imply intensive fracturing, fragmentation and communition, while the natural gamma and neutron porosity values indicate strong weathering and clay mineral formation with significant porosity reduction (Fig. IV.5). In contrast, the interpreted damage zone with coarse fault breccias has higher density and resistivity values and lower gamma and neutron porosity values (Fig. IV.5). These suggest that the weaker disaggregated zones can maintain a significantly higher porosity than the comminuted fault core.

IV.6.2 Structural interpretation of the analyzed part of the $S z D$

The application of the discriminant functions described above to the well-log data from wells A-11, $-20,-22,-36,-177,-178$, and -180 provided an opportunity to determine the lithologies that 
were present in these wells and to understand the structural evolution of the SzD (Fig. IV.6). Based on the available data, three groups of wells can be distinguished from the seven wells: two triplets (A-180, -11, -20 and A-36, -177, -178) and a group containing one well (A-22).

The most important well was A-180 because the large number of core samples provided useful information about the architecture of the $\mathrm{SzD}$. The fault zone in well A-180 contains strong structural heterogeneities between the depths of 1915 and 1935 meters, where the three main cataclasite and fault gouge-bearing zones are always embedded in coarse fault breccia members (Fig IV.3/a). These comminuted planes - especially the clay-rich gouge zones - can act as the slip zones of the fault zones, and their presence indicates strain localization. An interpretation of the well-log from well A-20, which is the closest well to A-180, indicates that it also contains a distributed fault zone with wide, gouge-bearing fault core between 1990 and 2005 meters (Fig. IV.6) and this implies that the two wide tectonized intervals in the neighboring wells are parts of the same fault zone. Similar gouge-bearing, distributed fault zones with wide damage zones are present in well A-11 at approximately the same depth interval $(\approx 1985-2000 \mathrm{~m})$ as in A-20 (Fig. IV.6). These three occurrences of the interpreted shear zone define a low angle $\left(13^{\circ}\right)$ fault plane that dips to the southeast. Other more weakly fragmented and thinner fault planes are also observed in these wells but do not contain cataclasite gouge-bearing (slip) zones. These data suggest that the fault cores were the locations of the largest displacements and can be considered a major fault zone (Fig. IV.6).

Figure IV.6: The interpreted lithologic compositions of the analyzed wells. The dashed line indicates the observed low-angle fault surfaces. The wells form two triplets, including a northern and a southern block. Along with the lithologic composition, the calculated D(1-2) values are also illustrated along the $1 D$ section of the wells. $\rightarrow$ 
电
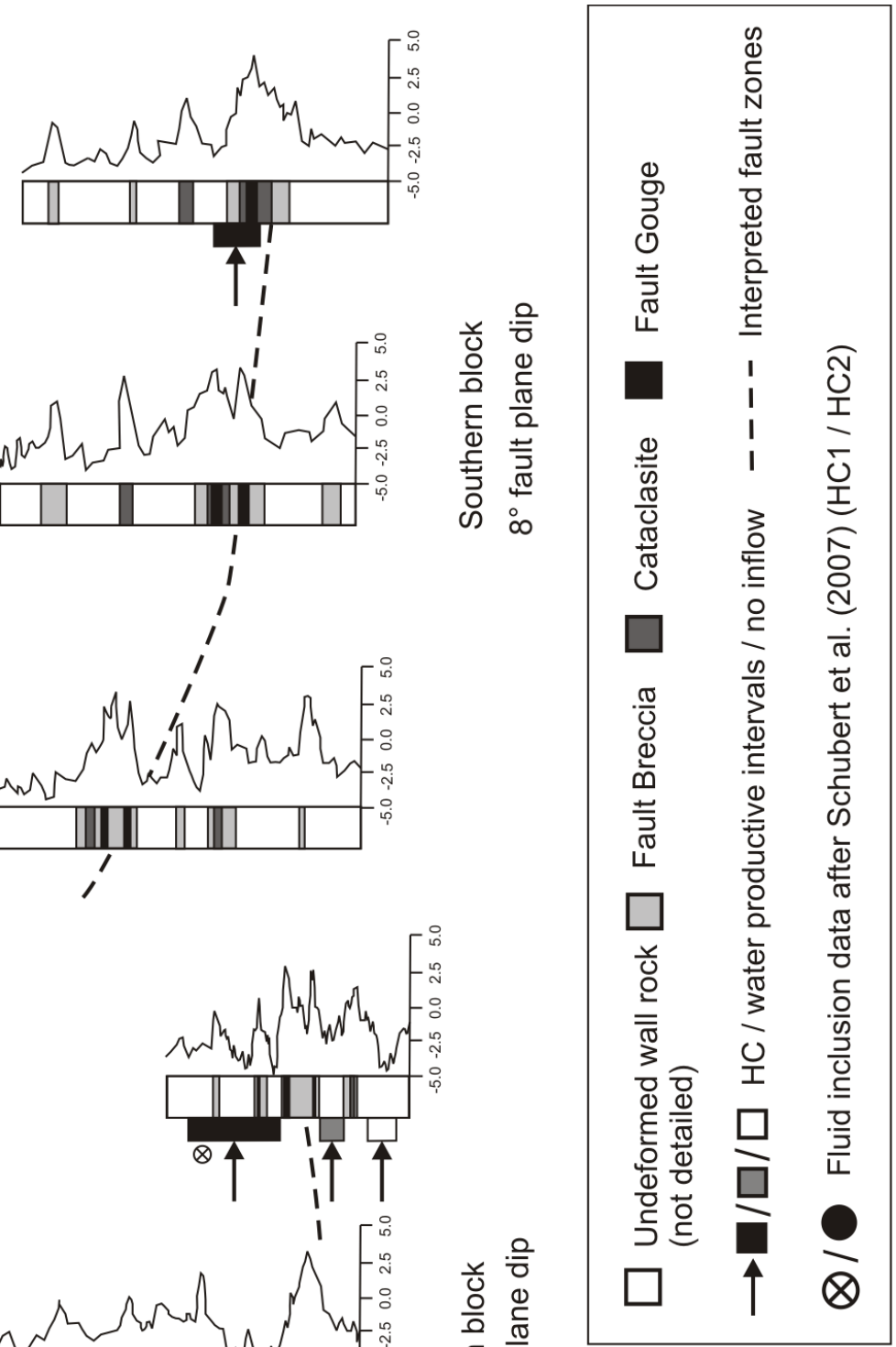

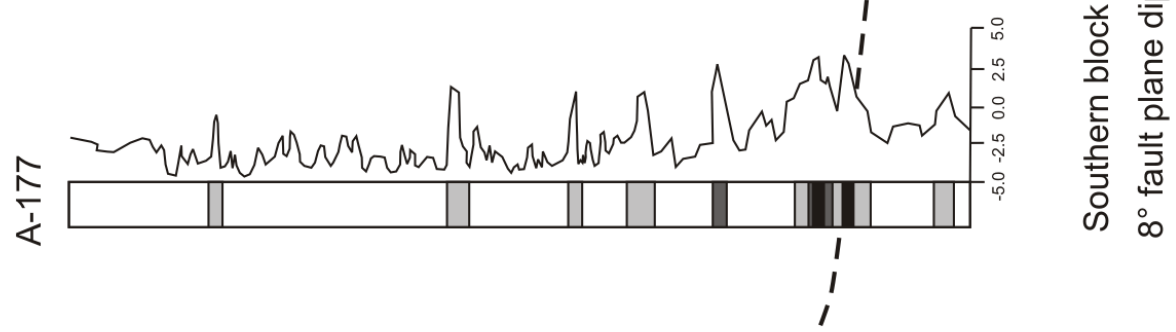

$\stackrel{\infty}{\frac{\infty}{i}}$

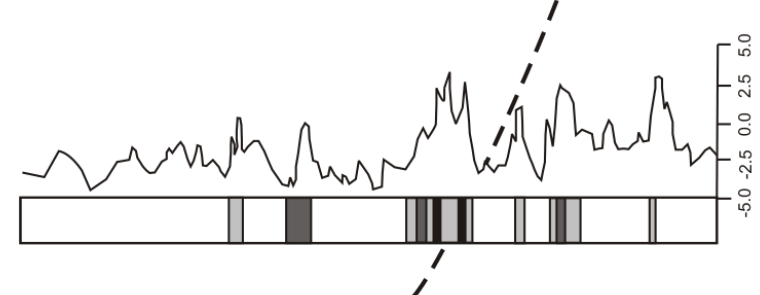

$\frac{5}{4}$

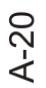

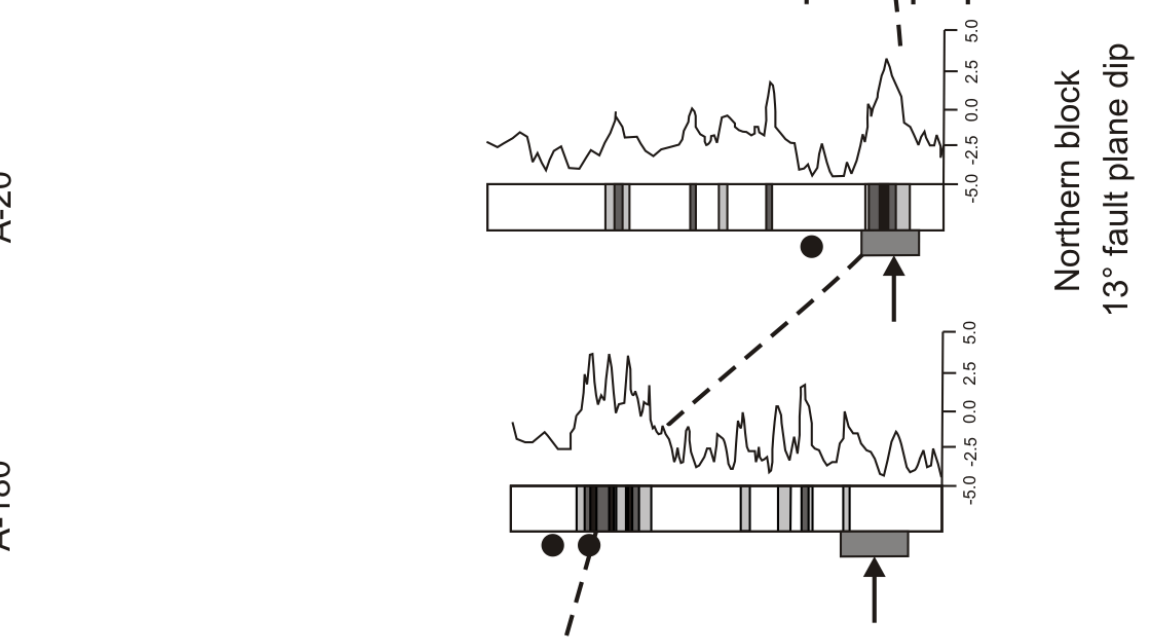

$\frac{\infty}{\frac{1}{1}}$

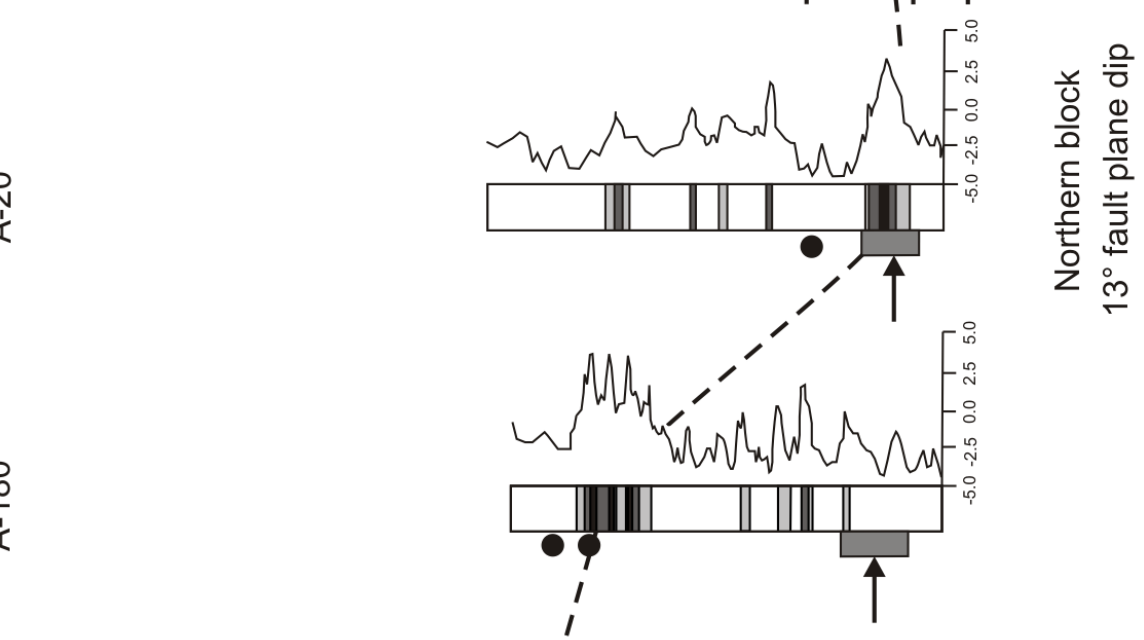

N
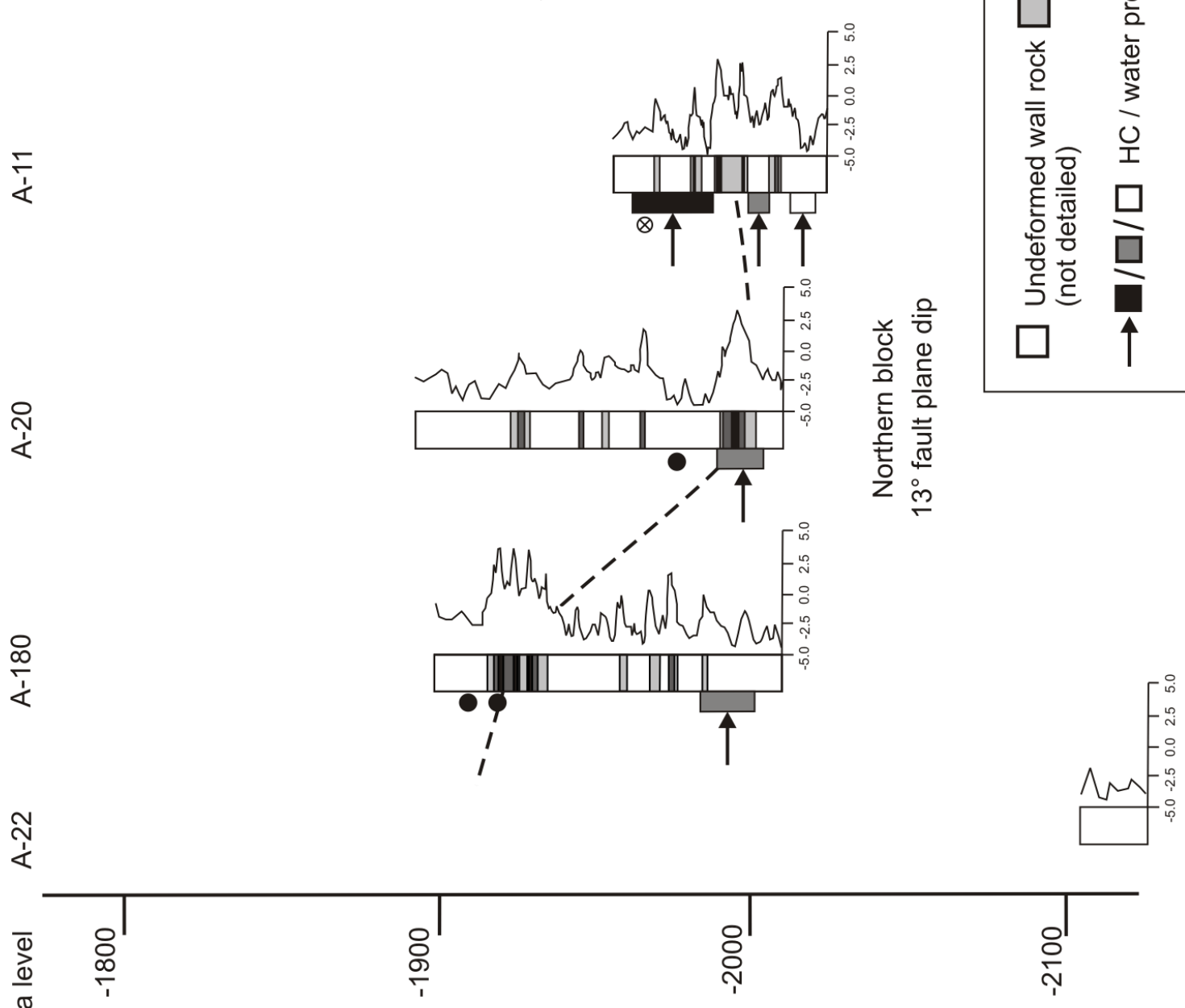

竞亮 
The most important well was A-180 because the large number of core samples provided useful information about the architecture of the $\mathrm{SzD}$. The fault zone in well A-180 contains strong structural heterogeneities between the depths of 1915 and 1935 meters, where the three main cataclasite and fault gouge-bearing zones are always embedded in coarse fault breccia members (Fig IV.3/a). These comminuted planes - especially the clay-rich gouge zones - can act as the slip zones of the fault zones, and their presence indicates strain localization. An interpretation of the well-log from well A-20, which is the closest well to A-180, indicates that it also contains a distributed fault zone with wide, gouge-bearing fault core between $~ 1990$ and 2005 meters (Fig. IV.6) and this implies that the two wide tectonized intervals in the neighboring wells are parts of the same fault zone. Similar gouge-bearing, distributed fault zones with wide damage zones are present in well A-11 at approximately the same depth interval $(\approx 1985-2000 \mathrm{~m})$ as in A-20 (Fig. IV.6). These three occurrences of the interpreted shear zone define a low angle $\left(13^{\circ}\right)$ fault plane that dips to the southeast. Other more weakly fragmented and thinner fault planes are also observed in these wells but do not contain cataclasite gouge-bearing (slip) zones. These data suggest that the fault cores were the locations of the largest displacements and can be considered a major fault zone (Fig. IV.6).

Wide tectonized zones that indicate relatively large displacements are present in well A-178 at depths of $\approx 1925-1945$ meters. Similar zones are also present at similar depths in wells A-177 and A36; however, the interval is slightly thinner interval in A-36 (A-177: $\approx 1955-1970$ m, A-36: $\approx 1960$ 1980) (Fig. IV.6). These depth intervals also include the gouge-bearing slip zones, which imply that these intervals have a similar origin to the shear zone in wells A-11, -20 , and -180 . In this sense, the fault zone in the southern group of wells (A-36, -177, and -178) is the continuation of the zone found in the northern group with a slightly smaller dip angle $\left(8^{\circ}\right)$ but a similar south-southeast dip. Although the small amount of available information only allows a rough estimate of the geometry of the fault planes, and there is a slight difference in the dip angles and directions, the faults in these groups of wells were likely affected by a similar deformational event. 
Based on the interpretation of several analogous examples from the crystalline basement (e.g., Pap, 1990, Tari et al., 1999), these fault zones can be interpreted as a low-angle thrust with a northwest vergence. This explanation is consistent with the reinterpretation of $2 \mathrm{D}$ seismic profiles from the metamorphic basement (M. Tóth et al., 2009). Because these old seismic surveys mainly focused on the overlying clastic sediments, they provided only sporadic reflectors from the crystalline basement. Using sophisticated seismic interpretation techniques, this study (M. Tóth et al., 2009) defined the largest structural elements and characterized most of them as low-angle thrust surfaces.

Earlier studies reported that the formation of these low angle $\left(\approx 5-15^{\circ}\right)$, northwest-vergent thrust sequences throughout the basement of the Pannonian Basin are related to Eoalpine compressional activity during the late Cretaceous nappe formation (Teleki et al., 1994; Tari et al., 1999, Kovács et al., 2000). The AG and SG lithologic groups, with their distinct metamorphic pathways, were juxtaposed by this Eoalpine nappe activity.

The repeated presence of the thrust surfaces and their spatial arrangement indicate postCretaceous tectonic activity between the northern and the southern groups of wells, which cross-cut the initially approximately uniform thrust surface (Figs. IV.6 and IV.7). The dip of the thrust and the depth of the tectonized intervals indicate high angle extension with approximately 150 meters of vertical displacement combined with tilting of the northern hanging wall block (Fig. IV.8). A similar tectonic style is indicated in well A-22, which reached the basement surface approximately 200 meters deeper than in the adjacent wells and penetrated the only $\sim 20$ meters of basement rocks of the AG group (Fig. IV.6). Because the AG group is in the highest structural locations in the SzD (M. Tóth, 2008) (Fig. IV.7) and always forms the top of the basement, the significant vertical difference between wells A-22 and A-180 is probably also the result of post-Cretaceous motion (Fig. IV.8). 


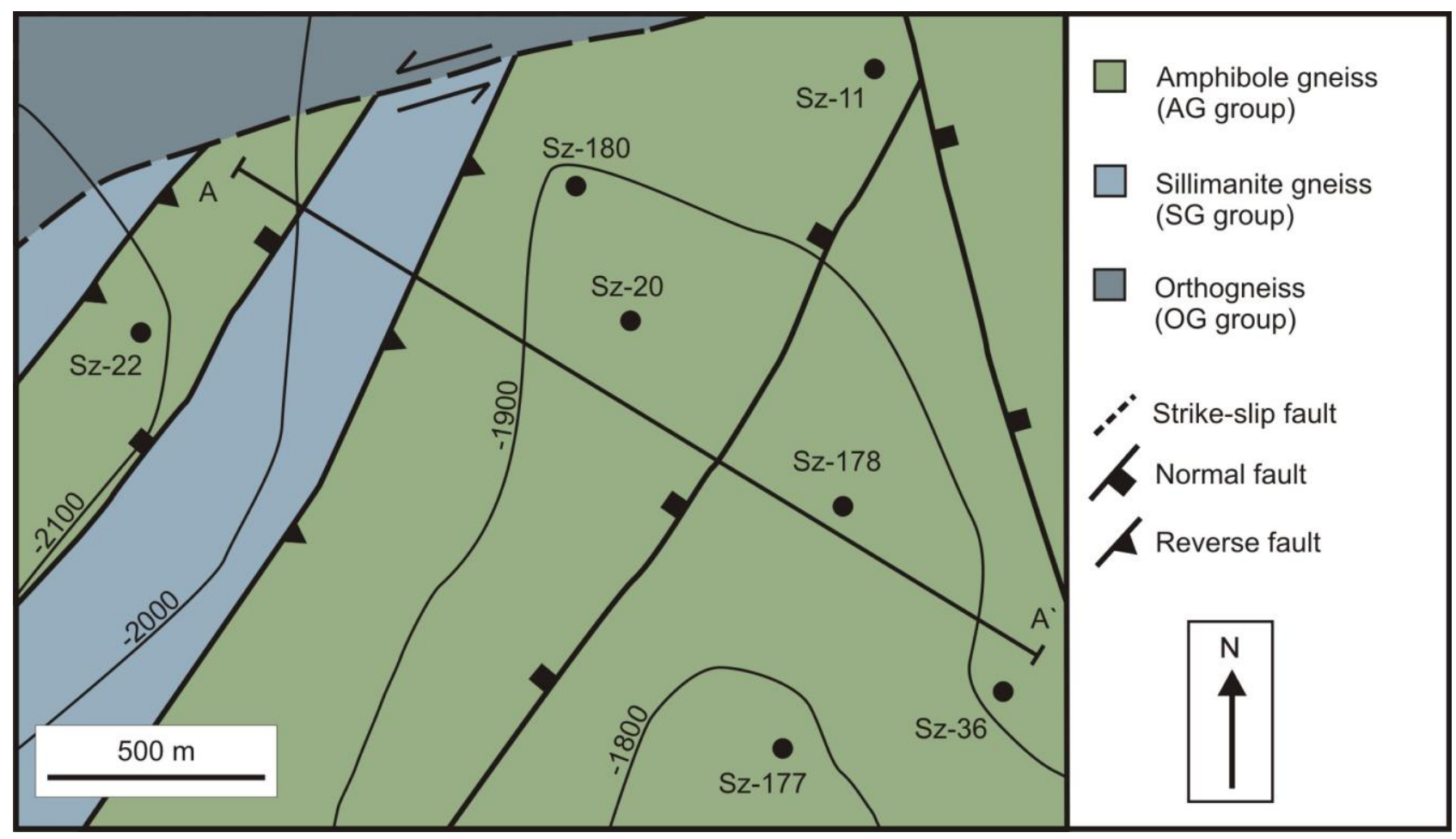

Figure IV.7: Basement map of the Szeghalom High with the major interpreted structural elements. The contour map indicates depth to the basement in meters. The Cretaceous nappe structures were overprinted by complex Neogene normal faulting. Note that members of the AG group dominate at the top of the basement. For details of transect A-A', see Figure IV.8.

Figure IV.8: West-northwest - east-southeast cross section of the Szeghalom Dome. The dashed lines indicate the separate paleo-fluid systems based on previous fluid inclusion results (Schubert et al., 2007). The Late Cretaceous nappe surfaces were cut by high angle Neogene normal faults. Significant storage capacity in the basement is exclusively related to amphibolite bodies in the AG group. The composition of the basement is unknown below the well A-22. The horizontal components of the cross section are not to scale. $\rightarrow$ 


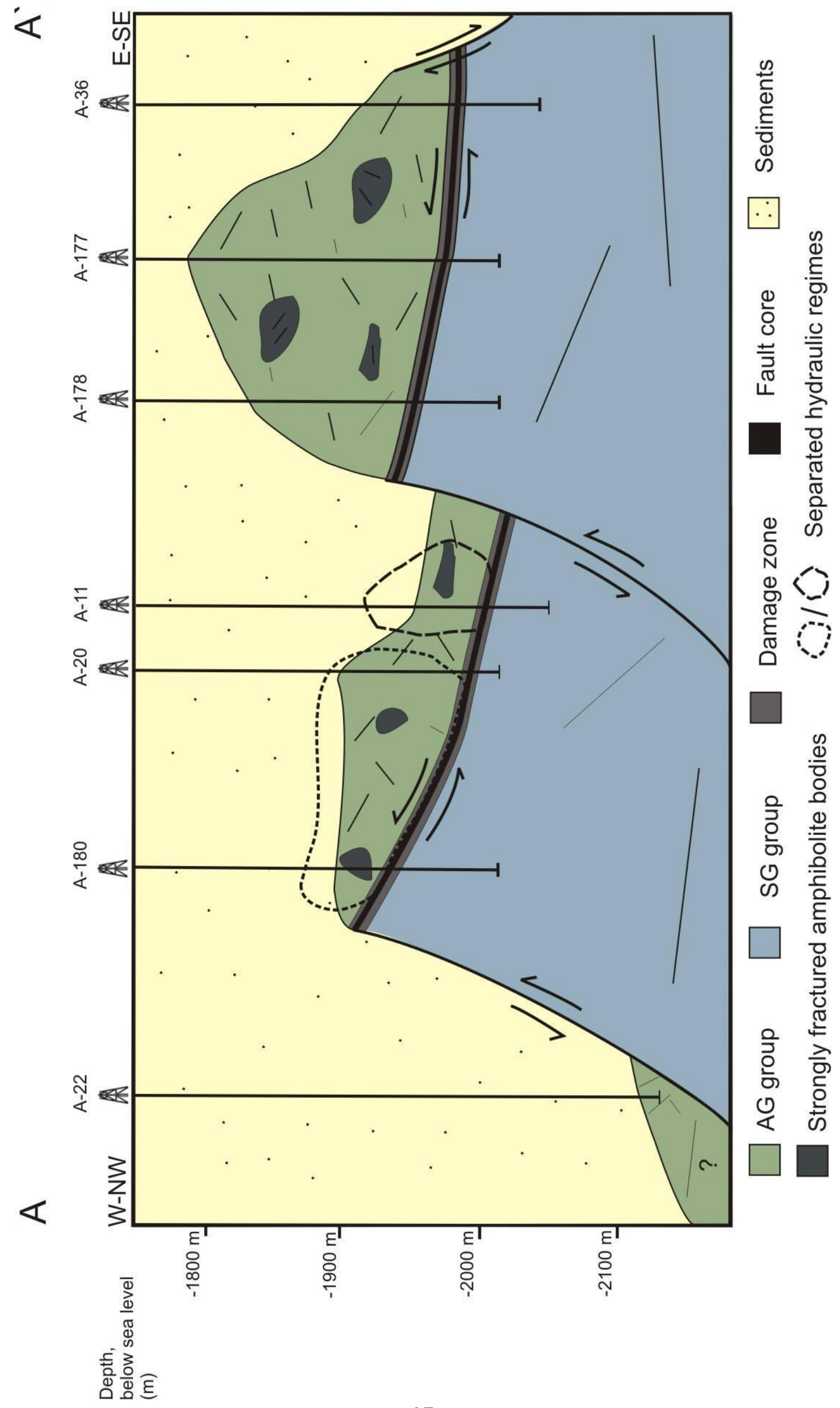


Extensional tectonic activity has been widely reported in the $\mathrm{SzD}$ and can be related to the formation of horst/graben structures during the syn-rift stage of the opening of the Pannonian Basin during the Miocene (M. Tóth, 2008). As a result of the complex evolution of the PB, this type of structure is most common in the central part of the basin; in contrast, the degree of extension at the basin margins was high enough to form metamorphic core complexes (Horváth et al., 2006). This phase of basin evolution culminated in the uplift and the exhumation of the SzD from a relatively shallow depth $(<10 \mathrm{~km})$ and the subsidence of nearby sub-basins (e.g., Békés Basin) (Teleki et al., 1994; M. Tóth, 2008).

\section{IV.6.3 Paleo-fluid regimes in the analyzed part of the $S_{z} D$}

In this section, the new structural data is integrated with the results of previous studies, particularly with respect to the hydrodynamic characteristics of the SzD (Fig. IV.8). M. Tóth et al. (2004) found that the densely fractured amphibolite bodies in the AG group contain significant storage capacity in the metamorphic blocks of the SzD.

The previously reconstructed paleo-fluid evolution was based on analyses of aqueous and petroleum inclusions in the fracture-filling quartz crystals, primarily from the amphibolites and subordinately from the damage zones of faults (Schubert, 2003; Schubert et al., 2007). The fact that most of the analyzed fluid inclusions are present in the amphibolite zones, while they are totally absent from the gneisses, strengthens the interpretation that the main storage capacity is related to the intensely fractured amphibolite bodies. In this model, the damage zones of brittle faults served as migration pathways towards the amphibolites, whose higher porosity was deduced from petrographical observations (coarse angular clasts with preserved pore space; c.f. Fig. IV.2.).

The geochemical features and the degree of maturation indicate that the petroleum fluids from wells A-180 and A-20 have similar characteristics, in contrast to well A-11, which contains 
significantly different (less mature and/or more intensely degraded) hydrocarbon fluids trapped in petroleum inclusions. No fluid inclusion data are available from wells A-22, -36, -177, and -178. The fluid inclusion data suggest that the rocks encountered in wells A-20 and A-180 form a connected paleo-hydrodynamic regime, while the rocks in well A-11 represent a separate fluid system, at least during the cementation of quartz in the fractures (Fig. IV.8). These data clearly indicate that even though these three wells are close to each other and they are aligned along the same, wide brittle shear zone (see Fig. IV.8), the rocks represent separate hydrodynamic regimes.

Several scenarios can explain the hydraulic compartmentalization of the SzD. An unlikely but possible scenario is related to the significant temporal/spatial variability in the density and porosity/permeability of the fracture network, which is probably caused by the cyclic cementation and reopening of fractures. In this scenario, the petroleum inclusions represent the stage of the evolution of the fracture network that was locally favorable for fluid inflow (after fracture opening/reopening), which was followed by cementation, fracture sealing and fluid inclusion entrapment. However, the spatial distribution of the open fractures at a particular time - and thus the favorable conditions for fluid inflow - was heterogeneous across the fracture network. This probably resulted in the local absence of entrapped hydrocarbon inclusions at a certain degree of maturity during the process of migration within the basement. As a result, this model implies the formation of temporarily separated hydraulic regimes, which provides a possible mechanism for the isolated fluid systems of the SzD. However, the absence of pervasive fracture propagation in diverse stress fields does not favor this theory.

Another possible scenario is compartmentalization due to the strong permeability anisotropy of the fault zones, which has been discussed by numerous authors (Evans et al., 1997; Zhang et al., 2001). Permeability anisotropy can be controlled by the shear displacement, effective stress, claysmearing along the fault plane or anisotropic microstructure (Géreaud et al., 2006). These papers revealed distinct differences in permeability with anisotropy ratios as high as $10^{4}$ (Evans et al., 1997). The highest values are parallel to the fault plane and to the slip direction $\left(\mathrm{K}_{(\mathrm{par} 1)}\right)$ (Fig. IV.9). 


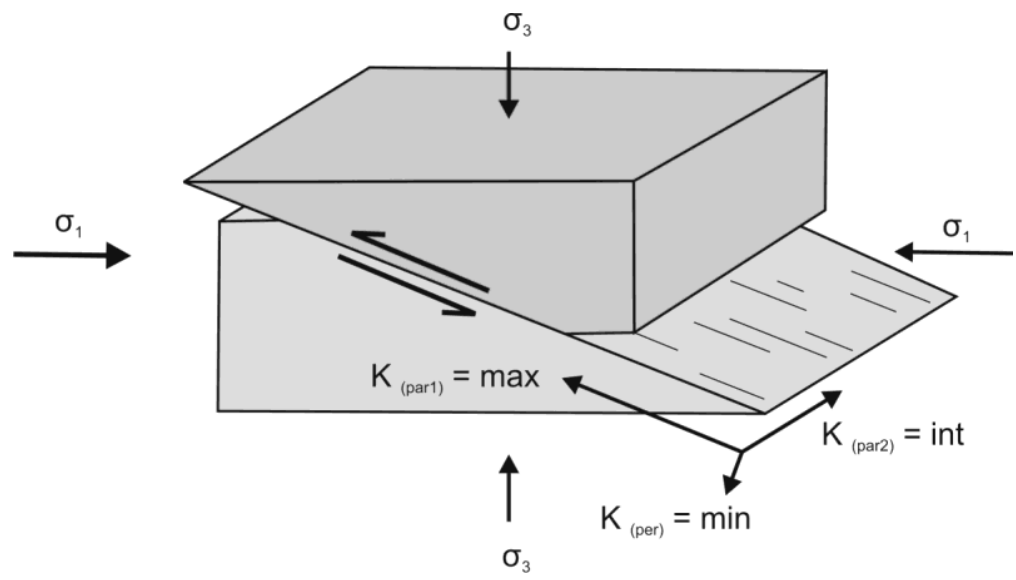

Figure IV.9: The permeability architecture of a thrust fault zone according to Evans et al. (1997). The highest permeability values occur parallel to the fault plane and parallel to the slip direction $\left(K_{(p a r l)}\right)$, and the lowest permeability values occur perpendicular to both the fault plane and the slip direction $\left(K_{(p e r)}\right)$. Transitional permeability values occur parallel to the fault plane and perpendicular to the slip direction $\left(K_{(p a r 2)}\right)$. These results indicate that the fault zone has a significant $\left(10^{4}\right)$ permeability anisotropy ratio.

The lowest permeability values are perpendicular to both the fault plane and the slip direction $\left(\mathrm{K}_{(\mathrm{per})}\right)$, while transitional values were reported parallel to the fault plane and perpendicular to the slip direction $\left(\mathrm{K}_{(\mathrm{par} 2)}\right)$. This strong anisotropy can lead to hydraulic separation along the strike of the major fault zone in the $\mathrm{SzD}$, as is observed in the different paleo-fluid characteristics in the neighboring A-11 and A-20 wells. Moreover, the maximum permeability along the dip of the fault zone can explain the connected paleohydraulic system encountered in wells A-20 and A-180 (Fig. IV.8).

The paleo-fluid regimes within the SzD could also have been fragmented due to the intense multistage tectonic activity in the Neogene (Lörincz, 1996). The interpreted structural architecture of the SzD supports this hypothesis. The normal faults probably disturbed the hydrocarbon migration in their vicinity (e.g., A-11, Fig. IV.7) and could have played a key role in the entrapment of the fluid inclusions with diverse chemical features (A-11 vs. A-20 and -180). It is difficult to determine whether these normal faults behaved as sealing faults or provided conduits for 
hydrocarbon migration towards the overlying clastic sediments. Nevertheless, the results of Juhász et al. (2002) on the hydraulic connection between the basement and the overlying sediment support the second hypothesis.

It is unclear if the paleo-fluid regime can be correlated with the recent hydrodynamic regimes. According to Schubert (2003) and Schubert et al. (2007), the paleo-fluid migration recorded by the HC-bearing fluid inclusions occurred between the Cretaceous and the Miocene. The onset of migration into the basement has been determined by biological marker compounds in the analyzed HC, whose source could not have been generated before the Cretaceous (Schubert, 2003). The data of Juhász et al. (2002) and Schubert et al. (2007) indicate that the paleo-fluid migration ended before the middle Miocene (Badenian) exhumation of the SzD.

In contrast, based on sedimentological and organic-geochemical evidence, the main sources of the hydrocarbons that are currently produced from the Szeghalom Dome basement reservoir are believed to be middle to upper Miocene shales (Teleki et al., 1994). Following the Badenian exhumation, the SzD formed an island in the Late Miocene Pannonian Lake. The basal conglomerate (Békés Formation) covered the coastal zones of the basement, while the local basinal clay marl aquitard (Endröd Formation) either overlaid the conglomerate or rested directly on the metamorphic domes (Fig. IV.10). This marl grades upward into a thick succession of turbidite-rich (Szolnok Formation) and delta front (Algyő Formation) sediments, which are thinner but coarser grained above the basement highs (Mátyás, 1994) and represent a possible pathway for vertical migration (Juhász et al., 2002) (Fig. IV.10). During the "post-rift" phase of the basin evolution, the exposed metamorphic highs subsided (“thermal subsidence”; Horváth et al., 1988; M. Tóth, 2008) to a depth of approximately 3 kilometers and provided pathways for fluid migration and/or storage (Juhász et al., 2002) (Fig. IV.10). Based on industry data (Teleki et al., 1994), the recently produced hydrocarbons of the SzD most likely originated from the adjacent overpressured sub-basins located south of the SzD, such as the Békés Basin and the Vésztő Graben, and were generated after the subsidence of the basin (Fig. IV.1). These data suggest some dissimilarity between the paleo- and 
the recent petroleum systems based on the possible source rocks.

In contrast, the results of the well-test data indicate several similarities between the paleoand recent fluid systems. In wells A-11 and A-36, the brecciated and intensely fractured damage zones of the thrust faults and the fracture system of the AG group have produced a significant amount of hydrocarbons (Fig. IV.6). Deeper water-producing intervals in A-180, A-20 and A-11 are also related to these permeable units but are below the oil-water contact. However, a well-test of well A-11 from the SG group did not show any inflow of fluid, indicating the impermeable nature of this lithologic unit. This implies that the same structural elements participated both in the past and current migration and entrapment processes. Because of the limited width and spatial distribution of the low-angle thrust faults, these zones of elevated transmissibility can only act as migration pathways within the reservoir. In contrast, the extensive amphibolite blocks of the AG group in the hanging wall presumably form the main reservoir rock of the basement petroleum system.

According to the model for the mechanism of the recent flow systems of Vass et al. (2009), the SzD has a very strong hydraulic connection with the overlying and juxtaposed sediments because the elevated blocks of metamorphic basement can drain the adjacent overpressured basins below the local aquitard (Endröd Formation) and have an important role in the compensation of their pressure conditions (Fig. IV.10). Due to its dense fracture network and numerous wide fault zones, the SzD behaves as a migration pathway towards the overlying clastic sediments (Szolnok and Algyő Formations); the relatively thin but rapid and notable fluid flux may have resulted in a so-called "chimney effect" in the internal parts of the crystalline rock body (Vass et al., 2009). The evaluation of the diagenetic history (Juhász et al., 2002) also demonstrated that the basement rocks and the overlying sediments must have been hydraulic connected since the Middle Miocene. This evidence underlines the importance of the intensely fractured parts of the AG group and the damage zones of the major fault zones in both the paleo- (based on fluid inclusion data) and recent (based on production data and modeling) hydrogeologic systems of the SzD despite the differences that 
were caused by the complex Neogene evolution of the SzD (Juhász et al., 2002; M. Tóth, 2008).

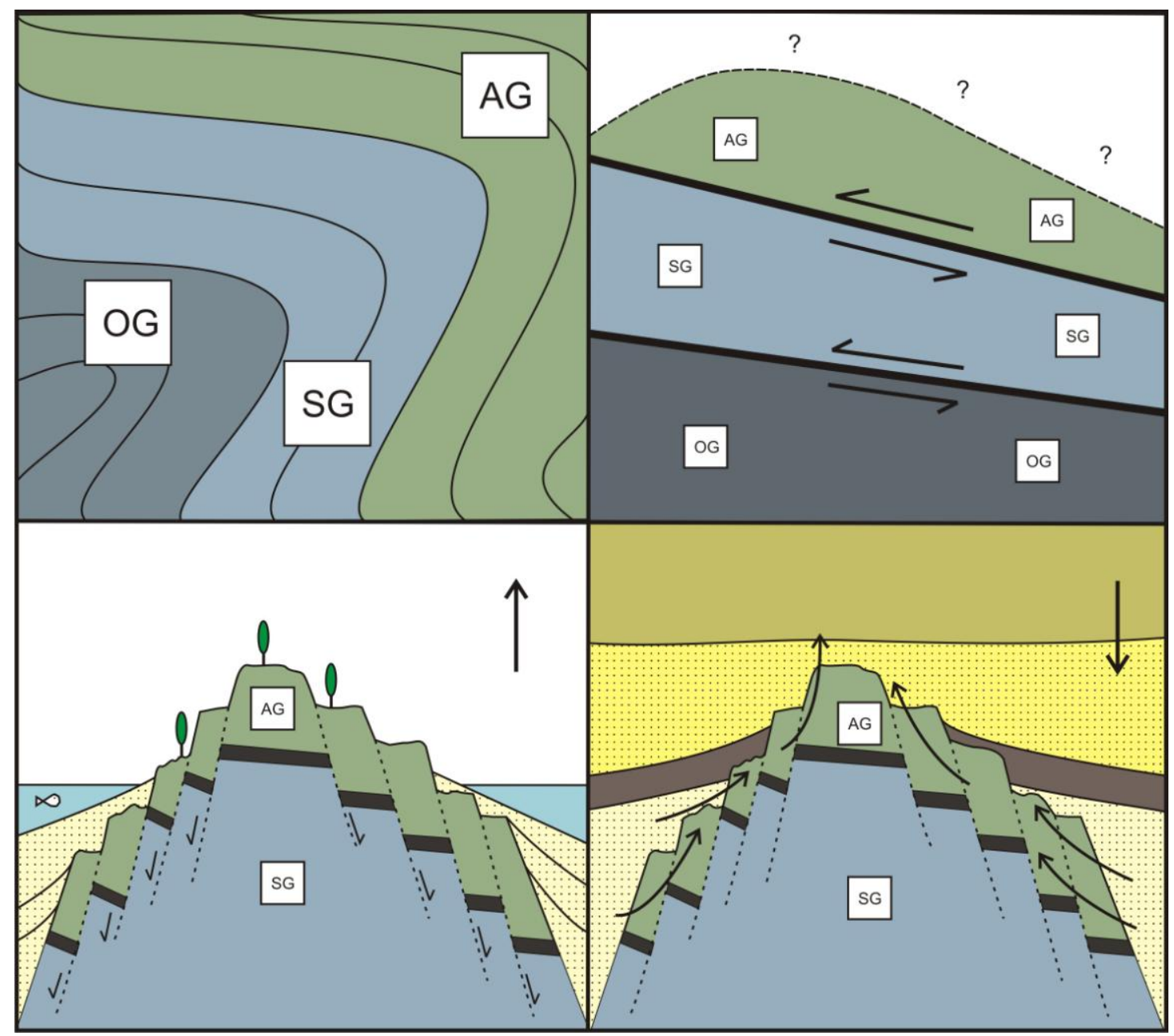

Figure IV.10: Schematic model of the geodynamic and hydrodynamic evolution of the Szeghalom Dome.

1: Coastal conglomerate (Békés Formation), 2: Basal clay marl, which forms a local aquitard (Endröd Formation), 3: Turbidite-rich sediments (Szolnok Formation), 4: Delta front sediments (Algyö Formation), 5: Main brittle fault zones, 6: Regional fluid flow system. a: Variscan multi-stage metamorphism of the lithologic groups at diverse pressure and temperature conditions. $b$ : Late Cretaceous nappe tectonics along low-angle thrust faults, which juxtaposed the AG, SG and OG lithologic groups. Deformation took place at shallow depths and with unknown overlying rocks. c: Middle Miocene (Badenian) exhumation of the $S_{z} D$ with the formation of a series of high-angle normal faults and the deposition of Pannonian clastic sediments. d: Recent hydraulic system of the SzD following Late Miocene subsidence of the area with significant overpressure under the local aquitard (Endröd Formation) and the evolution of the "chimney structure". The cross sections are not to scale. 


\section{IV.7 Conclusions}

In this study, we identified the master fault zones of the Szeghalom Dome, which is one of the largest fractured basement hydrocarbon reservoirs in the Pannonian Basin. According to previous investigations, these wide fault zones are mainly related to post-metamorphic tectonic events that juxtaposed incompatible lithologic types and possibly act as migration pathways because of their higher porosity and permeability. Based on integrated evaluations of core and well-log data, 1D lithologic columns of wells were defined and correlated spatially. The tectonized intervals were distinguished from the undeformed wallrock, and their internal lithologic structures (fault breccias, cataclasites, fault gouges) were defined to determine the significant components of these zones (damage zone versus fault core). We characterized the master faults as intervals consisting of distributed fault gouge zones.

The spatial arrangement of the fault zones indicates the presence of low angle thrust faults; based on the evolution of the Pannonian Basin, these faults were interpreted as indications of Cretaceous nappe activity. The structure of the Szeghalom Dome was further complicated by middle Miocene extension, which formed blocks in a horst-graben geometry and culminated in the exhumation of the metamorphic high.

These data of the structural evolution of the Szeghalom basement high were integrated with the results of previous investigations on the fracture network geometry, paleo-fluid evolution and recent production data. The results suggest that the amphibolite bodies have the highest storage capacity in the basement reservoir; the amphibolites are located exclusively within the AG lithologic group in the structurally highest basement locations. The strong chemical dissimilarities of the hydrocarbon-bearing fluid inclusions that are trapped in fracture-filling quartz veins can be explained by several theories but probably developed due to the significant permeability anisotropy 
in the fault zones that was derived from their complex architecture coupled with the effect of the Neogene structural evolution on the local flow systems.

A comparison of the paleo- and recent petroleum systems of the Szeghalom Dome revealed that the main difference was caused by the different source rocks of the hydrocarbons. The fault zones played a key role in the migration of the hydrocarbons from adjacent overpressured subbasins to both the amphibolite bodies with an interconnected fracture network and, since at least the middle Miocene, to the overlying clastic sediments. 


\section{Chapter V.: Conclusions}

\section{V.1 Summary of the results}

The previous chapters of the dissertation revealed some connections between the architecture and permeability structure of brittle fault zones, moreover, additional information gained on the rock mechanics and petrophysical properties of the fault rocks. Following these sections, the extension of the lithologic, petrophysical and rock-mechanical data emphasized the importance of brittle structural elements on hydraulic behaviour of the Szeghalom Dome. These results will be summarized in the next few pages.

In Chapter II the geometric aspects of the brittle deformation were defined on a thoroughly analyzed fault zone, which was penetrated by an important well with very high core recovery. Main deformational mechanisms were examined through the clast geometric features (Particle Size Distribution - "PSD”, Complexity - " $D{ }^{R}$ ”, Aspect Ratio - “AR”, Circularity - "Circ", Convexity "Conv" and Orientation - "Angle") of diverse, petrographically defined fault rock types, both in micro (thin section) and meso (borecore) scale. For the better understanding of the deformational processes, multivariate statistical methods were applied to reveal the connection between tectonites and their geometric parameters in diverse deformational stages. Discriminant functions defined the most characteristic geometric attributes of the tectonites and the classification pointed out relatively similar geometric nature of the breccias and the cataclasites, in contrast to the fault gouge category. Multidimensional scaling denoted a three-fold particle evolution scheme from the less deformed samples towards the most fragmented ones. This statistical interpretation displayed the strongly diverse attributes of the fault gouges in comparison to the other two groups.

In Chapter III, an attempt was taken to analyze the rock mechanical features of the borecores from a petrographically heterogeneous fault zone developed in a gneiss-dominant lithologic 
environment. The main fault zone components were defined by the microstructural observations and then these units were evaluated in a series of uniaxial compression tests. The damage zone was characterized as a quite brittle domain with low uniaxial compressive strength, contrary to the gouge-rich fault core, which reflects a strongly ductile nature and high uniaxial compressive strength. In the core of the fault zone, strain localization was the dominant phenomenon, as it was implied by the pervasive formation of fault gouge ribbons. Between the two main units of the shear zone an interesting section was defined with the manners of significant strain-hardening, relatively high uniaxial compressive strength and low brittleness. This transitional zone may suggest an interplay of the brittle and ductile behaviors and presumably mark the rock-mechanically strongest part of the fault zone. However, further works are required to decide whether it is a local or a general phenomenon in the fault zones of the crystalline rocks. Clast geometric discrimination of these fault rocks indicates the validity of the classification system introduced in Chapter II, at least on the metamorphic lithologies, based on the coincidence of clast geometric features with the petrographic observations.

In the first half of Chapter IV the available borecores were calibrated with their well-logs and the dominant petrophysical attributes were defined. The most essential factors in the difference between the undeformed wall rock and the tectonized zones are the high natural gamma values, the relatively lower electrical resistivity and the lower densities in the tectonized zones. The petrographic and well-log properties of different tectonite types defined the internal structure of the fault zones. According to function D3, higher level of deformation manifests in the increasing of the compensated neutron porosity values and further decreasing of the electric resistivity. In function D4, higher density and lower gamma values are characteristic. These suggest that the intensely deformed parts of the fault zones (cataclasites and fault gouges) can be characterized by the low density and resistivity and that the further elevated natural gamma activity and compensated neutron porosity values mark the fault core. In contrast, the interpreted damage zones with coarse fault breccias have higher density and resistivity values with lower gamma and neutron porosity 
values.

In the second half of Chapter IV, these calculated results were extended to the $1 \mathrm{D} \log$ intervals of the same well without borecores and their correlation was attempted with seven available wells from the Szeghalom field. It was known previously that the diverse metamorphic blocks (the orthogneiss dominated OG group, the high grade SG group, and the amphibolite rich AG group at the uppermost structural position) were juxtaposed via post-metamorphic tectonic activity. Only the densely fractured amphibolite bodies in the AG group contain significant storage capacity in the metamorphic blocks of the SzD, while fault zones are generally associated with higher conductivity and permeability relative to the undeformed wall rocks and define the main migrational pathways rhroughout the crystalline high. Spatial correlations between the reconstructed 1D lithologic columns revealed the main structural elements of the Szeghalom Dome.

The comminuted planes defined by the well-log properties - especially the clay-rich gouge zones - can act as the slip zones of the fault zones. Numerous weaker fragmented and thinner fault planes were also observed in the wells but did not contain cataclasite or gouge-bearing (slip) zones. These data suggest that the fault cores were the locations of the largest displacements and can be considered as major fault zones. Although the small amount of available information only allows a rough estimation on the geometry of the fault planes, and there is a slight difference in their dip angle and direction, these faults were likely affected by a similar deformational event. Earlier studies reported that the formation of these low angle $\left(\sim 5-15^{\circ}\right)$, northwest-vergent thrust sequences throughout the basement of the Pannonian Basin and the adjacent areas are related to the Eoalpine compressional activity during the late Cretaceous nappe formation (Pap et al., 1990, Teleki et al., 1994, Árkai et al., 1998, Tari et al., 1999, Kovács et al., 2000). According to this interpretation, AG and SG lithologic groups, with their distinct metamorphic pathways, were juxtaposed due to this Eoalpine compressional activity. The depth and exact age of the deformation is still unclear, as each zircon fission track datum from the vicinity of Szeghalom Dome have Jurassic age ( 187-160 Ma). These result are in coincidence with the youngest dominant $\mathrm{K} / \mathrm{Ar}$ and $\mathrm{Ar} / \mathrm{Ar}$ ages of the area $(\mathrm{K} / \mathrm{Ar}$ 
from feldspar: 195-180 Ma, Ar/Ar from feldspar: 157-145 Ma), which must be related to the continental rifting of the Tisza Megaunit (Balogh et al., 2009). The lack of zircon fission track or significant K/Ar, Ar/Ar ages following this heat event are an indirect evidence for shallow crustal (or even near surface) level of the tectonism during the Cretaceous.

Assuming the above dip of the thrust zone, the depths of the tectonized intervals in neighbouring wells indicate the presence of high angle normal faults with even 150 meters of vertical displacement in some cases. Extensional tectonic activity has been widely reported in the $\mathrm{SzD}$ and can be related to the formation of horst/graben structures during the syn-rift stage of the opening of the Pannonian Basin during the Miocene period (M. Tóth, 2008).

The paleofluid evolution was reconstructed based on analyses of aqueous and petroleum inclusions from the fracture-fillings of the amphibolites or the damage zones of faults (Schubert et al., 2007) and unpublished industrial (well test) data. The fact that most of the analyzed fluid inclusions are from the amphibolites and they are totally absent in the gneisses, indicate that the main storage capacity is related to the former lithology, strengthening the results of M. Tóth et al. (2004) on the fracture network geometry of SzD. The amphibolite-rich lithologies are dominant in the structurally topmost metamorphic block of the basement. In this model, the damage zones of faults with their limited width and spatial distribution served as migration pathways towards these sporadic bodies. The quite permeable behavior of the fault zones is underlined by the rather productive well-tests throughout the field.

The diverse fluid inclusion data (by the geochemical features and the degree of maturation of the analyzed hydrocarbons) indicate the presence of a compartmentalized hydrodynamic regime, at least during the cementation of the fractures. This separation can be explained most likely by the combined effects of the intense multistage Neogene tectonic activity (M. Tóth et al., 2009) and the strong permeability anisotropy of the fault zones (Evans et al., 1997).

There is dissimilarity between the paleo and recent petroleum systems of the SzD regarding the possible source rocks: the earliest date of paleo-fluid migration recorded by the fluid inclusions 
was the Cretaceous according to their biomarkers, while the data of Schubert et al. (2007) indicate that the migration ended before the Badenian exhumation of the SzD. In contrast, the currently produced hydrocarbon originated from upper Miocene shales in the adjacent sub-basins south from SzD (the Békés Basin or the Vésztő Graben, Teleki et al., 1994). In the light of the industrial data, SzD has a very strong hydraulic connection with the overlying sediments as the metamorphic basement can drain the adjacent over-pressured basins under regional aquitard (Endrőd Formation) and behaves as a migration pathway towards the overlying clastic sediments (Szolnok and Algyő Formation). Juhász et al. (2002) indicate the presence of the hydraulic connection between the basement and the overlying sediment since the middle Miocene period and the results defined in this work are in coincidence with the recent hydrodynamic observations.

\section{V.2 Outlook}

There are numerous still unanswered questions about the internal structure and the temporal evolution of both the brittle fault zones and the Szeghalom Dome itself, which require further detailed researches. Moreover, in the Pannonian Basin there are also several basement highs, where a puzzle of unrelated metamorphic blocks constitutes the basement (e.g., Jánoshalma - Zachar and M. Tóth 2004, Algyő - Lelkes-Felvári et al., 2003, Kiskunhalas - Fiser-Nagy et al., 2014) and these blocks were presumably juxtaposed by post-metamorphic tectonic movements. However, only limited information and data are available in publications and industrial reports for the reconstruction of their evolution. Nevertheless, a detailed investigation of their shear zones - like in the case of $\mathrm{SzD}$ - would provide essential information for the understanding their internal architectures.

Another potential way of investigations is the evaluation of the relationship between the observed deformational phases and their geochronological details. In Szeghalom, the age of the 
main events after the Variscan (Carboniferous) peak of the metamorphism ( $330 \mathrm{Ma})$ were defined by Balogh et al. (2009): this study separated a Permian metamorphism (K/Ar ages from biotite and amphibole and Ar/Ar ages from amphibole) and a Jurassic continental rifting event (K/Ar and $\mathrm{Ar} / \mathrm{Ar}$ ages from feldspar and zircon fission track). The reason for total lack of younger, late Mesosoic or Neogene ages requires a further analysis. For this purpose, especially age dating of the $<2 \mu \mathrm{m}$ fraction of the authogenic clay minerals of the fault rocks (e.g. K/Ar aging of the fault gouges) would be important.

The post-metamorphic tectonic events on Szeghalom Dome have caused wide tectonic zones and contributed to the development of the juxtaposed blocks with different metamorphic $P-T$ pathways. The role of these fault zones is quite various, since they theoretically may behave both as permeable and impermeable zones and may also act as migration pathways and/or barrier bodies. Hydrogeological interpretation of the unpublished borecore permeability measurements on the fault rocks of SzD may also provide useful information, as these test series revealed the strong tectonitetype controlled permeability structure of the brittle fault zones. The permeability measurements were completed on cylindrical shaped samples in a flexible wall permeameter (DW 250 Wille Geotechnik) with constant, 1.5 bar pressure. The fractured, brecciated damage zone samples own much higher permeability values (100-150 millidarcy), than the cataclastic or fault gouge-rich core zone, where the permeabilities vary between 1 and 5 millidarcy. These preliminary data prove the widely known two-faced hydraulic structure of the fault zones (Caine et al., 1996, Evans et al., 1997), where damage zone have a conduit feature, contrary to the fault core, which is usually a barrier for the fluid flow. Construction of a coherent fluid-flow model with the consideration of the defined lithologic structure of Szeghalom Dome may also offer a fruitful way of the further researches and can be a possible next step in the more detailed interpretation of the hydrodynamic behavior of the basement high.

Based on the unpublished industrial predictions, economically significant amount of still unproduced hydrocarbon can be trapped in these fractured highs. Accumulations in these Paleozoic 
highs often related to the structural elements with relatively simple setting (e.g., on the flanks of the basement highs adjacent to the Neogene sub-basins) (Bada and Tari, 2012), but past years developments in the seismic imaging techniques may now allow to discover more complex geometries within the basement. Additionally, the development of the seismic imaging techniques (e.g., determination of trapping or migrational configurations of the fault zones) can also promote the proper recognition of the role of fault zones in petroleum systems (Fossen, 2012).

All these possible ways of future work may largely contribute to a more sophisticated interpretation of the brittle fault zones and, moreover, may also provide remarkable results on the Szeghalom Dome or other basement highs in the Pannonian Basin. 


\section{Summary}

\section{Introduction, objectives}

Brittle fault zones are lithologically strongly heterogeneous structural elements and significantly affect the hydrogeological systems in the upper part of the Earth's crust. The structural and hydraulic features of the fault zones may reflect extreme temporal and spatial variation. Though, for instance, fault zones that are early in development may be permeable, they may become a barrier to fluid flow when they are more mature. The main fault components, as detailed by Caine et al. (1996) and Evans et al. (1997), are the fault core and the associated damage zone.

The basement of the Pannonian Basin contains several fractured metamorphic hydrocarbon reservoirs where the brittle deformation and the fault zones have a key role in the local hydrogeologic system. Békés Basin, the deepest sub-basin of the Pannonian Basin, is bordered by several Paleozoic highs that contain significant amounts of accumulated petroleum (e.g., the Dévaványa, Endrőd, Sarkadkeresztúr fields). One of the largest reservoirs the Szeghalom Dome is located on the northern margin of the Békés Basin and is mainly composed of Variscan gneisses and amphibolites with different metamorphic evolutions. These petrologically incompatible blocks were juxtaposed by post-metamorphic tectonic activity with predominantly Alpine or Neogene ages. This process was accompanied by the formation of brittle fault zones with notable porosity enhancement and as a result these planes mainly act as migrational pathways in the hydraulic system of the metamorphic highs.

Lithological composition for the Szeghalom Dome was summarized by M. Tóth (2008), along with the most characteristic lithologies (diverse types of gneisses, amphibolite and microgranite) and these results determined the conceptual lithological framework model of the basement high. Moreover, the post-metamorphic fluid and fracture network evolution was defined by Juhász 
et al. (2003) and Schubert et al. (2007) who described the possible timing of the petroleum migration and the details of hydraulic connectivity with the adjacent or overlying sedimentary rocks. Although these studies revealed the importance of the brittle fault zones in the juxtaposition of the diverse metamorphic blocks and subsequent fluid migration, no definition of their spatial arrangement has yet been achieved.

Aim of this study was to define the characteristics of the fault zones developed in metamorphic lithology with a special emphasis on their microstructural clast geometric and rock mechanical attributes. The throughout interpretation of the available borecores and well-log datasets aimed the determination of fault zones of the study area which provided the opportunity for the partial reconstruction of the post-metamorphic structural evolution of the Szeghalom Dome. Finally, discussing the relevance of the main shear zones in the petroleum system of the basement high was also a target of this work.

\section{Methods applied}

For the purpose of the classification of diverse fault rock samples from the fault zone of well A-180 in Szeghalom Dome detailed petrographic, macro- and microstructural investigations were carried out both on the available borecores and thin section.

The shape and size characteristics of the particles formed during brittle deformation were measured with Petrographic Image Analysis (PIA) method both in borecore and at the thin section scale. PIA of the borecore samples was performed on core-scanner pictures taken by the ImaGeo core scanner in the Hungarian Geological and Geophysical Institute. The micro-scale analysis was achieved on micro-photographs from selected, structurally representative parts of thin sections. The clast geometric measurements were completed using the selected parameters in ImageJ: Particle Size Distribution (PSD), Clast Complexity $\left(D^{R}\right)$, Aspect Ratio $(A R)$, Circularity (Circ), Convexity (Conv) and Clast Orientation (Angle). 
The resulted database allowed for statistical processing with the goal of distinguishing the distinct fault rocks and revealing the prevalent brittle deformation mechanisms that operate during different stages of fragmentation. IBM SPSS 20.0 Statistics software was applied for the statistical evaluation of the results to answer the following questions:

1) how reliably can the lithologies be distinguished based on their geometric parameters?

2) which parameters are responsible for characterisation of each group?

3) how do the different stages of deformation manifest in the measured parameters?

Discriminant function analyses were performed to define which parameters participate in the distinction of differ tectonite types, and to what level, both for pairwise and for all three groups. The aim of multidimensional-scaling is to set the place of the samples in the theoretical six-dimensional space of the measured parameters and illustrate the evolution of the particles from the aspect of geometric parameters.

Rock mechanical attributes of the fault rocks were determined using a series of uniaxial compressive tests according to the suggestions of the International Society for Rock Mechanics (ISRM, 2006). Rock mechanical tests were carried out in the Rock Mechanics Laboratory at the Budapest University of Technology and the Economics.

The well-log data were calibrated on the depth intervals of well A-180 that overlapped with the core samples to define the lithologic composition of seven analyzed well from the central part of the Szeghalom Dome. The data set was statistically evaluated using the IBM SPSS 20.0 statistics software. The discriminant function analysis method was constructed to separate the lithologic groups based on available potential, caliper, resistivity, density, compensated neutron porosity, acoustic and natural gamma logs. First, a discriminant function was computed to define the difference between the undeformed wall rock and the tectonized depth intervals by calculating the proper linear combination of the measured well-log data. Discriminant functions were then 
calculated to define the different types of fault rocks (fault breccia, cataclasite, fault gouge) within the zones that were classified as tectonized in the previous step. The computed functions were then applied to construct the lithological column of the investigated wells. Spatial correlations between the reconstructed 1D lithologic columns revealed the main structural elements of the Szeghalom Dome.

\section{New scientific results}

1. In the fault zone of the well A-180 three dominant fault rock types can be classified: fault breccias, cataclasites and fault gouges. Most of the analyzed samples were composed of coarse fault breccia that contained weakly disaggregated structures and clast sizes that were typically greater than $\mathrm{cm}$-scale. Several samples show characteristic micro-scale features of cataclastic deformation that resulted in a decrease in clast size an increase in the matrix ratio and the formation of preferred orientation. A third type of samples, the incohesive fault gouges, is present in thin deformational bands which probably define the localized slip zones of the faults.

2. The multivariate statistical processing of the clast geometric PIA results of the fault rocks demonstrated the importance of PSD, Angle, AR, and Circ parameters in the classification of diverse tectonite types. The calculated pair-wise and joint discriminant functions clearly separated the diverse fault rocks by the combination of the above parameters in descending order of importance. The discriminant functions also pointed out the relatively similar geometric features of fault breccias and cataclasites in contrast to the significantly different characteristics of fault gouges.

3. Multidimensional scaling resulted in a three-fold particle evolution scheme from the less deformed samples to the most fragmented ones. This statistical interpretation illuminated the strongly diverse attributes of the fault gouge compared with the other two groups of breccias and 
cataclasites. The multidimensional scaling demonstrated the evolution of the analysed brittle tectonites where the initial deformation is coupled with chaotic fabric giving a weakly disaggregated fault breccia texture. The transitional stage can be characterised by cataclastic flow while in the most deformed fault gouge samples the strong fragmentation, clast-rounding and oriented texture dominate.

4. The main fault zone units, the damage zone and the fault core were separated based on their rock mechanical features as a result of uniaxial compression tests series. Damage zone of the fault can be characterised by an extremely brittle nature and low uniaxial compressive strength coupled with a dominantly coarse fault breccia composition. In contrast, the gouge-rich fault core reflects a widespread plastic and inelastic nature with locally pseudo-ductile microstructure. In the core of the fault zone, strain localization was the dominant deformation phenomenon, as implied by the pervasive formation of fault gouge ribbons.

5. Between the damage zone and fault core units of the shear zone a characteristic section was observed based on the uniaxial compressive tests with significant strain hardening relatively high uniaxial compressive strength and low brittleness. This transitional zone may suggest interplay between the brittle and ductile behaviors and presumably marks the strongest part of the fault zone based on rock mechanics.

6. The available borecores were calibrated with their well logs, and the dominant petrophysical attributes of the tectonised depth intervals were defined. The most essential difference between the undeformed wall rock and the tectonized zones in this metamorphic lithology are the high natural gamma values, the relatively lower resistivity and densities in the tectonized zones. These results suggest that the intensely deformed fault cores can be characterized by the low density and resistivity with elevated natural gamma activity and compensated neutron porosity values. In 
contrast, the interpreted damage zones with coarse fault breccias have higher density and resistivity values with lower gamma and neutron porosity values. The calculated results were extended to the 1D log intervals of the same well without borecores and their correlation was attempted on the seven available wells from the Szeghalom field.

7. The estimated tectonic boundaries between the juxtaposed lithologic blocks of Szeghalom reservoir were defined via the correlation of the constructed 1D lithologic columns. According to their interpretation and to the structural evolution of the adjacent areas the spatial arrangement of the deformed depth intervals indicates the presence of low angle $\left(<15^{\circ}\right)$ thrust fault planes. These defined fault zones most likely developed due to north-northwest vergent Eoalpine (Late Cretaceous) compressional tectonics which was probably responsible for the juxtaposition of the different metamorphic blocks. The structure of the Szeghalom Dome was further complicated by high angle normal faults with approximately 100-150 meter of vertical displacement which are related to the middle Miocene extension. This phase of the geodynamical evolution of the basin is believed to be responsible for the horst-graben structure of the Szeghalom Dome.

8. The integration of the structural results with datasets of the paleo-fluid evolution recent production and fracture network geometry indicates the importance of these fault zones in both the migration of hydrocarbons from the adjacent sub-basins to the overlying sediments and to the strongly fractured amphibolite bodies within the basement. In this model, the damage zones of faults, with their limited width and spatial distribution served as migration pathways towards these sporadic bodies. The hydraulic compartmentalization of Szeghalom Dome can be explained most likely by the combined effects of the intense multistage Neogene tectonic activity (M. Tóth et al., 
2009) and the strong permeability anisotropy of the fault zones (Evans et al., 1997) throughout the fractured reservoir. 


\section{Összefoglalás}

\section{Bevezetés és célok}

A töréses vetőzónák rendkívül heterogén szerkezeti egységek, melyek jelentős hatással bírnak a felső kéreg hidrogeológiai rendszerére. Ezen zónák fő szerkezeti és hidraulikai vonása, hogy rendkívül jelentős idő- és térbeli változékonyságot mutatnak: például egyes, fejlödésük korai szakaszában permeábilis nyírási zónák, későbbi, „érett” fázisukban zárótestként viselkedhetnek. A vetőzónák gyakran jól meghatározható belső szerkezettel rendelkeznek, melynek legfontosabb részegységei elsősorban a Caine et al. (1996) és Evans et al. (1997) munkái alapján definiált „magzóna” illetve a kapcsolódó „kárzóna”.

A Pannon-medence kristályos aljzatában számos repedezett, metamorf szénhidrogén tározó található, melyek hidrogeológiai rendszerében a töréses vetőzónák kulcsszerepet játszanak. A terület legmélyebb süllyedékének, a Békés-medencének peremén számos ilyen repedezett aljzati tározó található, melyekben jelentős mennyiségü szénhidrogén halmozódott fel (például Dévaványa, Endrőd, Sarkadkeresztúr mezők). Közülük az egyik legjelentősebb a Szeghalom-dóm, mely a medence északi peremén helyezkedik el és javarészt különböző metamorf fokú variszkuszi gneiszekből és amfibolitokból épül fel. Ezen inkompatibilis kőzetblokkok a túlnyomórészt az alpi és neogén szerkezeti hatások eredményeként kerültek szomszédos helyzetbe, mely folyamat együtt járt széles töréses zónák kialakulásával. A gyakran jelentős porozitás növekedéssel járó folyamatnak eredményeként ezen zónák a metamorf hátak hidraulikai rendszerében migrációs útvonalat alkothatnak.

A Szeghalom-dóm felépítését M. Tóth (2008) összegezte, definiálva a terület legjellegzetesebb litológiai típusait (különböző gneisz, amfibolit és gránit típusok) illetve a kristályos-hát ideális kőzetoszlopát. Ezen túlmenően, Juhász et al. (2003) és Schubert et al. (2007) 
munkái összefoglalták a poszt-metamorf fluidum-evolúció föbb eseményeit, többek között meghatározva a szénhidrogén-migráció szakaszait és részletezve az aljzat és a szomszédos üledékes testek hidraulikai kapcsolatát. Mindazonáltal, bár ezen munkák kiemelték a töréses zónák jelentősségét a terület szerkezeti alakulásában és fluidum-migrációjában, nem definiálták ezen síkok pontos térbeli elrendeződését.

A dolgozat célja a metamorf kőzettestekben kialakult aljzati töréses zónák jellegzetességeinek meghatározása, különös tekintettel a mikroszerkezeti, klasztgeometriai és kőzetmechanikai tulajdonságokra. Ezeken túl, a rendelkezésre álló maganyag és lyukgeofizikai adatsorok részletes elemzésének célja a vizsgált terület vetőzónáinak azonosítása volt, mely lehetőséget teremtett a Szeghalom környéki aljzat kiemelkedés poszt-metamorf szerkezeti fejlődésének részleges rekonstruálására. Végül, de nem utolsó sorban a dolgozat vizsgálja a főbb nyírási zónák szerepét a kristályos aljzat szénhidrogén rendszerében.

\section{Alkalmazott módszerek}

A Szeghalom-dóm A-180-as fúrása által feltárt vetőzóna tektonit típusainak pontos meghatározásához a rendelkezésre álló magminták és vékonycsiszolatok alapos petrográfiai, makroés mikroszerkezeti vizsgálatát végeztem el.

A töréses deformáció hatására kialakult klasztok geometriai jellemzőinek méréséhez kőzettani képanalízist (Petrographic Image Analysis, PIA) alkalmaztam, mag és csiszolat léptékben egyaránt. A magminták feldolgozása magszkenner felvételek alapján történt, melyek a Magyar Földtani és Geofizikai Intézet Imageo magszkennerével készültek. A mikroléptékü elemzéshez a vizsgált vékonycsiszolatok szerkezetileg reprezentatív részeiről készült felvételeket használtam fel. A klasztgeometriai vizsgálatokhoz az ImageJ keretprogram alábbi paramétereit használtam fel: szemcseméret-eloszlás (Particle Size Distribution, PSD), szemcse bonyolultság (Clast Complexity, 
$D^{R}$ ), megnyúltság (Aspect Ratio, AR), cirkularitás (Circularity, Circ), konvexitás (Convexity, Conv) és szemcse-irányítottság (Clast Orientation, Angle).

A szemcsegeometriai eredmények nagyméretü adatbázisa lehetővé tette az adatok többváltozós statisztikai feldolgozását, melynek elsődleges célja a töréses deformáció során domináns mechanizmusok meghatározása volt. Az adatok IBM SPSS 20.0 Statistics szoftverrel történő elemzésével a következő kérdésekre igyekeztem választ keresni:

1) milyen biztonsággal különíthetőek el a tektonit típusok geometriai jellegzetességeik alapján?

2) mely paraméterek alkalmasak leginkább az egyes csoportok jellemzésére?

3) miként jelennek meg a különböző deformációs fázisok a paraméter értékek változásaiban?

Hogy megállapítást nyerjen, mely paraméterek és milyen mértékben vesznek részt a különböző tektonitok elkülönítésében, diszkriminancia függvényeket generáltam, mind csoport páronként, mind az összes csoportra együttesen. A többdimenziós skálázás célja a minták elhelyezése a mért paraméterek elméleti, hat dimenziós terében és a szemcsék geometriai fejlődésének ábrázolása volt.

A domináns kőzettípusok kőzetmechanikai jellegzetességeit egytengelyü töréstesztek eredményei alapján vizsgáltam, mely tesztek összhangban álltak a Nemzetközi Kőzetmechanikai Szövetség ajánlásaival (ISRM, 2006). A kísérletek a Budapesti Müszaki és Gazdaságtudományi Egyetem Közetmechanikai Laboratóriumában zajlottak.

A rendelkezésre álló hét, Szeghalom-dóm központi részéről származó kút lyukgeofizikai kalibrálása a maggal mintázott mélységintervallumok kőzettani értelmezése alapján történt, melyben kulcsfontossággal bírt az aljzatot közel 100\%-os magnyereséggel harántolt A-180-as fúrás. A karotázs adatsorok statisztikai alapú feldolgozásához ismételten IBM SPSS 20.0 Statistics szoftvert alkalmaztam. A diszkriminancia-függvény alapú litológiai elkülönítéshez a potenciál, lyukátmérő, ellenállás, sűrüség, neutron porozitás, akusztikus és természetes gamma szelvényeket 
használtam fel. Ennek első lépéseként a mért lyukgeofizikai paraméterek megfelelő lineáris kombinációjából számított függvényekkel elkülönítettem a deformálatlan falkőzet és deformált testek mélységszakaszait. Ezt követően az előző lépésben deformáltnak minősített intervallumok osztályozását végeztem el, különböző tektonitokhoz való hasonlóságuk alapján (breccsa, kataklázit, vetőagyag), meghatározva töréses zónák belső szerkezetét. A számított függvények a vizsgált kutak maggal nem ismert szakaszain történő alkalmazásával minden egyes kútra egy 1D-s litológiai oszlopot kaptam. A kutak közötti térbeli korreláció alapján meghatározhatóvá váltak az Szeghalomdóm vizsgált területének fő szerkezeti elemei.

\section{III. Új tudományos eredmények}

1. A Szeghalom-dóm A-180-as fúrása által feltárt széles nyírási zónában alapvetően három uralkodó tektonit típust különítettem el: vetőbreccsákat, kataklázitokat és vetőagyagokat. A minták jelentős hányada durva vetőbreccsa volt, melyek kismértékü elmozdulásra utaló kevéssé zúzott szerkezettel és uralkodóan centiméteres nagyságrendü szemcsemérettel rendelkeztek. Számos mintában a kataklázos deformáció jellegzetes mikroléptékű nyomait lehetett felfedezni, mint például az erőteljes szemcseméret csökkenés, a mátrixanyag arányának jelentős növekedése illetve a változó mértékü nyírási irányítottság megjelenése. A leginkább tektonizált kőzettípust a vetőagyagok alkották, melyek vékony szalagokként, elszórtan megjelenve a főbb elmozdulási síkokat alkotják.

2. A szemcsegeometriai PIA paraméterek többváltozós statisztikai feldolgozása rámutatott a szemcseméret-eloszlás (PSD), szemcse-irányítottság (Angle), megnyúltság $(A R)$, és cirkularitás (Circ) paraméterek fontosságára az egyes tektonit típusok osztályozásában. A csoportokat az azokra páronként és együttesen számított diszkriminancia függvények tisztán elkülönítették, mégpedig a fenti paraméterek felhasználásával. A függvények mindezek mellett hangsúlyozták a vetőbreccsa és 
kataklázit minták viszonylagos geometriai hasonlóságát, szemben a vetőagyagoknak definiált mintákkal.

3. A többdimenziós skálázás módszerével bizonyítottam, hogy a kevésbé deformált mintáktól a leginkább zúzottakig egy háromosztatú klaszt-fejlődési pálya határozható meg. A statisztikai módszer szintén rávilágított a vetőagyag minták egyedi morfológiai sajátosságaira. A vizsgálat első fejlődési szakaszaként a kezdeti deformációt határozta meg, ahol a kaotikus, irányítatlan szöveti képpel jellemezhető enyhén zúzott vetőbreccsák alakulnak ki. Az átmeneti fázisban a kataklázos folyás folyamata az uralkodó, míg a fejlődési pálya a vetőagyag minták esetén csúcsosodik ki, ahol az erős szemcseaprózódás, kerekítődés és az orientált szövet kialakulása jellemző.

4. A töréses vetőzónák fő szerkezeti elemeinek kőzetmechanikai tulajdonságait egytengelyü töréstesztek eredményei alapján határoztam meg. Ezek szerint a kárzóna extrém rideg testként jellemezhető az alacsony egytengelyü nyomószilárdság és breccsa-domináns összetétel mellett. Ezzel szemben a vetőagyagban gazdag magzóna rendkívül plasztikusan viselkedik, melyhez gyakran félképlékeny mikroszerkezeti bélyegek társulnak. Továbbá megállapítást nyert, hogy ebben a zónában gyakori jelenség volt a deformáció diszkrét síkokon történő koncentrálódása is, melyet az agyagos szalagok gyakori megjelenése is alátámaszt.

5. Az egytengelyü töréstesztek alapján egy jelentősen felkeményedő, magas nyomószilárdsággal és alacsony ridegségi mutatóval jellemezhető egységet határoztam meg a magzóna és a kárzóna határán. Ez az átmeneti szakasz feltehetően a töréses illetve képlékeny viselkedés kombinációjából alakulhatott ki és ennek eredményeként a nyírási zóna kőzetmechanikailag legellenállóbb zónájaként jellemezhető. 
6. A felhasználható magminták illetve azok mélységintervallumaihoz kapcsolódó lyukgeofizikai paraméterek összehangolását követően meghatároztam a tektonizált szakaszok kőzetfizikai tulajdonságait. A jelenleg vizsgált metamorf litológiai környezetben legjellegzetesebb eltérés a deformálatlan mellékkőzet és töréses szakaszok között utóbbiak magas gamma illetve viszonylag alacsonyabb ellenállás és sürüség értékeiben mutatkozott meg. Az eredmények rámutattak, hogy a legintenzívebben zúzott magzóna még alacsonyabb sürüség és ellenállás, illetve magas természetes gamma és neutron porozitás értékekkel jellemezhető. Ezzel szemben a kárzóna kevéssé zúzott szakaszain magasabb sürüség és ellenállás illetve alacsonyabb gamma és neutron porozitás értékek dominálnak. Következő lépésben, a kapott eredményeket kiterjesztettem a magmintákkal le nem fedett egydimenziós kútoszlopokra, a vizsgált kutak korrelációjának céljából.

7. A Szeghalom-dóm kőzettani blokkjait elválasztó tektonikus határok meghatározása a kutak 1D-s litológiai oszlopainak korrelációja alapján történt. A szomszédos területek szerkezeti fejlődése és a kialakított kőzetváz modell alapján a definiált vetősíkokat alacsony szögü $\left(<15^{\circ}\right)$ feltolódásokként értelmeztem. Ezen töréses zónák kialakulása és így az eltérő metamorf fejlődéstörténetü blokkok szomszédos pozícióba kerülése legnagyobb valószínüséggel a késő krétában lezajlott, északészaknyugati irányú, eoalpi kompressziós mozgásokhoz köthető. A Szeghalom környéki aljzat kiemelkedés szerkezetét tovább bonyolította a 100-150 méteres vertikális elmozdulással jellemezhető meredek normál vetők sorozata, melyek keletkezése feltehetően a középső-miocén extenziós tektonikai rezsimhez kapcsolódik. A Pannon-medence geodinamikai fejlődésének ezen szakasza okozhatta a vizsgált területen megfigyelhető árok-sasbérc szerkezetek kialakulását.

8. A szerkezetfejlődési eredmények illetve a rendelkezésre álló paleofluidum, termelési és repedésgeometriai adatok együttes értékelése rámutatott a töréses vetők megkerülhetetlen szerepére a szénhidrogén szomszédos mélymedencékből az aljzati háton keresztül a fedő üledékek felé történő migrációjában. Ezen túlmenően a deformált zónák szintén jelentős súllyal bírnak a 
metamorf háton belüli jól repedezett, elsősorban amfibolit testekbe történő áramlásban. A vázolt modell alapján, a vetők kárzónája korlátozott kiterjedése és térbeli előfordulása miatt elsősorban migrációs útvonalként viselkedik a jól repedezett kőzettestek irányába, mintsem aljzaton belüli tárolóként. A Szeghalom-dómon belüli szeparált hidrodinamikai alegységek kialakulása elsősorban a többfázisú neogén szerkezetfejlődésre (M. Tóth et al., 2009) és a töréses zónák okozta jelentős permeabilitás anizotrópiára (Evans et al., 1997) vezethető vissza. 


\section{Acknowledgement}

First of all, I would like express my gratitude for my supervisors, Tivadar M. Tóth and Félix Schubert for their valuable advices, suggestions and expertise in every way.

I have to say thank for all my colleagues at the Department of Mineralogy, Geochemistry and Petrology. MOL Hungarian Oil and Gas Company is thanked for providing the samples, datasets and the financial support of this research. I acknowledge the Institute of Geography and Geology, University of Szeged for their financial support granted through a pre-doctoral fellowship.

Balázs Kiss (MOL) is thanked for the fruitful discussions on the petroleum systems of the metamorphic basement highs and mechanisms of Szeghalom reservoir. I am grateful to Balázs Vásárhelyi for his support in the rock mechanical tests and advantageous suggestions on the interpretation of the results. Gyula Maros (Hungarian Geological and Geophysical Institute) is also thanked for his help in the use of ImaGeo corescanner.

Last, but not least, I am extremely grateful to Natália Szabó and my family for their continuous support and patience, which was essential for this work. 


\section{References}

Albu, I., A. Pápa, 1992: Application of high-resolution seismics in studying reservoir characteristics of hydrocarbon deposits in Hungary. Geophysics, 57, 8, 1068-1088.

Allan, U.S., 1989: Model for hydrocarbon migration and entrapment within faulted structures. AAPG Bulletin, 73, 803-811.

Antonellini, M., Aydin, A., 1995: Effect of faulting on fluid flow in porous sandstones: geometry and spatial distribution. AAPG Bulletin, 79, 642-671.

Árkai, P., Bérczi-Makk, A., Hajdu, D., 1998: Alpine prograde and retrograde metamorphisms in an overthrusted part of the basement, Great Plain, Pannonian Basin, Eastern Hungary. Acta Geologica Hungarica, 41, 179-210.

Aydin, A., 2000: Fractures, faults, and hydrocarbon entrapment, migration and flow. Marine and Petroleum Geology, 17, 797-814

Bada, G.., Tari, G.., 2012: Hungary. Exploration country focus. AAPG-European Newsletter, 2012, $6,5-8$.

Balázs, E., Cserepes-Meszéna, B., Nusszer, A., Szili-Gyémánt, P., 1986: An attempt to correlate the metamorphic formations of the Great Hungarian Plain and the Transylvanian Central Mountains (Muntii Apuseni). Acta Geologica Hungarica, 29, 3-4, 317-320. 
Balogh, K., M. Tóth, T., Dunkl, I., Scherrer, N., 2009: Gechronology of the polymetamorphic basement in the Szeghalom and Mezősas-Furta highs. In: M. Tóth, T. (ed.): Igneous and metamorphic rocks of the Tisza Unit. Szeged, Geolitera press, 147-160. (In Hungarian with English abstract)

Barnett, W., 2004: Subsidence breccias in kimberlite pipes - an application of fractal analysis. Lithos, 76, 299-316.

Becker, S.P., Eichhubl, P., Laubach, S.E., Reed, R.M., Lander, R.H., Bodnar R.J., 2010: A 48 my history of fracture opening, temperature, and fluid pressure: Cretaceous Travis Peak Formation, East Texas basin. Geological Society of America Bulletin, 122, 7-8, 1081-1093.

Ben-Zion, Y., Sammis, C.G.., 2003: Characterization of fault zones. Pure and Applied Geophysics, $160,677-715$.

Bérubé, D., Jébrak, M., 1999: High precision boundary fractal analysis for shape characterization. Computers \& Geosciences, 25, 1059-1071.

Biegel, R.L., Sammis, C.G.., Dieterich, J.H., 1989: The frictional properties of a simulated gouge having a fractal particle distribution. Journal of Structural Geology, 11, $827-846$.

Bieniawski, Z.T., 1967: Mechanism of brittle fracture of rock, parts I, II and III. International Journal of Rock Mechanics and Mining Sciences, 4, 395-430.

Billi, A., Salvini, F., Storti, F., 2003: The damage zone-fault core transition in carbonate rocks: implication for fault growth, structure and permeability. Journal of Structural Geology, 25, 1779- 
Billi, A., Storti, F., 2004: Fractal distribution of particle size in carbonate rocks from the core of a regional strike-slip fault zone. Tectonophysics, 384, 115-128.

Billi, A., 2007: On the extent of size range and power law scaling for particles on natural carbonate fault cores. Journal of Structural Geology, 20, 1512-1521.

Bistacchi, A., Massironi, M., and Menegon, L., 2010: Three-dimensional characterization of a crustal-scale fault zone: The Pusteria and Sprechenstein fault system (Eastern Alps). Journal of Structural Geology, 32, 2022-2041.

Blenkinsop, T. G.., 1991: Cataclasis and processes of particle size reduction. Pure and Applied Geophysics, 136, 59-86.

Brodie, K., Fettes, D., Harte, B., 2007: Structural terms including fault rock terms. In: Metamorphic rocks: a classification and glossary of terms, Cambridge University Press, 24-31.

Cai, M., Kaiser, P.,K., Tasaka, Y., Maejima, T., Morioka, H., Minami, M., 2004: Generalized crack initiation and crack damage stress thresholds of brittle rock masses near underground excavations. International Journal of Rock Mechanics and Mining Sciences, 41, 833-847.

Cai, M., 2010: Practical estimates of tensile strength and Hoek-Brown strength parameter of brittle rocks. Rock Mechanics and Rock Engineering, 43, 2, 167-184.

Caine, J.S., Evans, J.P., Forster, C.B., 1996: Fault zone architecture and permeability structure. 
Geology, 24, 1025-1028.

Caine, J.S., Ronald, L., Bruhn, R.L., Forster, C.B., 2010: Internal structure, fault rocks, and inferences regarding deformation, fluid flow, and mineralization in the seismogenic Stillwater normal fault, Dixie Valley, Nevada. Journal of Structural Geology, 32, 1576-1589.

Cattell, R.B., 1966: The scree test for the number of factors. Multivariate Behavioral Research, 1, 245-276.

Chester, F.M., Friedman, M., Logan, J.M., 1985: Foliated cataclasites. Tectonophysics, 111, 139146.

Clark, C., James, P., 2003: Hydrothermal brecciation due to fluid pressure fluctuations: examples from Olary Domain, Southwest Australia. Tectonophysics, 366, 187- 206.

Clark, C., Mumm, A.S., Collins, A.S., 2006: A coupled micro- and macrostructural approach to the analysis of fluid induced brecciation, Curnamona Province, South Australia, Journal of Structural Geology, 28, 745-761.

Cladouhos, T.T., 1999: Shape preferred orientations of survivor grains in fault gouge. Journal of Structural Geology, 21, 419-436.

Csontos, L., Nagymarosy, A., 1998: The Mid-Hungarian line: a zone of repeated tectonic inversions. Tectonophysics, 297, 51-71.

Cuong, T.X., Warren, J.K., 2009: Bach Ho field, a fractured granitic basement reservoir, Cuu Long 
Basin, SE Vietnam. Journal of Petroleum Geology, 32, 2, 129-156.

Czauner, B., Mádl-Szőnyi, J., 2013: Regional hydraulic behaviour of structural zones and sedimentological heterogeneities in an overpressured sedimentary basin. Marine and Petroleum Geology, 48, 260-274.

Dank, V., 1988: Petroleum geology of the Pannonian Basin, Hungary, an overview. In: Royden, L. and Horváth, F. (eds.): The Pannonian Basin. A study in basin evolution. AAPG Memoir, 45, 319331.

Davis, J.C., 2002: Statistics and Data Analysis in Geology. Wiley, 638

Engelder, J.T., 1974: Cataclasis and the generation of fault gouge. Geological Society of America Bulletin, 85, 1515-1522.

Evans, J.P., Forster, C.B., Goddard, J.V., 1997: Permeability of fault-related rocks and implications for fault-zone hydraulic structure. Journal of Structural Geology, 19, 1393-1404.

Faulkner, D.R., Jackson, C.A.L., Lunn, R.J., Schlische, R.W., Shipton, Z.K., Wibberley, C.A.J., Withjack, M.O., 2010: A review of recent developments concerning the structure, mechanics and fluid flow properties of fault zones. Journal of Structural Geology, 32,1557-1575.

Fiser-Nagy, Á., Varga-Tóth, I., M. Tóth, T., 2014: Lithology identification using open-hole well-log data in the metamorphic Kiskunhalas-NE hydrocarbon reservoir, South Hungary. Acta Geodaetica et Geophysica 49, 1, 57-78. 
Fossen, H., Schultz, R.A., Shipton, Z.K., Mair, K., 2007: Deformation bands in sandstone: a review. Journal of the Geological Society, 164.

Fossen, H., 2010: Structural geology. Cambridge University Press, 463.

Géraud, Y., Diraison, M., Orellana, N., 2006: Fault zone geometry of a mature active normal fault: A potential high permeability channel (Pirgaki fault, Corinth rift, Greece). Tectonophysics, 426, 6176.

Hausegger, S., Kurz, W., Rabitsch, R., Kiechl, E., Brosh, F. J., 2010: Analysis of the internal structure of a carbonate damage zone: Implications for the mechanisms of fault breccia formation and fluid flow. Journal of Structural Geology, 32, 1349-1362.

Hayman, N.,W., 2006: Shallow crustal fault rocks from the Black Mountain detachments, Death Valley, CA. Journal of Structural Geology, 28, 1767-1784.

Hecht, C.A., 2000: Appolonian packing and shape of grains improving geomechanical properties in engineering geology. Pure and Applied Geophysics, 157, 487-504.

Heilbronner, R., Keulen, N., 2006: Grain size and grain shape analysis of fault rocks. Tectonophysics, 427, 199-216.

Hirono, T., Sakaguchi, M., Otsuki, K., Sone, H., Fujimoto, K., Mishima, T., Lin, W., Tanikawa, W., Tanimizu, M., Soh, W., Yeh, E., Song, S., 2008: Characterization of slip zone associated with the 1999 Taiwan Chi-Chi earthquake: X-ray CT image analyses and microstructural observations of the Taiwan Chelungpu fault. Tectonophysics, 449, 63-84. 
Horváth, F., Dövényi, P., Szalay, Á., Royden, L.H., 1988: Subsidence, thermal and maturation history of the Great Hungarian Plain. In: Royden, L. H., Horváth, F. (eds.): The Pannonian Basin: A Study in Basin Evolution. AAPG Memoir, 43, 355-372.

Horváth, F., Tari, G.., 1999: IBS Pannonian Basin project: A review of the main results and their bearings on hydrocarbon exploration. In: Durand, B.,Jolivet, L., Horváth, F. and Seranne, M. (eds.): The Mediterranean basins: Tertiary extension within the Alpine orogen. Geological Society, London, Special Publications, 156, 195-213.

Horváth, F., Bada, G.., Szafián, P., Tari, G.., Ádám, Á., Cloething, S., 2006: Formation and deformation of the Pannonian basin: constraints from observational data. In: Gee, D.G.., Stephenson, R.A. (eds.): European Lithosphere Dynamics. Geological Society, London, Memoirs, 32, 191-206.

Hucka,V., Das, B., 1974: Brittleness determination of rocks by different methods. International Journal of Rock Mechanics and Mining Sciences, 11, 389-392.

Hung, J., Wu, Y., Yeh, E., Wu, J., 2007: Subsurface structure, physical properties, and fault zone characteristics in the scientific drill holes of Taiwan, Chelungpu-Fault Drilling Project. Terrestrial Atmospheric Oceanic Science, 18, 271-293.

ISRM, 2006: The complete ISRM suggested methods for rock characterization, testing and monitoring. International Society for Rock Mechanics, 628.

Jébrak, M., 1997: Hydrothermal breccias in vein-type ore deposits: a review of mechanisms, 
morphology and size distribution. Ore Geology Reviews, 12, $111-134$.

Jeppson, T.N., Bradbury, K.K., Evans, J.P., 2010: Geophysical properties within the San Andreas Fault Zone at the San Andreas Fault Observatory at Depth and their relationships to rock properties and fault zone structure. Journal of Geophysical Research,115.

Juhász, A., M. Tóth, T., Ramseyer, K., Matter, A., 2002: Connected fluid evolution in fractured crystalline basement and overlying sediments, Pannonian Basin, SE Hungary. Chemical Geology, $182,91-120$.

Kaye, B.H., 1989: A Random Walk Through Fractal Dimension. VCH Publishers.

Keulen, N., Heilbronner, R., Stünitz, H., Boullier, A.M., Ito, H., 2007: Grain size distributions of fault rocks: a comparison between experimentally and naturally deformed granitoids. Journal of Structural Geology, 29, 1282-1300.

Klovan, J.E., Billings, G.K., 1976: Classification of geological samples by discriminant function analysis. Bulletin of Canadian Petroleum Geology, 15, 313-330.

Kovács, S., Szederkényi, T., Haas, J., Buda, Gy., Császár, G.., Nagymarosy, A., 2000: Tectonostratigraphic terranes in the pre-Neogene basement of the Hungarian part of the Pannonian area. Acta Geologica Hungarica, 43, 225-328.

Lalonde, M., Tremblay, G., Jébrak, M., 2010: A Cellular Automata Breccia Simulator (CABS) and its application to rounding in hydrothermal breccias. Computers \& Geosciences, 36, 827-838. 
Laznicka, P., 1988: Breccias and coarse fragmentites. Petrology, environments, associations, ores. Developments in Economical Geology, 25.

Lee, H., Kim, H., 2005: Comparison of structural features of the fault zone developed at different protoliths: crystalline rocks and mudrock. Journal of Structural Geology, 27, 2099-2112.

Lelkes-Felvári Gy., Frank W., Schuster R., 2003: Geochronological constraints of the Variscan, Permian-Triassic and eo-Alpine (Cretaceous) evolution of the Great Hungarian Plain basement. Geologica Carpathica, 54, 5, 299-315.

Lin, A., 1999: S-C cataclasite in granitic rock. Tectonophysics, 304, 257-273.

Lonergan, L., Jolly, R.J.H., Rawnsley, K., Sanderson, D.J. (eds), 2007: Fractured Reservoirs. Geological Society, London, Special Publications, 270

Lörincz, K.D., 1996: Determination of stress-field history on the basis of multiphase tectonism identified in the seismic profiles, in the western part of the Szolnok flysch belt. Hungarian Geophysics, 37, 228-246. (in Hungarian with English abstract)

M. Tóth, T., Hollós, Cs., Szűcs, É., Schubert, F., 2004: Conceptual fracture network model of the crystalline basement of the Szeghalom Dome (Pannonian Basin, SE Hungary). Acta Geologica Hungarica, 47, 19-34.

M. Tóth T., Zachar J., 2006: Petrology and deformation history of the metamorphic basement in the Mezősas-Furta crystalline high (SE Hungary). Acta Geologica Hungarica, 49, 2, 165-188. 
M. Tóth, T., 2008: Repedezett, metamorf fluidumtárolók az Alföld aljzatában. DSc thesis. (In Hungarian)

M. Tóth, T., Redlerné, T.M., Kummer, I., 2009: Structural evolution of Szeghalom Dome on the basis of petrological and seismic data. Hungarian Geophysics, 29, 143-151. (In Hungarian with English abstract)

Manzocchi, T., Childs, C., Walsh, J.J., 2010: Faults and fault properties in hydrocarbon flow models. Geofluids, 10, 94-113.

Maros, Gy., Pásztor, Sz., 2001: New and oriented core evaluation method: ImaGeo. European Geologist, 12, 40-43.

Martin, C.,D.,1993: The strength of massive Lac du Bonnet granite around underground opening. $\mathrm{PhD}$ thesis, 278.

Matonti, C., Lamarche, J., Guglielmi, Y., Marié, L., 2012: Structural and petrophysical characterization of mixed conduit/seal fault zones in carbonates: Example from the Castellas fault (SE France). Journal of Structural Geology, 39, 103-121.

Mátyás, J., 1994: Diagenesis and porosity evolution of Neogene reservoir sandstones in the Pannonian Basin (southeast Hungary). PhD thesis , University of Bern, 196.

Moeller-Pedersen, P., Koestler, A.G.. (eds), 1997: Hydrocarbon Seals Importance for Exploration and Production. Norwegian Petroleum Society, Special Publications, 7. 
Mort, K., Woodcock, N.H., 2008: Quantifying fault breccia geometry: Dent Fault, NW England. Journal of Structural Geology, 30, 701-709.

Murray, A., Montgomery, D.W., 2012: Characterisation of highly fractured basement, Say’un Masila Basin, Yemen. In: Spence, G.H., Redfern, J., Aguilera, R., Bevan, T.G.., Cosgrove, J.W., Couples, G.D., Daniel, J.M. (eds): Advances in the Study of Fractured Reservoirs. Geological Society, London, Special Publications, 374.

Nelson, R.A., 2001: Geologic Analysis of Naturally Fractured Reservoirs. Gulf Publishing Company Book Division.

P’an, C.H., 1982: Petroleum in basement rocks. AAPG Bulletin, 66, 1597-1643.

Pap, S., 1990: Thrust-faulted sequences in Transtisia. Special Publications of the Hungarian Geological Survey; Budapest. (In Hungarian with English abstract)

Passchier, C.W., Trouw, R.A.J., 2005: Microtectonics, Springer.

Petford, N., McCaffrey, K.J.W., 2003: Hydrocarbons in Crystalline Rocks. Geological Society, London, Special Publication, 214.

Posgay, K., Bodoky, T., Hegedűs, E., Kovácsvölgyi, S., Lenkey, L., Szafián, P., Takács, E., Timár, Z., Varga, G.., 1995: Asthenospheric structure beneath a Neogene basin in southeast Hungary. In: Cloetingh, S., D'Argenio, B., Catalano, R., Horváth, F., Sassi, W. (eds): Interplay of extension and compression in basin formation. Tectonophysics, 252, 467-484. 
Salah, M.G., Alsharhan, A.S., 1996: Structural influence on hydrocarbon entrapment in the northwestern Red Sea, Egypt. AAPG Bulletin, 80, 1, 101-118.

Sammis, C.G., Osborne, R.H., Anderson, J.L., Banerdt, M., White, P., 1986: Self-similar cataclasis in the formation of fault gouge. Pure and Applied Geophysics, 124, 54-77.

Sammis, C.G.., King, G.., Biegel, R., 1987: The kinematics of gouge deformation. Pure and Applied Geophysics, 125, 777-812.

Schubert, F., 2003: Reconstruction of hydrocarbon-bearing fluid migration in the Szeghalom Dome (SE Hungary). PhD thesis, University of Szeged, 158. (in Hungarian)

Schubert, F., Diamond, L.W., M. Tóth, T., 2007: Fluid-inclusion evidence of petroleum migration through a buried metamorphic dome in the Pannonian Basin, Hungary. Chemical Geology , 244, $357-381$.

Sibson, R.H., 1977: Fault rocks and fault mechanisms. Journal of the Geological Society, 133, 191213.

Sibson, R.H., 1986: Brecciation processes in fault zones: inferences from earthquake rupturing. Pure and Applied Geophysics, 124, 159-174.

Storti, F., Billi, A., Salvini, F., 2003: Particle size distributions in natural carbonate fault rocks: insights for non-self similar cataclasis. Earth and Planetary Science Letters, 206, 173-186.

Storti, F., Balsamo, F., Salvini, F., 2007: Particle shape evolution in natural carbonate granular wear 
material. Terra Nova, 19, 344-352.

Storti, F., Balsamo, F., 2010: Impact of ephemeral cataclastic fabrics on laser diffraction particle size distribution analysis in loose carbonate fault breccia. Journal of Structural Geology, 32, 507522.

Stünitz, H., Keulen, N., Hirose, T., Heilbronner, R., 2010: Grain size distribution and microstructures of experimentally sheared granitoid gouge at coseismic slip rates - Criteria to distinguish seismic and aseismic faults? Journal of Structural Geology, 32, 59-69.

Szederkényi, T., Árkai, P., Lelkes-Felvári, Gy., 1991: Crystalline groundfloor of the Great Hungarian Plain and South Transdanubia. In: Karamata, S. (ed.): Geodynamic evolution of the Pannonian Basin, Beograd, 261-273.

Szili-Gyémánt, P., 1986: Metamorphic formations in Tiszántúl: The Körös-Berettyó and the Álmosd Units. Acta Geologica Hungarica, 29, 305-316.

Tari, G.., Horváth, F., Rumpler, J., 1992: Styles of extension in the Pannonian Basin: Tectonophysics, 208, 203-219.

Tari, G.., Dövényi, P., Dunkl, I., Horváth, F., Lenkey, L., Stefanescu, M., Szafián, P., Tóth, T., 1999: Lithospheric structure of the Pannonian basin derived from seismic, gravity and geothermal data. In: Durand, B., Jolivet, L., Horváth, F., Séranne, M. (eds.): The Mediterranean Basins: Tertiary Extension within the Alpine Orogen. Geological Society, London, Special Publications, 156, 215250. 
Tanaka, H., 1992: Cataclastic lineations. Journal of Structural Geology, 14, 1239-1252.

Teleki, P.G., Mattick, R.E., Kókai, J. (eds.), 1994: Basin Analysis in Petroleum Exploration. A Case Study from the Békés Basin, Hungary. Kluwer Academic Publishers.

Turcotte, D.L., 1986: Fractals and fragmentation. Journal of Geophysical Research, 91, 1921- 1926.

Vass, I., M. Tóth, T., Szanyi, J., Kovács, B., 2009: Water and heat flow through uplifted metamorphic highs in the basement of the Pannonian Basin, In: M. Tóth, T. (ed.): Igneous and metamorphic rocks of the Tisza Unit. Szeged, Geolitera press, 325-339 p. (In Hungarian with English abstract)

Wibberley, C.A.J., Shimamoto, T., 2003: Internal structure and permeability of major strike-slip fault zones: the Median Tectonic Line in Mie Prefecture, Southwest Japan. Journal of Structural Geology, 25, 59- 78 .

Wintsch, R.P., Christoffersen, R., Kronenberg A.K., 1995: Fluid-rock reaction weakening of fault zones. Journal of Geophysical Research, 100, B7, 13021-13032.

Woodcock, N.H., Dickson, J.A.D., Tarasewicz, J.P.T. 2007: Transient permeability and reseal hardening in fault zones: evidence from dilation breccia textures. In: Lonergan, L., Jolly, R.J.H., Rawnsley, K., Sanderson, D.J. (eds): Fractured Reservoirs. Geological Society, London, Special Publications, 270, 43-53.

Woodcock, N.H., Mort, K., 2008: Classification of fault breccias and related fault rocks. Geological Magazine, 145, 435-440. 
Zachar J., M. Tóth, T., 2004: Petrology of the metamorphic basement of the Tisza Block at the Jánoshalma High, S Hungary. Acta Geologica Hungarica, 47, 4, 349-371.

Zhang, S., Tullis, T., Scruggs, V., 2001: Implication of permeability and its anisotropy in a mica gouge for pore pressure in fault zones. Tectonophysics, 335, 37-50. 